\title{
Toms Pulmanis
}

\section{AR PUSAUDŽU PAŠNĀVNIECISKO UZVEDĪBU SAISTİTIE FAKTORI LATVIJĀ}

Promocijas darba kopsavilkums medicīnas doktora zinātniskā grāda iegūšanai Specialitāte - sabiedrības veselība un epidemioloǵija 


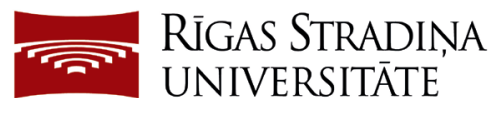

\author{
Toms Pulmanis
}

\title{
AR PUSAUDŽU PAŠNĀVNIECISKO \\ UZVEDĪBU SAISTĪTIE FAKTORI LATVIJĀ
}

\author{
Promocijas darba kopsavilkums \\ medicīnas doktora zinātniskā grāda iegūšanai
}

Specialitāte - sabiedrības veselība un epidemioloǵija

$$
\text { Rīga, } 2019
$$


Promocijas darbs izstrādāts Rīgas Stradiṇa universitātē.

Darba zinātniskais vadītājs:

Dr. med. profesors Māris Taube,

Rīgas Stradiṇa universitāte, Latvija

Oficiālie recenzenti:

Dr. med. asociētā profesore Ieva Strēle,

Rīgas Stradiṇa universitāte, Latvija

Dr. psych. profesore Sandra Sebre,

Latvijas Universitāte

$P h D$ Profesore Merike Sisask,

Tallinas Universitāte, Igaunija

Promocijas darba aizstāvēšana notiks 2019. gada 19. novembrī plkst. 13.00.

Rīgas Stradina universitātes Medicīnas promocijas padomes atklātā sēdē Rīgā, Dzirciema ielā 16, Hipokrāta auditorijā.

Ar promocijas darbu var iepazīties RSU bibliotēkā un RSU tīmekḷa vietnē: www.rsu.lv.

Promocijas padomes sekretāre:

Dr. med. asociētā profesore Inese Gobiņa 


\section{ANOTĀCIJA}

Ievads. Pašnāvības ir viena no būtiskākajām sabiedrības veselības problēmām Latvijā - pēc standartizētās mirstības rādītājiem Latvija ierindojas augstajā otrajā vietā ES dalībvalstu vidū. Būtisks pabeigtas pašnāvības riska faktors ir pašnāvnieciska uzvedība, t.sk. domas par pašnāvību un pašnāvības mēǵinājumi, kas iezīmē risku pabeigtai pašnāvībai, bieži tiek izmantota asociēto riska faktoru pētniecībā un ir īpaši aktuāla pusaudžu populācijās. Ar gimenes vidi saistîtajiem, vienaudžu vidi raksturojošajiem un individuālajiem faktoriem var būt nozīmīga loma saistībā ar pusaudžu pašnāvniecisko uzvedību, jo īpaši ņemot vērā faktu, ka vairāku šo faktoru izplatība Latvijā vērtējama kā augsta.

Darba mērḳis bija izpētīt pašu ziņotās pašnāvnieciskās uzvedības izplatību un saistību ar gimenes un vienaudžu vides raksturojošiem faktoriem, kā arī individuālajiem faktoriem 14-17 gadus vecu pusaudžu populācijā Latvijā.

Materiāls un metodes. Darbā izmantoti dati, kas iegūti reprezentatīvā šḳērsgriezuma pētījumā "Eiropas skolu aptaujas projekts par alkoholu un citām narkotiskajām vielām". Pētījuma instruments bija aprobēta, standartizēta aptaujas anketa. Kopumā promocijas darbā analizēti dati par 7299 respondentiem. Statistiskajā datu apstrādē izmantots biežumu sadalījums, šķērstabulas un Hī kvadrāta $\left(\chi^{2}\right)$ tests. Saistību noteikšanai izmantotas nesamērotās izredžu attiecības, Spīrmena korelācijas koeficients un daudzfaktoru loǵistiskā regresija.

Rezultāti. Domas par pašnāvību dzīves laikā atzīmējuši 15,7\% Latvijas 14-17 gadus veco pusaudžu - 11,7\% zēnu un 19,4\% meiteņu, bet pašnāvības mēǵinājumu dzīves laikā atzīmējuši 8,2\% pusaudžu - 5,9\% zēnu un 10,2\% meiteņu. Domu par pašnāvību izplatība ir augstāka to pusaudžu vidū, kuri savas 
ǵimenes materiālo stāvokli salīdzinājumā ar citām ǵimenēm Latvijā vērtē kā sliktāku - meiteṇu vidū šādi vērtēta gimenes materiālā stāvokḷa gadījumā vērojama arī augstāka pašnāvības mēǵinājumu izplatība.

Ar ǵimenes vidi saistītie faktori, kas neatkarīgi paaugstina izredzes domām par pašnāvību abās dzimumu grupās ir pašnāvnieciska pieredze ǵimenē, fiziska vardarbība ğimenē, reti/nekad un dažreiz izjusts vecāku emocionālais atbalsts, bet atsevišķi zēniem - nedzīvošana ar abiem biologiskajiem vecākiem. Ar ǵimenes vidi saistītie faktori, kas neatkarīgi paaugstina izredzes pašnāvības mēginājumam abās dzimumu grupās ir pašnāvnieciska pieredze ǵimenē, fiziska vardarbība gimenē, reti/nekad izjusts vecāku emocionālais atbalsts un nedzīvošana ar abiem biologiskajiem vecākiem, bet atsevišķi zēniem - seksuāla uzmākšanās ğimenē un atsevišḳi meitenēm - dažreiz izjusts vecāku emocionālais atbalsts.

Ar vienaudžu vidi saistītie faktori, kas neatkarīgi paaugstina izredzes domām par pašnāvību abās dzimumu grupās ir pašnāvnieciska pieredze vienaudžu vidū, vienmēr/bieži un dažreiz piedzīvota ņirgāšanās skolā, bet atsevišḳi meitenēm - reti/nekad un dažreiz izjusts vienaudžu emocionālais atbalsts. Ar vienaudžu vidi saistītie faktori, kas neatkarīgi paaugstina izredzes pašnāvības mēǵinājumam abās dzimumu grupās ir pašnāvnieciska pieredze vienaudžu vidū, vienmēr/bieži un dažreiz piedzīvota ņirgāšanās skolā, bet atsevišḳi meitenēm - reti/nekad izjusts vienaudžu emocionālais atbalsts.

Individuālie faktori, kas neatkarīgi paaugstina izredzes domām par pašnāvību abās dzimumu grupās ir augsts un vidēji augsts depresijas simptomu līmenis, zems un vidēji zems pašcieņas līmenis, narkotiku lietošana dzīves laikā un ikdienas smēkēšana, bet atsevišķi meitenēm - neapmierinātība un vidēja apmierinātība ar savu veselības stāvokli, kā arī riskanta alkohola lietošana dzīves laikā. Individuālie faktori, kas neatkarīgi paaugstina izredzes pašnāvības mēǵinājumam abās dzimumu grupās ir augsts un vidēji augsts depresijas 
simptomu līmenis, zems un vidēji zems pašcieņas līmenis, ikdienas smēḳēšana un neapmierinātība ar savu veselības stāvokli, atsevišķi meitenēm - riskanta alkohola lietošana dzīves laikāa, bet atsevišḳi zēniem - narkotiku lietošana dzīves laikā. 


\section{SATURA RĀDĪTĀJS}

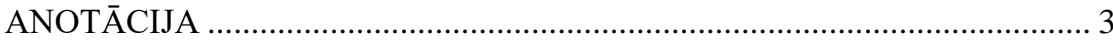

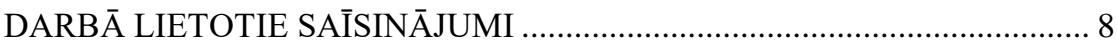

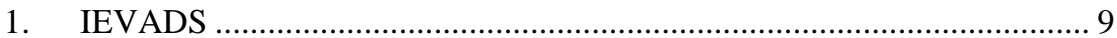

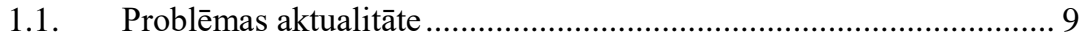

1.2. Promocijas darba mērkis................................................................ 11

1.3. Promocijas darba uzdevumi ......................................................... 11

1.4. Promocijas darba hipotēzes......................................................... 12

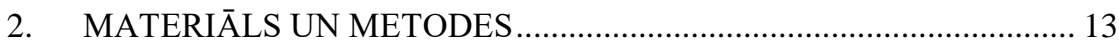

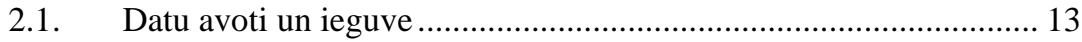

2.2. Pētāmo mainīgo pazīmes un grupēšana ........................................... 13

2.3. Pētāmās populācijas raksturojums .................................................... 20

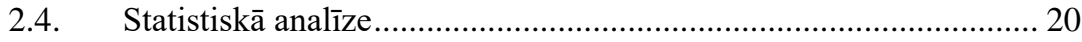

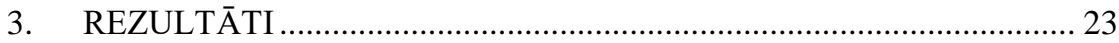

3.1. Pašnāvnieciskā uzvedība sociāldemogrāfiskajās grupās.................. 23

3.2. Pašnāvnieciskās uzvedības savstarpējā saistība .............................. 24

3.3. Pašnāvnieciskā uzvedība un ar ğimenes vidi saistītie faktori ......... 25

3.4. Pašnāvnieciskā uzvedība un ar vienaudžu vidi saistītie faktori ...... 32

3.5. Pašnāvnieciskā uzvedība un individuālie faktori ............................. 38

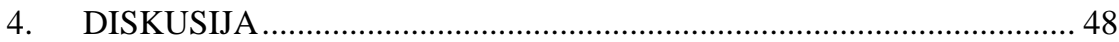

4.1. Pašnāvnieciskās uzvedības izplatība pusaudžu sociāldemogrāfiskajās

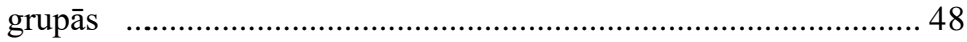

4.2. Pašnāvnieciskā uzvedība un ar ğimenes vidi saistītie faktori ......... 52

4.3. Pašnāvnieciskā uzvedība un ar vienaudžu vidi saistīitie faktori ...... 56

4.4. Pašnāvnieciskā uzvedība un individuālie faktori ............................. 59

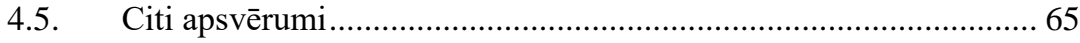

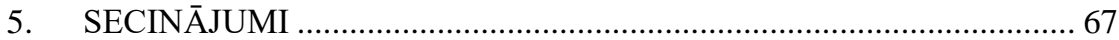




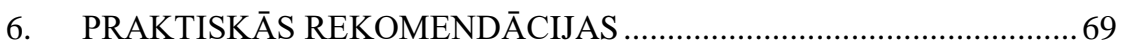

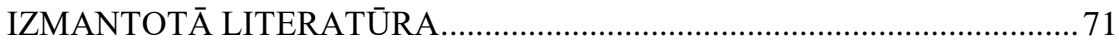

PUBLIKĀCIJAS UN TĒZES PAR DARBA TĒMU .....................................79

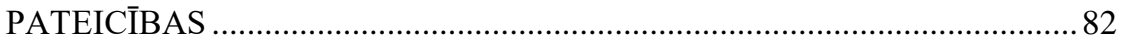




\section{DARBĀ LIETOTIE SAĪSINĀJUMI}

CES-D Epidemiologisko pētîjumu centra Depresijas skala (Centre for Epidemiological Studies Depression Scale)

ES Eiropas Savienība

ESPAD Eiropas skolu aptaujas projekts par alkoholu un citām narkotiskajām vielām (European School Survey Project on Alcohol and Other Drugs)

IZM Izglītības un zinātnes ministrija

OR izredžu attiecība (odds ratio)

PVO Pasaules Veselības organizācija

VIF dispersijas inflācijas faktors (variance inflation factor) 


\section{IEVADS}

\subsection{Problēmas aktualitāte}

Pašnāvības bija un ir sabiedrības veselības problēma, kas cilvēkiem priekšlaicīgi atṇem dzīvību, dramatiski ietekmē pašnāvībās mirušo ǵimenes un līdzcilvēku dzìves, kā arī rada ekonomiskos zaudējumus valstīm kopumā (World Health Organization [WHO], 2014a; Zhang, Tong and Zhou, 2005; Kinchin and Doran, 2018).

Mirstība no pašnāvībām Eiropas reǵionā, salīdzinot ar citiem reǵioniem, ir augsta - deviņas valstis ar augstāko mirstību no pašnāvībām pasaulē atrodas tieši šajā reǵionā, vairākās valstīs biežākais pusaudžu nāves cēlonis ir pašnāvība (WHO, 2015).

Pasaulē pašnāvībās ik gadu mirst teju 800000 cilvēku, un tas ir viens pašnāvības upuris katrās 40 sekundēs. Globāli pašnāvība ir otrais biežākais nāves cēlonis 15-29 gadu vecuma grupā. Vēl ievērojami lielāks ir to cilvēku skaits, kas izdara pašnāvības mēgininājumus (WHO, 2018a).

Pašnāvības ir viena no būtiskākajām sabiedrības veselības problēmām arī Latvijā - pēc standartizētās mirstības rādītājiem kopējā Latvijas populācija ierindojas otrajā augstākajā vietā ES dalībvalstu vidū (Šica, Pulmanis un Taube, 2017), savukārt 15-19 gadus veci pusaudži - septītajā (Eurostat, 2018). Visvairāk potenciālo mūža gadu Latvijā tiek zaudēti ārējo nāves cēloṇu dēḷ, starp kuriem līderpozīcijās ir tieši pašnāvības (Štāle, Treide un Rožkalne, 2016; Skrule, 2014).

Pašnāvību un pašnāvnieciskās uzvedības problēmas aktualitāte ir skaidri uzsvērta Latvijas Sabiedrības veselības pamatnostādnēs 2014.-2020. gadam, kur minēts: "N̦emot vērā augstos pašnāvību rādītājus, gan bērnu, gan pieaugušo pašnāvību un pašnāvnieciskās uzvedības profilakse jāuzskata par vienu no sabiedrības veselības prioritātēm Latvijā”’ (LR Ministru kabinets, 2014). 
Problēmas aktualitāte gan populācijā kopumā, gan jaunu cilvēku un pusaudžu vidū uzsvērta arī vairākos starptautiska līmeņa politikas plānošanas dokumentos, tajā skaitā PVO Psihiskās veselības rīcības plānā 2013.-2020. gadam (angl. - Mental Health Action Plan 2013-2020) (WHO, 2013) un PVO Eiropas psihiskās veselības rīcības plānā 2013.-2020. gadam (angl. - The European Mental Health Action Plan 2013-2020) (WHO, 2015).

Pašnāvnieciska uzvedība - domas par pašnāvību, pašnāvības mēǵinājumi u. c. saistās ar dažāda līmeņa risku pabeigtai pašnāvībai un bieži tiek analizēta asociēto riska faktoru pētniecībā (Bridge, Goldstein and Brent, 2006). Zinātniskajā literatūrā nevalda vienprātība par pašnāvnieciskās uzvedības (angl. - suicidal behavior) definīciju un ir vērojamas dažādas pieejas (Goodfellow, Kõlves and De Leo, 2018; De Leo et al., 2006; WHO, 2014b). Definīcijas izteikti variē, mēdz būt neprecīzas un mainīgas, jo īpaši kad runa ir par pašnāvniecisku uzvedību bez letāla iznākuma un domām par pašnāvību.

Pašnāvnieciska uzvedība ir izplatītāka pusaudžu vidū, ar plaša spektra riska faktoriem. Šo faktoru identificēšana un katra faktora lomas un ietekmes izpēte ir nozīmīgs jautājums pašnāvību profilaksē (Krug et al., 2002).

Ārvalstīs veiktu pētījumu dati liecina, ka ietekme uz pusaudža psihoemocionālo labklājīibu var būt vairākiem ar gimenes un vienaudžu vidi saistītajiem, kā arī pusaudža individuālajiem faktoriem, piemēram, ciešas un savstarpēji atbalstošas attiecības ǵimenē ir saistītas ar labāku psihisko veselību (Rothon, Goodwin and Stansfield, 2012), vecāku atbalsts var aizsargāt bērnu nelabvēlīgā, vardarbīgā vidē (Stadler et al., 2010; Wallen and Rubin, 1997), drošības un piederības sajūta var mazināt riska uzvedību (Brooks et al., 2012), pusaudži no emocionāli atbalstošas vienaudžu vides ir ar augstāku psihoemocionālo labklājību, šiem pusaudžiem ir augstāka sociālā kompetence, kā arī mazāk emocionālo un uzvedības problēmu (WHO, 2016; Kerr et al., 2003; Colarossi and Eccles, 2003; Lenzi et al., 2012). 
Īpaši aktuālu dažādu pašnāvnieciskās uzvedības riska faktoru potenciālās ietekmes analīzes nepieciešamību Latvijā padara augstais dažādu ar pašnāvniecisko uzvedību potenciāli saistīto faktoru izplatības līmenis Latvijas bērnu un pusaudžu populācijāa, piemēram, vardarbība ǵimenē (Velika u. c., 2012), vienaudžu vardarbība, emocionālā atbalsta trūkums (WHO, 2016), atkarību izraisošo vielu lietošana (Sniķere un Trapencieris, 2016) u. c.

Neskatoties uz augstajiem pašnāvību rādītājiem Latvijā un faktu, ka šobrīd jau aptuveni trešdạ̣ā pasaules valstu ar vidēju un augstu ienākumu līmeni ir izstrādātas un pieņemtas atsevišķas pašnāvību profilakses stratēgijas (WHO, 2018b), Latvijā pašnāvnieciskās uzvedības un ar to saistīto riska faktoru pētniecība, jo īpaši, bērnu un pusaudžu vidū līdz šim vērtējama kā ierobežota un nepietiekama.

Lai īstenotu uz pierādījumiem balstītas pašnāvību un pašnāvnieciskās uzvedības profilakses programmas gan populācijā kopumā, gan riska grupās, pēc iespējas precīzākai intervenču definēšanai un mērķēšanai caur padziḷinātu pētniecību ir nepieciešams iegūt uz pierādījumiem balstītas zināšanas specifiski par Latvijas pusaudžiem.

\subsection{Promocijas darba mērķis}

Darba mērḳis ir izpētīt pašu ziņotās pašnāvnieciskās uzvedības izplatību un saistību ar ǵimenes un vienaudžu vidi raksturojošiem faktoriem, kā arī individuālajiem faktoriem 14-17 gadus vecu pusaudžu populācijā Latvijā.

\subsection{Promocijas darba uzdevumi}

1. Noskaidrot domu par pašnāvību un pašnāvības mēǵinājumu izplatību pusaudžu sociāldemogrāfiskajās grupās Latvijā. 
2. Analizēt pusaudžu domu par pašnāvību un pašnāvības mēǵinājumu dzimimspecifisko saistību ar gimenes vidi raksturojošiem faktoriem nedzīvošanu ar abiem bioloǵiskajiem vecākiem, emocionālā atbalsta trūkumu no vecākiem, pašnāvniecisku pieredzi gimenē, fizisku vardarbību gímenē un seksuālu uzmākšanos ǵimenē.

3. Analizēt pusaudžu domu par pašnāvību un pašnāvības mēǵinājumu dzimumspecifisko saistību ar vienaudžu vidi raksturojošiem faktoriem emocionālā atbalsta trūkumu no vienaudžiem, pašnāvniecisku pieredzi vienaudžu vidū un vienaudžu ņirgāšanos skolā.

4. Analizēt pusaudžu domu par pašnāvību un pašnāvības mēǵinājumu dzimumspecifisko saistību ar individuālajiem faktoriem - depresijas simptomu līmeni, pašcieņas līmeni, veselības pašvērtējumu, riskantu alkohola lietošanu, ikdienas smēḳēšanu un narkotiku lietošanu.

5. Sniegt promocijas darba secinājumos balstītas rekomendācijas intervencēm pašnāvnieciskās uzvedības profilaksei 14-17 gadus vecu pusaudžu populācijā Latvijā un nākotnē īstenojamai pētniecībai pusaudžu pašnāvnieciskās uzvedības jomā.

\subsection{Promocijas darba hipotēzes}

1. Abu dzimumu grupās pastāv saistība starp pusaudžu pašu ziņotajām domām par pašnāvību un visiem pētītajiem ar gimenes vidi saistītajiem, vienaudžu vidi raksturojošajiem un individuālajiem faktoriem.

2. Abu dzimumu grupās pastāv saistība starp pusaudžu pašu ziņotajiem pašnāvības mēgéinājumiem un visiem pētītajiem ar ǵimenes vidi saistītajiem, vienaudžu vidi raksturojošajiem un individuālajiem faktoriem. 


\section{MATERIĀLS UN METODES}

\subsection{Datu avoti un ieguve}

Promocijas darba izstrādē izmantoti pēc starptautiski vienotas metodolog̣ijas iegūti Latvijas dati no Slimību un profilakses kontroles centra 2011. gada Eiropas skolu aptaujas projekta par alkoholu un citām narkotiskajām vielām (angl. - European School Survey Project on Alcohol and Other Drugs) (ESPAD).

Pētījuma instruments bija aprobēta, standartizēta aptaujas anketa latviešu un krievu valodās. Aptaujas anketā tika koriǵēti atsevišķi jautājumi, kuri tika validēti divās fokusa grupas diskusijās ar mērḳa grupas pusaudžiem pirms pētījuma lauka darba uzsākšanas. Tāpat aptaujā izmantoti atsevišķi papildus jautājumu moduḷi (t. sk. psihosociālais modulis) (Trapencieris u. c., 2012). Promocijas darbā izmantoti gan starptautiski standartizētie jautājumi, gan specifiski Latvijas pusaudžiem uzdoti jautājumi, kuru izstrādē piedalījies arī promocijas darba autors.

Pētîjuma dalībnieku atlasei tika izmantota stratificēta klāsteru gadījumizlase, kurā kā izlases pamatvienība bija klase. Izlase veidota atbilstoši IZM datiem par 8.-10. klašu un tajās esošo skolēnu skaitu 2010./2011. mācību gadā (Trapencieris u. c., 2012).

Aptauja tika veikta 2011. gada aprīḷa un maija mēnešos. Aptaujā piedalījās skolēni no 491 klases 327 vispārizglītojošajās skolās (Trapencieris u. c., 2012).

\subsection{Pētāmo mainīgo pazīmes un grupēšana}

Kā atkarīgās pazīmes promocijas darbā analizēti sekojoši pašnāvnieciskās uzvedības veidi: 
- domas par pašnāvību dzīves laikā (turpmāk - domas par pašnāvību), kuru noteikšanai respondentiem anketā bija jāatbild uz jautājumu, vai respondents ir pārdomājis/-usi konkrētu veidu, vietu vai rīcību pašnāvības izdarīšanai. Atbilžu varianti tika dihotomizēti, izveidojot divas grupas - “jāa” un “nē”. N̦emot vērā nepieciešamību diferencēt domas par pašnāvību ar salīdzinoši augstāku risku pašnāvības mēǵinājumam vai pabeigtai pašnāvībai, promocijas darba ietvaros izmantotā, respondentiem uzdotā jautājuma konstruēšanā izmantota pieeja domu par pašnāvību definēšanā, kurā tiek izdalītas aktīvas aktīvas domas par pašnāvību, definējot tās kā "domas par rīcību savas dzīves izbeigšanai, ietverot metodes identificēšanu, plāna esamību vai nodomu atbilstoši rīkoties" (Turecki and Brent, 2016);

- pašnāvības mēgeinājums dzīves laikā (turpmāk - pašnāvības mēǵinājums), kura noteikšanai respondentiem anketā bija jāatzīmē vai un cik reižu dzīves laikā respondents ir mēǵinājis/-usi izdarīt pašnāvību. Atbilžu varianti tika dihotomizēti, izveidojot divas grupas - “jā”” un “nē". Šãds jautājums un pieeja pusaudžu pašu ziņotā pašnāvības mēǵinājuma noteikšanai izmantoti arī vairākos citos pētījumos, kuros izmantoti ESPAD dati (Kokkevi et al., 2012; Kokkevi et al., 2011; Hibell et al., 2009).

Kā neatkarīgās pazīmes promocijas darbā analizētas šādas faktoru grupas - ar ğimenes vidi saistītie faktori:

- nedzīvošana ar abiem bioloğiskajiem vecākiem, kuras noteikšanai, atbilstoši ESPAD starptautiski izmantotajam jautājumam, respondentiem bija jāatzīmē cilvēki, kuri dzīvo ar respondentu vienā gimenē. Atbilžu varianti tika dihotomizēti, izveidojot divas grupas - "jā̄", kas noteikta, ja respondents atzīmējis, ka nedzīvo ar abiem biologiiskajiem vecākiem - tēvu un māti un “nē”, kas noteikta, ja respondents nav atzīmējis, ka dzīvo gan ar tēvu, gan māti. Līdzīga pieeja izmantota arī citos pētījumos (Kokkevi et al., 2012; Zaborskis, Sirvyte and Zemaitiene, 2016; Kokkevi et al., 2011); 
- vecāku emocionālais atbalsts, kura noteikšanai, atbilstoši ESPAD starptautiski izmantotajam jautājumam, respondentiem bija jānorāda cik bieži ir spēkā apgalvojums "Man ir viegli saņemt emocionālo atbalstu no mātes un/vai tēva". Atbilžu varianti tika apvienoti trīs kategorijās - "vienmēr/bieži", "dažreiz" un "reti/nekad";

- pašnāvnieciska pieredze ğimenē, kuras noteikšanai respondentiem bija jāatbild uz diviem atsevišķiem jautājumiem: "Vai kāds no Taviem ğimenes locekḷiem ir mēǵinājis izdarīt pašnāvību?" un "Vai kāds no Taviem ğimenes locekḷiem ir izdarījis pašnāvību?’. Atbilžu varianti tika dihotomizēti, izveidojot divas grupas - "jā", ja respondents uz kādu vai abiem atsevišķajiem jautājumiem devis apstiprinošu atbildi, un "nē", ja respondents uz abiem jautājumiem atbildējis noliedzoši;

- fiziska vardarbība gimenē, kura noteikta pēc respondentu atbildēm uz apgalvojumu "Tiku iesaistīts fiziskā vardarbībā savās mājās, kurā piedalījās arī kāds pieaugušais". Atbilžu varianti tika dihotomizēti, izveidojot divas grupas - “jā", un “nē";

- seksuāla uzmākšanās ǵimenē, kura noteikta pēc respondentu atbildēm uz apgalvojumu "Piedzīvoju seksuālu uzmākšanos, kurā bija iesaistīts kāds pieaugušais ǵimenes loceklis”. Atbilžu varianti tika dihotomizēti, izveidojot divas grupas - “jā" un "nē"; ar vienaudžu vidi saistîtie faktori:

- vienaudžu emocionālais atbalsts, kura noteikšanai, atbilstoši ESPAD starptautiski izmantotajam jautājumam, respondentiem bija jānorāda cik bieži ir spēkā apgalvojums "Man ir viegli saṇemt emocionālo atbalstu no mana labākā drauga/draudzenes". Atbilžu varianti tika apvienoti trīs kategorijās "vienmēr/bieži”, "dažreiz" un "reti/nekad";

- pašnāvnieciska pieredze vienaudžu vidū, kuras noteikšanai respondentiem bija jāatbild uz diviem atsevišķiem jautājumiem: "Vai kāds no Taviem draugiem vai pazin̄ām ir mēǵinājis izdarīt pašnāvību?" un "Vai kāds no 
Taviem draugiem vai paziṇām ir izdarījis pašnāvību?”. Atbilžu varianti tika dihotomizēti, izveidojot divas grupas - “jā", kas noteikta, ja respondents uz kādu vai abiem atsevišķajiem jautājumiem devis apstiprinošu atbildi, un "nē", ja respondents uz abiem jautājumiem atbildējis noliedzoši;

- vienaudžu ņirgāšanās skolā, kuras noteikšanai respondentiem bija jāatbild uz apgalvojumu "Klasesbiedri mani ir apsaukājuši”. Atbilžu varianti tika apvienoti, izveidojot trīs kategorijas - "vienmēr/bieži”, "dažreiz" un "nekad"; individuālie faktori:

- depresijas simptomu līmenis, kura noteikšanai izmantota Epidemiologiijas pētījumu centra Depresijas skalas (angl. - Center of Epidemiological Studies Depression-Scale) (CES-D) (Radloff, 1977) īsā (sešu jautājumu) forma, kas starptautiski izmantota ESPAD psihosociālā moduḷa ietvaros (Hibell et al., 2009). CES-D skalas pamatmērḳis nav klīniski nozīmīgas depresijas diagnostika, bet gan depresijas simptomu līmeņa noteikšana, lai mērītu atšķirības dažādās populācijas grupās (Radolff, 1977). CES-D ir viena no skalām, kas tiek rekomendēta dažāda depresijas simptomu līmeņa noteikšanai arī pusaudžu populācijā, bet ne klīniskas depresijas diferencēšanai, jo klīniskas depresijas robežpunktu noteikšana var rezultēties kḷūdaini pozitīvā atradē (Stockings et al., 2015). Skalas īsās formas validitāte tika novērtēta salīdzinot rezultātus ar pilnās CES-D skalas rezultātiem 5249 skolēnu aptaujā un atzīta par apmierinošu (Hibell et al., 2009). Respondentiem bija jāsniedz atbildes uz sešiem jautājumiem, proti, "Cik bieži pēdējo 7 dienu laikā..." a. "Tev bija zudusi apetīte, negribējās ēst”, b. “Tev bija grūtības koncentrēties tam, ko gribēji darīt", c. "juties nomākts/nomākta", d. "juti, ka ir jāpiepūlas un jāpiespiež sevi izdarīt to, kas jādara”, e. "juties skumji”, f. "nespēji darīt savu darbu (mājās, darbā, skolā)". Atbilžu varianti uz katru jautājumu bija - "reti vai nekad", "dažreiz", "bieži” un "gandrīz vienmēr". Rezultātu interpretācijā tika papildināta pieeja, kas izmantota ESPAD pētījumā 
(Hibell et al., 2009): atkarībā no atbildes uz katru no jautājumiem respondentam bija iespējams iegūt 1-4 punktus. Vadoties pēc vidējās iegūtās punktu summas sadalījuma kvartilēs, tika izdalītas trīs depresijas simptomu līmeṇa kategorijas - "zems" gadījumā, ja vidējā punktu summa bija divās zemākajās kvartilēs vidējo rādītāju sadalījumā, savukārt divas augstākās kvartiles tika proporcionāli sadalītas kategorijās "vidēji augsts" un "augsts";

- pašcieṇas līmenis, kura noteikšanai izmantota Rozenberga pašcieņas skala (angl. - Rosenberg's Self-esteem Scale), kas ir instruments, kas detalizēti izstrādāts balstoties uz pašcieņas konceptu un vispārējo pašcieņu mēra, novērtējot personas uzskatus par savu personīgo vērtību un sevis pieņemšanu (Rosenberg, 1965). Respondentiem bija jāatbild, cik lielā mērā viṇi piekrīit 10 apgalvojumiem: a. "kopumā esmu ar sevi apmierināts/a", b. "reizēm domāju, ka nekam nederu", c. "uzskatu, ka man ir daudzas labas īpašības", d. "spēju visu darìt tikpat labi kā vairums cilvēku", e. "domāju, ka man nav daudz ar ko lepoties", f. "reizēm es patiešām jūtos nevērtīgs/a", g. "domāju, ka esmu vērtīgs cilvēks, vismaz līdzvērtīgs citiem", h. "vēlos, kaut man būtu vairāk pašcieņas", i. "vispār sliecos uzskatīt sevi par neveiksminieku", j. "es pret sevi izturos pozitīvi", no kuriem pieci apgalvojumi (a, c, d, g, j) ir pozitīvi un pieci apgalvojumi (b, e, f, h, i) ir negatīvi. Uz katru no apgalvojumiem respondentiem bija jāatzīmē kāds no atbilžu variantiem - "pilnīgi piekrītu”, "piekrītu”, "nepiekrītu” un "pavisam nepiekrītu”. Atkarībā no sniegtās atbildes uz katru no apgalvojumiem respondentam bija iespējams iegūt 1-4 punktus augošā secībā, no 1 punkta, ja atzīmēta atbilde "piln̄̄gi piekrītu", līdz 4 punktiem, ja atzīmēta atbilde "nepavisam nepiekrītu" negatīvajos apgalvojumos un dilstošā secībā no 4 punktiem, ja atzīmēta atbilde "piln̄̄gi piekrītu", līdz 1 punktam, ja atzīmēta atbilde "nepavisam nepiekrītu" pozitīvajos apgalvojumos. Rezultātu interpretācijā tika papildināta pieeja, kas starptautiski izmantota ESPAD pētījumā (Hibell et al., 2009): pēc atbildēm uz visiem desmit 
jautājumiem tika aprēķināta katra respondenta iegūtā vidējā punktu summa. Vadoties pēc vidējās iegūtās punktu summas sadalījuma kvartilēs, tika izdalītas trīs pašcieņas līmeņa kategorijas - "augsts” gadījumā, ja vidējā punktu summa bija divās augstākajās kvartilēs vidējo rādītāju sadalījumā, savukārt divas zemākās kvartiles tika proporcionāli sadalītas kategorijās "vidēji zems" un "zems";

- veselības pašvērtējums, kura noteikšanai respondentiem bija jāatbild uz ESPAD starptautiski izmantoto jautājumu: "Cik apmierināts/-a Tu parasti esi ar savu veselības stāvokli?". Atbilžu varianti tika apvienoti, izveidojot trīs kategorijas - "neapmierināts", "vidēji apmierināts" un "apmierināts";

- riskanta alkohola lietošana, kura noteikta pēc respondentu atbildēm uz starptautiski izmantoto jautājumu: "Cik reizes savas dzìves laikā Tu esi apreibis/-usi no alkoholiskiem dzērieniem tā, ka ejot streipuḷoji, nevarēji skaidri parunāt, vēmi vai nevarēji atcerēties, kas notika?". Atbilžu varianti tika apvienoti, izveidojot trīs kategorijas - "nē", "1-2 reizes" un "3 un vairāk reizes". ESPAD un citos pētījumos šāda veida alkohola lietošana (piedzeršanās) tiek uzskatīta par vienu no dzeršanas paradumiem, kas raksturo riskantu alkohola lietošanu (Trapencieris u. c., 2012) un šāda veida atbilžu variantu apvienošana izmantota ESPAD starptautisko datu analīzē, nosakot piedzeršanās reižu skaita saistību ar pētītajiem psihosociālajiem mainīgajiem (Hibell et al., 2009);

- ikdienas smēḳēšana, kuras noteikšanai, atbilstoši ESPAD starptautiski izmantotajam jautājumam, respondentiem bija jāatzīmē cik bieži respondents ir smēķējis cigaretes pēdējo 30 dienu laikā. Atbilžu varianti tika dihotomizēti, izveidojot divas grupas - “jā̄”, ja respondents izsmēḳējis vismaz vienu cigareti dienā" un "nē", ja respondents izsmēḳējis mazāk par 1 cigareti dienā vai nav smēḳējis. Šāda pieeja ikdienas smēḳētāju noteikšanā izmantota arī citā pētījumā (Kokkevi et al., 2012); 
- narkotiku lietošana, kuras noteikšanai, atbilstoši starptautiski ESPAD izmantotajiem jautājumiem, respondentiem bija jāatzīmē cik bieži dzīves laikā respondents ir lietojis katru no sekojošām vielām (atsevišķss jautājums par katru no vielām) - marihuāna/hašišs, amfetamīns, LSD/citi halucinogēni, kreks, kokaīns, heroīns, ekstazī vai spice. Atbilžu varianti tika dihotomizēti, izveidojot divas grupas - “jā”, ja respondents atzīmējis kādu no atbilžu variantiem, kas raksturo faktu, ka respondents kādu vai vairākas no vielām dzīves laikā ir lietojis, un "nē”, ja respondents atzīmējis, ka nevienu no iepriekš minētajām vielām nav lietojis. Šāda pieeja izmantota arī citā pētījumā (Kokkevi et al., 2012). Kā neatkarīgās pazīmes pētīti arī sociāldemogrāfiskie raksturlielumi:

- dzimums - zēns vai meitene;

- vecums, kas aprēḳināts pēc respondenta sniegtās informāciju par viṇa dzimšanas gadu un mēnesi, aprēķinos ņemot vērā aptaujas veikšanas gadu un mēnesi. Tādējādi tika aprēķināts skolēna vecums mēnesī, kurā tika veikta anketēšana, un izveidotas divas respondentu vecuma grupas 14-15 gadi un 1617 gadi. Atbilstoši starptautiskajām rekomendācijām par pusaudzi tiek uzskatīta 10-19 gadus veca persona (WHO, 2017), kas ietver promocijas darba ietvaros pētìtās vecuma grupas;

- ǵimenes materiālais stāvoklis, kura noteikšanai, atbilstoši ESPAD starptautiski izmantotajam jautājumam, respondentam bija jāatzīmē kāds ir viṇa ǵimenes materiālais stāvoklis salīdzinājumā ar citām ǵimenēm valstī. Atbilžu varianti tika apvienoti, izveidojot trīs kategorijas - "sliktāks", "vidējs" un "labāks". Pētîjumos noskaidrots, ka subjektīvais sociālekonomiskā statusa mērījums reprezentē arī sociālekonomisko situāciju saistīto personīgo pieredzi (Singh-Manoux, Adler and Marmot, 2003) un pusaudžu vecumā tam var būt būtiskāka sakarība ar psihoemocionālo labklājību nekā objektīvajiem sociālekonomiskā statusa mērījumiem (Sweeting and Hunt, 2014). 


\subsection{Pētāmās populācijas raksturojums}

Kopumā datu analīzē iekḷauti 7299 respondenti vecumā 14 līdz 17 gadiem - $3471(47,6 \%)$ zēni un $3828(52,4 \%)$ meitenes. Vidējais respondentu vecums bija 15,5 gadi (standartnovirze 0,95). Skolēnu sadalījums vecuma grupās bija sekojošs: 14-15 gadi - 3670 (50,3\%); 16-17 gadi - 3629 (49,7\%). Skolēnu sadalījums pēc dzīvesvietas bija sekojošs: Rīga - 1767 (24,2\%); lielās pilsētas - 1766 (24,2\%); citas pilsētas - 2404 (32,9\%); lauki - 1362 (18,7\%).

\subsection{Statistiskā analīze}

Atbilstoši promocijas darba mērķim un uzdevumiem veikta dzimumstratificētā analīze.

Datu analīzei izmantotas aprakstošās statistikas metodes: biežumu sadalījums, vidējo vērtību aprēķināšana un Hī kvadrāta (angl. - chi-square) tests izmantots respondentu apakšgrupu salīdzināšanai $2 \times 2$ škēerstabulās, savukārt, lai salīdzinātu neatkarīgās grupas, kuru skaits pārsniedz divas, izmantota procentuālo atšķirību statistiskās nozīmības intervāla noteikšana, izmantojot Vilsona metodi (angl. - Wilson score interval method) (Newcombe, 1998).

Spīrmena korelācijas (angl. - Spearman correlation) koeficients izmantots, lai noteiktu korelācijas starp pētītajiem pašnāvnieciskās uzvedības veidiem, kā arī kā pirmais solis kolinearitātes (angl. - collinearity) pārbaudē starp neatkarīgajiem main̄̄gajiem daudzfaktoru logiistiskās regresijas modeḷos.

Lai noteiktu asociāciju starp atkarīgo un neatkarīgo pazīmi, izmantots izredžu attiecību aprēḳins (angl. - odds ratio).

Daudzfaktoru logistiskās regresijas modeḷos analizēta dažādu faktoru saistība ar pusaudžu pašnāvniecisko uzvedību dzimumu grupās. Katram pašnāvnieciskās uzvedības veidam veikta atsevišķa daudzfaktoru regresijas 
analīze, atsevišķi analizējot sakarības starp katru pašnāvnieciskās uzvedības veidu un faktoriem trīs atsevišķās faktoru grupās - ar gimenes vidi saistītie faktori, ar vienaudžu vidi saistîtie faktori un individuālie faktori.

Lai izvēlētos daudzfaktoru regresijas modeḷos iekḷaujamos mainīgos izmantota mērḳtiecīgās atlases (angl. - purposeful selection) metode, kas paredz sākotnēji noteikt katra neatkarīgā main̄̄gā saistību ar iznākumu, izmantojot vienfaktora regresijas analīzi un regresijas modeḷos iekḷaut tos main̄̄gos, kuru p vērtība ir mazāka par 0,25, kā arī main̄̄gos, kuru ietekme vienfaktora regresijas analīzē nav statistiski nozīmīga, bet kuri var būt potenciāli noz̄īmīgi izveidotā modeḷa kontekstā (Zhang, 2016). Atbilstoši vienfaktoru regresijas analīzes rezultātiem regresijas modeḷos iekḷauti visi pētītie ar ǵimenes vidi saistītie, vienaudžu vidi raksturojošie, individuālie faktori un sociāldemogrāfiskie raksturlielumi (vienfaktoru analīzes rezultāti detalizēti aprakstīti promocijas darba pilnajā versijā, bet darba kopsavilkumā analizēti tikai samērotie rādītāji).

Visos regresijas modeḷos iekḷautajiem neatkarīgajiem main̄̄gajiem tika veikta kolinearitātes (angl. - collinearity) pārbaude, lai noteiktu, vai starp neatkarīgajām pazīmēm nepastāv cieša savstarpējā saistība. Ciešas saistības gadījumā starp neatkarīgajiem main̄̄gajiem nevar izdarīt secinājumus, kurš no neatkarīgajiem main̄̄gajiem ietekmē atkarīgo main̄̄go. Kolinearitātes pārbaudei izmantots Spīrmena korelācijas (angl. - Spearman correlation) koeficients, Tolerances tests un dispersijas inflācijas faktors (angl. - variance inflation factor) (VIF). Tolerances testa vērtība, kas ir mazāka par 0,1, un VIF vērtība, kas ir lielāka par 10, norāda uz regresijas neatkarīgo mainīgo kolinearitāti (Field, 2013). Kolinearitātes pārbaude starp neatkarīgajiem mainīgajiem dzimumu grupās liecina, ka kolinearitāte netraucē izdarīt secinājumus par regresijas modeḷos iekḷauto neatkarīgo main̄̄go ietekmi uz atkarīgajiem main̄̄gajiem - domām par pašnāvību un pašnāvības mēǵinājumiem. 
Visiem statistiskajiem testiem noteikts būtiskuma līmenis (p) 0,05 un rezultāti atzīti par statistiski nozīmīgiem, ja p vērtība bija mazāka par iepriekš minēto būtiskuma līmeni.

Datu analīzei izmantotas datorprogrammas MS Excel un IBM SPSS. 


\section{REZULTĀTI}

\subsection{Pašnāvnieciskā uzvedība sociāldemogrāfiskajās grupās}

Kopumā domas par pašnāvību atzīmējuši 15,7\% ( $\mathrm{n}=1142 ; 95 \% \mathrm{TI}=$ 14,9-16,6) respondentu $-11,7 \%(\mathrm{n}=404 ; 95 \% \mathrm{TI}=10,7-12,9)$ zēnu un $19,4 \%$ $(\mathrm{n}=738 ; 95 \% \mathrm{TI}=18,1-20,7)$ meiteņu, bet pašnāvības mēginājumu 8,2\% $(\mathrm{n}=$ $594 ; 95 \% \mathrm{TI}=7,6-8,8)$ respondentu $-5,9 \%(\mathrm{n}=205 ; 95 \% \mathrm{TI}=5,2-6,8)$ zēnu un $10,2 \%(\mathrm{n}=389 ; 95 \% \mathrm{TI}=9,3-11,2)$ meiteņu. Atšķirības dzimumu grupās ir statistiski nozīmīgas gan domu par pašnāvību $\left(\mathrm{p}<0,001\right.$, df $\left.=1, \chi^{2}=79,31\right)$, gan pašnāvības mēginājumu ( $\left.\mathrm{p}<0,05, \mathrm{df}=1, \chi^{2}=43,65\right)$ izplatībā.

Statistiski nozīmīgas atšķirības vērojamas arī domu par pašnāvību izplatībā pusaudžu vecuma grupās gan zēniem $\left(\mathrm{p}<0,05, \mathrm{df}=1, \chi^{2}=4,25\right)$, gan meitenēm $\left(\mathrm{p}<0,05, \mathrm{df}=1, \chi^{2}=5,25\right)$, taču pašnāvības mēǵinājumu izplatībā statistiski nozīmīgas atšķirības pusaudžu vecuma grupās netika konstatētas ne zēniem $\left(\mathrm{p}>0,05, \mathrm{df}=1, \chi^{2}=0,77\right)$ ne meitenēm $\left(\mathrm{p}>0,05, \mathrm{df}=1, \chi^{2}=0,15\right)$ (sk. 3.1. att.).

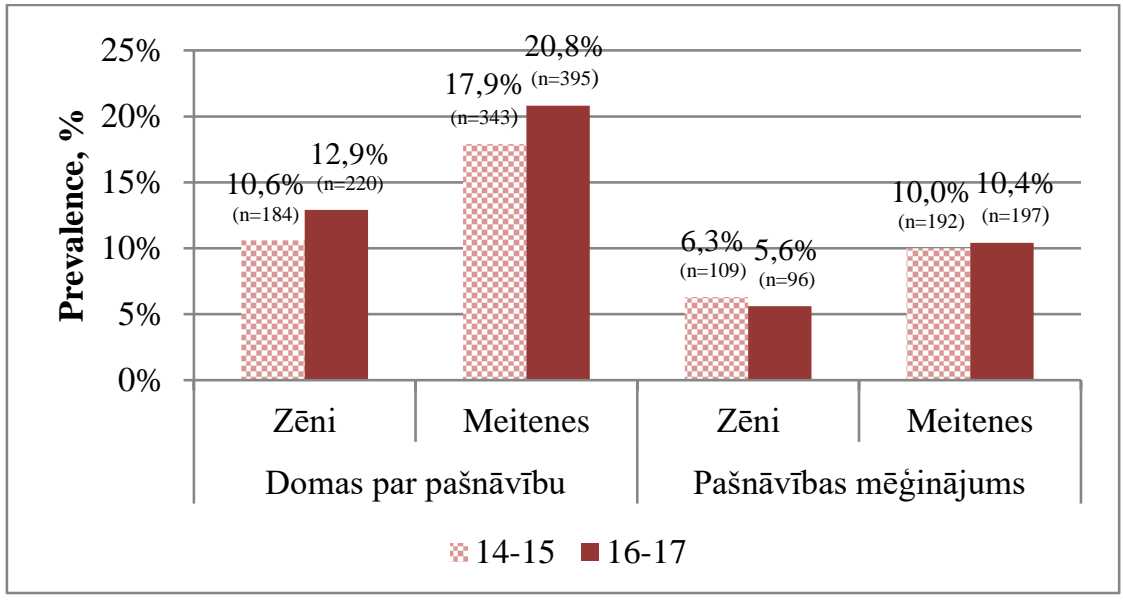

3.1. att. Pašnāvnieciskās uzvedības prevalence dzimuma un vecuma grupās, \% 
Procentuālo atšķirību statistiskās nozīmības intervālu analīze liecina, ka domas par pašnāvību ir statistiski nozīmīgi izplatītākas starp abu dzimumu pusaudžiem, kuri savas ǵimenes materiālo stāvokli salīdzinājumā ar citām ǵimenēm Latvijā vērtē kā sliktāku, savukārt pašnāvība mēǵinājumi iepriekš minētajā ǵimenes materiālā stāvokḷa vērtējuma kategorijā ir statistiski nozīmīgi izplatītāki tikai meitenēm (sk. 3.1. tab.).

3.1. tabula

\section{Pašnāvnieciskās uzvedības prevalence ǵimenes materiālā stāvokḷa kategorijās dzimumu grupās}

\begin{tabular}{|c|c|c|c|c|}
\hline \multirow{2}{*}{\multicolumn{2}{|c|}{ Domas par pašnāvību }} & \multicolumn{3}{|c|}{ G̣imenes materiālais stāvoklis } \\
\hline & & Sliktāks & Vidējs & Labāks \\
\hline \multirow[b]{2}{*}{ Zēni } & $\mathrm{n}$ & 52 & 132 & 218 \\
\hline & $\begin{array}{c}\% \\
(95 \% \mathrm{TI}) \\
\end{array}$ & $\begin{array}{c}19,8^{*} \\
(15,4-25,0)\end{array}$ & $\begin{array}{c}11,4 \\
(9,7-13,3)\end{array}$ & $\begin{array}{c}11,0 \\
(9,7-12,5)\end{array}$ \\
\hline \multirow[b]{2}{*}{ Meitenes } & $\mathrm{n}$ & 112 & 301 & 315 \\
\hline & $\begin{array}{c}\% \\
(95 \% \mathrm{TI}) \\
\end{array}$ & $\begin{array}{c}30,9^{*} \\
(26,4-35,9) \\
\end{array}$ & $\begin{array}{c}19,7 \\
(17,7-21,7) \\
\end{array}$ & $\begin{array}{c}16,7 \\
(15,1-18,5) \\
\end{array}$ \\
\hline \multirow{2}{*}{\multicolumn{2}{|c|}{ Pašnāvības mēǵinājums }} & \multicolumn{3}{|c|}{ G̣imenes materiālais stāvoklis } \\
\hline & & Sliktāks & Vidējs & Labāks \\
\hline \multirow[b]{2}{*}{ Zēni } & $\mathrm{n}$ & 20 & 63 & 121 \\
\hline & $\begin{array}{c}\% \\
(95 \% \mathrm{TI}) \\
\end{array}$ & $\begin{array}{c}7,5 \\
(4,9-11,3) \\
\end{array}$ & $\begin{array}{c}5,4 \\
(4,2-6,9) \\
\end{array}$ & $\begin{array}{c}6,1 \\
(5,1-7,2) \\
\end{array}$ \\
\hline \multirow[b]{2}{*}{ Meitenes } & $\mathrm{n}$ & 57 & 151 & 176 \\
\hline & $\begin{array}{c}\% \\
(95 \% \mathrm{TI})\end{array}$ & $\begin{array}{c}15,6^{*} \\
(12,2-19,7)\end{array}$ & $\begin{array}{c}9,8 \\
(8,4-11,4)\end{array}$ & $\begin{array}{c}9,3 \\
(8,1-10,7)\end{array}$ \\
\hline
\end{tabular}

* statistiski nozīmīgas atšḳirīibas

\subsection{Pašnāvnieciskās uzvedības savstarpējā saistība}

No respondentiem, kuri atzīmējuši pašnāvības mēginājumu dzīves laikā, 66,5\% (n = 391; 95\% TI = 62,6-70,2) atzīmējuši arī domas par pašnāvību, savukārt no respondentiem, kuri atzīmējuši domas par pašnāvību, 34,4\% (n = 391; 95\% TI $=31,7-37,2$ ) atzīmējuši arī pašnāvības mēgeinājumu. Korelācija 
starp pētītajiem pašnāvnieciskās uzvedības veidiem ir statistiski nozīmīga un Spīrmena korelācijas (angl. - Spearman correlation) koeficients 0,41 liecina, ka starp pētītajiem pašnāvnieciskās uzvedības veidiem pastāv vāja korelācija (Hinkle, Wiersma and Jurs, 2003).

\subsection{Pašnāvnieciskā uzvedība un ar ğimenes vidi saistītie faktori}

Pusaudžu pašnāvnieciskās uzvedības saistība ar gimenes vidi raksturojošajiem faktoriem analizēta daudzfaktoru regresijas modeḷos. Modelī 1 veikta katra pētītā faktora samērošana ar respondenta vecumu un gimenes materiālo stāvokli. Modelī 2 veikta faktoru samērošana ar respondenta vecumu, ǵimenes materiālo stāvokli un savstarpēji ar citiem pētītajiem ar gimenes vidi saistītajiem faktoriem. Abi daudzfaktoru regresijas modeḷi tika izveidoti katrai dzimumu grupai, katram pašnāvnieciskās uzvedības veidam atsevišḳi, kopā veidojot 8 modeḷus (sk. 3.2.-3.5. tab.).

Analizējot pusaudžu domu par pašnāvību saistību ar nedzīvošanu ar abiem biologiskajiem vecākiem, vērojams, ka pēc samērošanas modelī 1 nedzīvošana ar abiem biologiskajiem vecākiem zēniem domu par pašnāvību izredzes palielina gandrīz divas reizes $(\mathrm{OR}=1,9)$, bet pēc samērošanas modelī 2 - 1,3 reizes, salīdzinot ar zēniem, kuri dzīvo ar abiem biologiskajiem vecākiem, savukārt meiteņu vidū pēc samērošanas modelī 1 nedzīvošana ar abiem biologiskajiem vecākiem domu par pašnāvību izredzes palielina 1,4 reizes, bet pēc samērošanas modelī 2 saistība vairs nav statistiski nozīmīga (sk. 3.2.-3.3. tab.).

Analizējot nedzīvošanas ar abiem biologiskajiem vecākiem saistību ar pašnāvības mēǵinājumu, vērojams, ka pēc samērošanas modelī 1 zēniem nedzīvošana ar abiem biologiiskajiem vacākiem pašnāvības mēǵinājuma izredzes palielina 3,2 reizes, bet pēc samērošanas modelī 2 - 2,1 reizi, salīdzinot ar zēniem, kuri dzīvo ar abiem bioloǵiskajiem vecākiem. Savukārt 
meiteņu vidū pēc samērošanas modelī 1 nedzīvošana ar abiem biologiskajiem vecākiem pašnāvības mēginājuma izredzes palielina gandrīz divas reizes $(\mathrm{OR}=$ 1,8), bet pēc samērošanas modelī $2-1,4$ reizes, salīdzinot ar meitenēm, kuras dzīvo ar abiem biolog̣iskajiem vecākiem (sk. 3.4.-3.5. tab.).

Analizējot saistības ar vecāku emocionālo atbalstu vērojams, ka reti/nekad saṇemts vecāku emocionālais atbalsts pēc samērošanas modelī 1 zēniem domu par pašnāvību izredzes palielina 3,1 reizi, dažreiz saṇemts vecāku emocionālais atbalsts $-1,7$ reizes, bet pēc samērošanas modelī 2 izredzes domām par pašnāvību ir attiecīgi 2,3 un 1,4 reizes augstākas, salīdzinot ar zēniem, kuri vecāku emocionālo atbalstu saņem vienmēr/bieži. Savukārt meiteņu vidū reti/nekad saṇemts vecāku emocionālais atbalsts pēc samērošanas modelī 1 domu par pašnāvību izredzes palielina 3,4 reizes, dažreiz saņemts vecāku emocionālais atbalsts - 2,4 reizes, bet pēc samērošanas modelī 2 izredzes domām par pašnāvību ir attiecīgi 2,5 un divas reizes augstākas, salīdzinot ar meitenēm, kuras vecāku emocionālo atbalstu saņem vienmēr/bieži (sk. 3.2.-3.3. tab.).

Attiecībā uz pašnāvības mēgeinājumiem reti/nekad saņemts vecāku emocionālais atbalsts pēc samērošanas modelī 1 zēniem pašnāvības mēǵinājuma izredzes palielina 3,7 reizes, bet pēc samērošanas modelī 2 2,4 reizes, salīdzinot ar zēniem, kuri vecāku emocionālo atbalstu saṇem vienmēr/bieži. Zēniem saistība starp pašnāvības mēginājumu un dažreiz saņemtu vecāku emocionālo atbalstu gan vienfaktora analīzē, gan pēc samērošanas modelī 1 un modelī 2 nav statistiski nozīmīga. Savukārt meitemēm reti/nekad saņemts vecāku emocionālais atbalsts pēc samērošanas modelī 1 pašnāvības mēǵinājuma izredzes palielina 3,3 reizes, dažreiz saṇemts vecāku emocionālais atbalsts - 2,4 reizes, bet pēc samērošanas modelī 2 izredzes pašnāvības mēǵinājumam ir attiecīgi 2,2 un gandrīz divas reizes $(\mathrm{OR}=$ 
1,9) augstākas, salīdzinot ar meitenēm, kuras vecāku emocionālo atbalstu saṇem vienmēr/bieži (sk. 3.4.-3.5. tab.).

Pašnāvnieciska pieredze gimenē pēc samērošanas modelī 1 zēniem domu par pašnāvību izredzes palielina 13,3 reizes, bet pēc samērošanas modelī 2 - 8,5 reizes, salīdzinot ar zēniem bez pašnāvnieciskas pieredzes gimenē. Meiteņu vidū pēc samērošanas modelī 1 pašnāvnieciska pieredze ǵimenē domu par pašnāvību izredzes palielina 3,5 reizes, bet pēc samērošanas modelī 2 2,5 reizes, salīdzinot ar meitenēm bez pašnāvnieciskas pieredzes gimenē (sk. 3.2.-3.3. tab.).

Attiecībā uz pašnāvības mēgeinājumiem pašnāvnieciska pieredze gímenē pēc samērošanas modelī 1 zēniem pašnāvības mēǵinājuma izredzes palielina 9,3 reizes, bet pēc samērošanas modelī 2 - 3,5 reizes, salīdzinot ar zēniem bez pašnāvnieciskas pieredzes gímenē. Meitenēm pēc samērošanas modelī 1 pašnāvnieciska pieredze ǵimenē pašnāvības mēǵinājuma izredzes palielina 4,2 reizes, bet pēc samērošanas modelī 2 - trīs reizes, salīdzinot ar meitenēm bez pašnāvnieciskas pieredzes ğimenē (sk. 3.4.-3.5. tab.).

Fiziska vardarbība ğimenē pēc samērošanas modelī 1 zēniem domu par pašnāvību izredzes palielina 5,4 reizes, bet pēc samērošanas modelī 2 2,5 reizes, salīdzinot ar zēniem bez fiziskās vardarbības pieredzes ǵimenē. Meiteņu vidū pēc samērošanas modelī 1 fiziska vardarbība ğimenē domu par pašnāvību izredzes palielina 3,7 reizes, bet pēc samērošanas modelī 2 2,4 reizes, salīdzinot ar meitenēm bez šādas pieredzes (sk. 3.2.-3.3. tab.).

Saistībā ar pašnāvības mēǵinājumiem fiziska vardarbība ǵimenē pēc samērošanas modelī 1 zēniem pašnāvības mēǵinājuma izredzes palielina 8,2 reizes, bet pēc samērošanas modelī 2 - trīs reizes, salīdzinot ar zēniem bez šādas pieredzes. Meiteņu vidū pēc samērošanas modelī 1 fiziska vardarbība ǵimenē pašnāvības mēginājuma izredzes palielina 3,2 reizes, bet pēc 
samērošanas modelī 2 - gandrīz divas reizes $(\mathrm{OR}=1,9)$, salīdzinot ar meitenēm bez šādas pieredzes (sk. 3.4.-3.5. tab.).

Seksuāla uzmākšanās gímenē pēc samērošanas modelī 1 zēniem domu par pašnāvību izredzes palielina 10,4 reizes, salīdzinot ar zēniem, kuri seksuālu uzmākšanos nav piedzīvojuši, bet pēc samērošanas modelī 2 saistība vairs nav statistiski nozīmīga. Meiteņu vidū pēc samērošanas modelī 1 seksuāla uzmākšanās ǵimenē domu par pašnāvību izredzes palielina 3,2 reizes, bet pēc samērošanas modelī 2 saistība vairs nav statistiski nozīmīga (sk. 3.2.-3.3. tab.).

Saistībā ar pašnāvības mēǵinājumiem seksuāla uzmākšanās ǵimenē pēc samērošanas modelī 1 zēniem pašnāvības mēǵinājuma izredzes palielina 16,1 reizi, salīdzinot ar zēniem, kuri seksuālu uzmākšanos nav piedzīvojuši, bet pēc samērošanas modelī $2-3,1$ reizi. Meitenu vidū pēc samērošanas modelī 1 seksuāla uzmākšanās ǵimenē pašnāvības mēǵinājuma izredzes palielina 3,5 reizes, bet pēc samērošanas modelī 2 saistība vairs nav statistiski nozīmīga (sk. 3.4.-3.5. tab.). 
Daudzfaktoru loǵistiskās regresijas modeli pusaudžu domu par pašnāvību saistībai ar ǵimenes vidi raksturojošiem faktoriem zēniem

\begin{tabular}{|c|c|c|c|c|}
\hline \multirow{2}{*}{ Faktors } & \multicolumn{2}{|c|}{ Modelis $1 *$} & \multicolumn{2}{|c|}{ Modelis $2 * *$} \\
\hline & OR $(95 \% \mathrm{TI})$ & $\mathrm{p}$ & OR $(95 \% \mathrm{TI})$ & $\mathrm{p}$ \\
\hline \multicolumn{5}{|c|}{ Nedz̄̄vo ar abiem biologiskajiem vecākiem } \\
\hline Jā & $1,9(1,6-2,4)$ & $\mathrm{p}<0,001$ & $1,3(1,0-1,6)$ & $\mathrm{p}<0,05$ \\
\hline $\mathrm{Ne \overline { }}$ & 1,0 & & 1,0 & \\
\hline \multicolumn{5}{|c|}{ Vecāku emocionālais atbalsts } \\
\hline Reti/nekad & $3,1(2,3-4,2)$ & $\mathrm{p}<0,001$ & $2,3(1,7-3,3)$ & $\mathrm{p}<0,001$ \\
\hline Dažreiz & $1,7(1,3-2,3)$ & $\mathrm{p}<0,001$ & $1,4(1,0-2,0)$ & $\mathrm{p}<0,05$ \\
\hline Vienmēr/bieži & 1,0 & & 1,0 & \\
\hline \multicolumn{5}{|c|}{ Pašnāvnieciska pieredze gimenē } \\
\hline $\mathrm{Jā}$ & $13,3(10,2-17,4)$ & $\mathrm{p}<0,001$ & $8,5(6,3-11,6)$ & $\mathrm{p}<0,001$ \\
\hline $\mathrm{Ne}$ & 1,0 & & 1,0 & \\
\hline \multicolumn{5}{|c|}{ Fiziska vardarbība gimenē } \\
\hline $\mathrm{Ja}$ & $5,4(4,2-6,9)$ & $\mathrm{p}<0,001$ & $2,5(1,8-3,4)$ & $\mathrm{p}<0,001$ \\
\hline $\mathrm{Ne \overline {e }}$ & 1,0 & & 1,0 & \\
\hline \multicolumn{5}{|c|}{ Seksuāla uzmākšanās gimenē } \\
\hline Jā & $10,4(7,0-15,5)$ & $\mathrm{p}<0,001$ & $1,6(0,9-2,7)$ & $\mathrm{p}>0,05$ \\
\hline $\mathrm{Ne}$ & & & 1,0 & \\
\hline
\end{tabular}

* veikta katra faktora samērošana ar respondenta vecumu un ǵimenes materiālo stāvokli

** veikta katra faktora samērošana ar respondenta vecumu, ǵimenes materiālo stāvokli un savstarpēji ar pētītajiem ğimenes vidi raksturojošajiem faktoriem 
Daudzfaktoru loǵistiskās regresijas modeli pusaudžu domu par pašnāvību saistībai ar ğimenes vidi raksturojošiem faktoriem meitenēm

\begin{tabular}{|c|c|c|c|c|}
\hline \multirow{2}{*}{ Faktors } & \multicolumn{2}{|c|}{ Modelis $1 *$} & \multicolumn{2}{|c|}{ Modelis $2 * *$} \\
\hline & OR $(95 \% \mathrm{TI})$ & $\mathrm{p}$ & OR $(95 \% \mathrm{TI})$ & $\mathrm{p}$ \\
\hline \multicolumn{5}{|c|}{ Nedz̄̄vo ar abiem biologiskajiem vecākiem } \\
\hline Jā & $1,4(1,2-1,6)$ & $\mathrm{p}<0,001$ & $1,1(1,0-1,4)$ & $p>0,05$ \\
\hline $\mathrm{Ne \overline {e }}$ & 1,0 & & 1,0 & \\
\hline \multicolumn{5}{|c|}{ Vecāku emocionālais atbalsts } \\
\hline Reti/nekad & $3,4(2,7-4,4)$ & $\mathrm{p}<0,001$ & $2,5(1,9-3,3)$ & $\mathrm{p}<0,001$ \\
\hline Dažreiz & $2,4(1,9-3,0)$ & $\mathrm{p}<0,001$ & $2,0(1,6-2,5)$ & $\mathrm{p}<0,001$ \\
\hline Vienmēr/bieži & 1,0 & & 1,0 & \\
\hline \multicolumn{5}{|c|}{ Pašnāvnieciska pieredze gimenē } \\
\hline Jā & $3,5(2,8-4,4)$ & $\mathrm{p}<0,001$ & $2,5(2,0-3,2)$ & $\mathrm{p}<0,001$ \\
\hline $\mathrm{Ne}$ & 1,0 & & 1,0 & \\
\hline \multicolumn{5}{|c|}{ Fiziska vardarbība ǵgimenē } \\
\hline $\mathrm{Ja}$ & $3,7(3,0-4,6)$ & $\mathrm{p}<0,001$ & $2,4(1,9-3,1)$ & $\mathrm{p}<0,001$ \\
\hline $\mathrm{Ne \overline {e }}$ & 1,0 & & 1,0 & \\
\hline \multicolumn{5}{|c|}{ Seksuāla uzmākšanās gimenē } \\
\hline Jā & $3,2(1,8-5,9)$ & $\mathrm{p}<0,001$ & $1,5(0,8-3,0)$ & $\mathrm{p}>0,05$ \\
\hline $\mathrm{Ne \overline { }}$ & 1,0 & & 1,0 & \\
\hline
\end{tabular}

* veikta katra faktora samērošana ar respondenta vecumu un ǵimenes materiālo stāvokli

** veikta katra faktora samērošana ar respondenta vecumu, ǵimenes materiālo stāvokli un savstarpēji ar pētītajiem ğimenes vidi raksturojošajiem faktoriem 
Daudzfaktoru logistiskās regresijas modeḷi pusaudžu pašnāvības mēéginājumu saistībai ar ğimenes vidi raksturojošiem faktoriem zēniem

\begin{tabular}{|c|c|c|c|c|}
\hline \multirow{2}{*}{ Faktors } & \multicolumn{2}{|c|}{ Modelis $1^{*}$} & \multicolumn{2}{|c|}{ Modelis $2 * *$} \\
\hline & OR (95\% TI) & $\mathrm{p}$ & OR $(95 \% \mathrm{TI})$ & $\mathrm{p}$ \\
\hline \multicolumn{5}{|c|}{ Nedż̄̄vo ar abiem biologiskajiem vecākiem } \\
\hline $\mathrm{Ja}$ & $3,2(2,4-4,4)$ & $\mathrm{p}<0,001$ & $2,1(1,5-3,0)$ & $\mathrm{p}<0,001$ \\
\hline $\mathrm{Ne \overline { }}$ & 1,0 & & 1,0 & \\
\hline \multicolumn{5}{|c|}{ Vecāku emocionālais atbalsts } \\
\hline Reti/nekad & $3,7(2,6-5,4)$ & $\mathrm{p}<0,001$ & $2,4(1,5-3,6)$ & $\mathrm{p}<0,001$ \\
\hline Dažreiz & $1,4(0,9-2,2)$ & $\mathrm{p}>0,05$ & $1,0(0,6-1,5)$ & $\mathrm{p}>0,05$ \\
\hline Vienmēr/bieži & 1,0 & & 1,0 & \\
\hline \multicolumn{5}{|c|}{ Pašnāvnieciska pieredze gimenēe } \\
\hline $\mathrm{Jā}$ & $9,3(6,8-12,9)$ & $\mathrm{p}<0,001$ & $3,5(2,3-5,2)$ & $\mathrm{p}<0,001$ \\
\hline $\mathrm{Ne \overline { }}$ & 1,0 & & 1,0 & \\
\hline \multicolumn{5}{|c|}{ Fiziska vardarbība gimenē } \\
\hline $\mathrm{Jā}$ & $8,2(6,0-11,2)$ & $\mathrm{p}<0,001$ & $3,0(2,0-4,5)$ & $\mathrm{p}<0,001$ \\
\hline $\mathrm{Ne}$ & 1,0 & & 1,0 & \\
\hline \multicolumn{5}{|c|}{ Seksuāla uzmākšanās gimenēe } \\
\hline $\mathrm{Jā}$ & $16,1(10,6-24,5)$ & $\mathrm{p}<0,001$ & $3,1(1,8-5,5)$ & $\mathrm{p}<0,001$ \\
\hline $\mathrm{Ne \overline {c }}$ & 1,0 & & 1,0 & \\
\hline
\end{tabular}

* veikta katra faktora samērošana ar respondenta vecumu un ǵimenes materiālo stāvokli ** veikta katra faktora samērošana ar respondenta vecumu, ǵimenes materiālo stāvokli un savstarpēji ar pētītajiem ǵimenes vidi raksturojošajiem faktoriem 
Daudzfaktoru logistiskās regresijas modeḷi pusaudžu pašnāvības mēḡinājumu saistībai ar ğimenes vidi raksturojošiem faktoriem meitenēm

\begin{tabular}{|c|c|c|c|c|}
\hline \multirow{2}{*}{ Faktors } & \multicolumn{2}{|c|}{ Modelis $1 *$} & \multicolumn{2}{|c|}{ Modelis $2 * *$} \\
\hline & OR $(95 \% \mathrm{TI})$ & $\mathrm{p}$ & OR $(95 \% \mathrm{TI})$ & $\mathrm{p}$ \\
\hline \multicolumn{5}{|c|}{ Nedzīvo ar abiem biologiskajiem vecākiem } \\
\hline $\mathrm{Ja}$ & $1,8(1,4-2,2)$ & $\mathrm{p}<0,001$ & $1,4(1,1-1,8)$ & $\mathrm{p}<0,05$ \\
\hline $\mathrm{Ne \overline { }}$ & 1,0 & & 1,0 & \\
\hline \multicolumn{5}{|c|}{ Vecāku emocionālais atbalsts } \\
\hline Reti/nekad & $3,3(2,4-4,4)$ & $\mathrm{p}<0,001$ & $2,2(1,6-3,0)$ & $\mathrm{p}<0,001$ \\
\hline Dažreiz & $2,4(1,8-3,1)$ & $\mathrm{p}<0,001$ & $1,9(1,4-2,5)$ & $\mathrm{p}<0,001$ \\
\hline Vienmēr/bieži & 1,0 & & 1,0 & \\
\hline \multicolumn{5}{|c|}{ Pašnāvnieciska pieredze gimenē } \\
\hline Jā & $4,2(3,3-5,4)$ & $\mathrm{p}<0,001$ & $3,0(2,3-3,9)$ & $\mathrm{p}<0,001$ \\
\hline $\mathrm{Ne \overline { }}$ & 1,0 & & 1,0 & \\
\hline \multicolumn{5}{|c|}{ Fiziska vardarbība gimenē } \\
\hline $\mathrm{Jā}$ & $3,2(2,5-4,2)$ & $\mathrm{p}<0,001$ & $1,9(1,4-2,6)$ & $\mathrm{p}<0,001$ \\
\hline $\mathrm{Ne}$ & 1,0 & & 1,0 & \\
\hline \multicolumn{5}{|c|}{ Seksuāla użmākšanās gimenē } \\
\hline $\mathrm{Ja}$ & $3,5(1,8-6,8)$ & $\mathrm{p}<0,001$ & $1,7(0,8-3,6)$ & $p>0,05$ \\
\hline $\mathrm{Ne}$ & 1,0 & & 1,0 & \\
\hline
\end{tabular}

* veikta katra faktora samērošana ar respondenta vecumu un gimenes materiālo stāvokli ** veikta katra faktora samērošana ar respondenta vecumu, ǵimenes materiālo stāvokli un savstarpēji ar pētītajiem ǵimenes vidi raksturojošajiem faktoriem

\subsection{Pašnāvnieciskā uzvedība un ar vienaudžu vidi saistītie faktori}

Pusaudžu pašnāvnieciskās uzvedības saistība ar vienaudžu vidi raksturojošajiem faktoriem analizēta daudzfaktoru regresijas modeḷos. Modelī 1 veikta katra pētītā faktora samērošana ar respondenta vecumu un ǵimenes materiālo stāvokli. Modelī 2 veikta faktoru samērošana ar respondenta vecumu, gimenes materiālo stāvokli un savstarpēji ar citiem pētītajiem vienaudžu vidi raksturojošajiem faktoriem. Abi daudzfaktoru regresijas modeḷi tika izveidoti 
katrai dzimumu grupai, katram pašnāvnieciskās uzvedības veidam atsevišşki, kopā veidojot 8 modelıus (sk. 3.6.-3.9. tab.).

Reti/nekad saņemts vienaudžu emocionālais atbalsts pēc samērošanas modelī 1 zēniem domu par pašnāvību izredzes palielina 1,3 reizes, salīdzinot ar zēniem, kuri vienaudžu emocionālo atbalstu saņem vienmēr/bieži, taču pēc samērošanas modelī 2 saistība vairs nebija statistiski nozīmīga. Tāpat zēniem domu par pašnāvību saistība ar dažreiz saņemtu vienaudžu emocionālo atbalstu gan vienfaktora analīzē, gan pēc samērošanas modelī 1 un modelī 2 nav statistiski nozīmīga. Savukārt meiteņu vidū reti/nekad saṇemts vienaudžu emocionālais atbalsts pēc samērošanas modelī 1 domu par pašnāvību izredzes palielina 1,7 reizes, dažreiz saņemts vienaudžu emocionālais atbalsts 1,4 reizes, bet pēc samērošanas modelī 2 izredzes domām par pašnāvību ir attiecīgi 1,5 un 1,3 reizes augstākas, salīdzinot ar meitenēm, kuras vienaudžu emocionālo atbalstu saņem vienmēr/bieži (sk. 3.6.-3.7. tab.).

Saistībā ar pašnāvības mēginājumu reti/nekad un dažreiz saņemts vienaudžu emocionālais atbalsts zēniem pašnāvības mēǵinājuma izredzes statistiski nozīmīgi nepalielina ne vienfaktora analīzēe ne pēc samērošanas modelī 1, ne pēc samērošanas modelī 2. Savukārt meiteņu vidū reti/nekad saņemts vienaudžu emocionālais atbalsts pēc samērošanas modelī 1 pašnāvības mēginājuma izredzes palielina gandrīz divas reizes $(\mathrm{OR}=1,9)$, salīdzinot ar meitenēm, kuras vienaudžu emocionālo atbalstu saņem vienmēr/bieži, dažreiz saņemts vienaudžu emocionālais atbalsts pašnāvības mēginājuma izredzes statistiski nozīmīgi nepalielina. Pēc samērošanas modelī 2 meitenēm 1,6 reizes lielākas izredzes pašnāvības mēǵginājumam vērojamas reti/nekad saṇemta vienaudžu emocionālā atbalsta gadījumā, bet attiecībā uz kategoriju "dažreiz" saistība nav statistiski nozīmīga (sk. 3.8.-3.9. tab.).

Pašnāvnieciska pieredze vienaudžu vidū pēc samērošanas modelī 1 zēniem domu par pašnāvību izredzes palielina gandrīz astoṇas reizes $(\mathrm{OR}=$ 
7,9), bet pēc samērošanas modelī $2-7,7$ reizes, salīdzinot ar zēniem bez pašnāvnieciskas pieredzes vienaudžu vidū. Meiteņu vidū pēc samērošanas modelī 1 pašnāvnieciska pieredze vienaudžu vidū domu par pašnāvību izredzes palielina 3,5 reizes, bet pēc samērošanas modelī $2-3,3$ reizes, salīdzinot ar meitenēm bez pašnāvnieciskas pieredzes vienaudžu vidū (sk. 3.6.-3.7. tab.).

Saistībā ar pašnāvības mēginājumiem pašnāvnieciska pieredze vienaudžu vidū pēc samērošanas modelī 1 zēniem pašnāvības mēǵinājuma izredzes palielina gandrīz septiņas reizes $(\mathrm{OR}=6,8)$, bet pēc samērošanas modelī 2 - 6,5 reizes, salīdzinot ar zēniem bez pašnāvnieciskas pieredzes vienaudžu vidū. Meiteņu vidū pēc samērošanas modelī 1 pašnāvnieciska pieredze vienaudžu vidū pašnāvības mēǵinājuma izredzes palielina gandrīz piecas reizes $(\mathrm{OR}=4,8)$, bet pēc samērošanas modelī $2-4,5$ reizes, salīdzinot ar meitenēm bez pašnāvnieciskas pieredzes vienaudžu vidū (sk. 3.8.-3.9. tab.).

Vienmēr/bieži piedzīvota vienaudžu ņirgāšanās skolā pēc samērošanas modelī 1 zēniem domu par pašnāvību izredzes palielina četras reizes, bet zēniem, kuri vienaudžu ņirgāšanos piedzīvojuši dažreiz - 1,5 reizes, pēc samērošanas modelī 2 izredzes domām par pašnāvību ir attiecīgi 3,7 un 1,5 reizes augstākas, salīdzinot ar zēniem, kuri vienaudžu ņirgāšanos skolā nav piedzīvojuši. Savukārt meiteņu vidū vienmēr/bieži piedzīvota vienaudžu ņirgāšanās skolā pēc samērošanas modelī 1 domu par pašnāvību izredzes palielina 3,1 reizi, dažreiz piedzīvota vienaudžu ņirgāšanās - gandrīz divas reizes $(\mathrm{OR}=1,8)$, bet pēc samērošanas modelī 2 izredzes domām par pašnāvību ir attiecīgi 2,5 un 1,6 reizes augstākas, salīdzinot ar meitenēm, kuras vienaudžu ņirgāăšnos skolā nav piedzīvojušas (sk. 3.6.-3.7. tab.).

Saistībā ar pašnāvības mēǵinājumiem vienmēr/bieži piedzīvota vienaudžu ņirgāšanās skolā pēc samērošanas modelī 1 pašnāvības mēǵinājuma izredzes zēniem palielina gandrīz četras reizes $(\mathrm{OR}=3,8)$, savukārt zēniem, kuri emocionālo vardarbību piedzīvojuši dažreiz - gandrīz divas reizes $(\mathrm{OR}=$ 
1,8), bet pēc samērošanas modelī 2 izredzes pašnāvības mēǵinājumam ir attiecīgi 3,1 un 1,7 reizes augstākas, salīdzinot ar zēniem, kuri vienaudžu ņirgāšanos skolā nav piedzīvojuši. Savukārt meitenu vidū vienmēr/bieži piedzīvota vienaudžu ņirgāšanās skolā pēc samērošanas modelī 1 pašnāvības mēǵinājuma izredzes palielina trīs reizes, dažreiz piedzīvota vienaudžu ņirgāšanās - gandrīz divas reizes $(\mathrm{OR}=1,9)$, bet pēc samērošanas modelī 2 izredzes pašnāvības mēginājumam ir attiecīgi 2,3 un 1,7 reizes augstākas, salīdzinot ar meitenēm, kuras vienaudžu ņirgāšanos skolā nav piedzīvojušas (sk. 3.8.-3.9. tab.).

3.6. tabula

Daudzfaktoru loğistiskās regresijas modeḷi pusaudžu domu par pašnāvību saistībai ar vienaudžu vidi raksturojošiem faktoriem zēniem

\begin{tabular}{|c|c|c|c|c|}
\hline \multirow{2}{*}{ Faktors } & \multicolumn{2}{|c|}{ Modelis $1 *$} & \multicolumn{2}{|c|}{ Modelis $2^{* *}$} \\
\hline & OR $(95 \% \mathrm{TI})$ & $\mathrm{p}$ & OR $(95 \% \mathrm{TI})$ & $\mathrm{p}$ \\
\hline \multicolumn{5}{|c|}{ Vienaudžu emocionālais atbalsts } \\
\hline Reti/nekad & $1,3(1,0-1,8)$ & $\mathrm{p}<0,05$ & $1,3(0,9-1,8)$ & $p>0,05$ \\
\hline Dažreiz & $0,8(0,6-1,1)$ & $\mathrm{p}>0,05$ & $0,9(0,7-1,2)$ & $p>0,05$ \\
\hline Vienmēr/bieži & 1,0 & & 1,0 & \\
\hline \multicolumn{5}{|c|}{ Pašnāvnieciska pieredze vienaudžu vidū } \\
\hline $\mathrm{Jā}$ & $7,9(6,3-9,9)$ & $\mathrm{p}<0,001$ & $7,7(6,1-9,7)$ & $\mathrm{p}<0,001$ \\
\hline $\mathrm{Ne}$ & 1,0 & & 1,0 & \\
\hline \multicolumn{5}{|c|}{ Vienaudžu ṇirgāăsanās skolā } \\
\hline Vienmēr/bieži & $4,0(2,9-5,6)$ & $\mathrm{p}<0,001$ & $3,7(2,6-5,4)$ & $\mathrm{p}<0,001$ \\
\hline Dažreiz & $1,5(1,2-2,0)$ & $\mathrm{p}<0,05$ & $1,5(1,1-1,9)$ & $\mathrm{p}<0,05$ \\
\hline Nekad & 1,0 & & 1,0 & \\
\hline
\end{tabular}

* veikta katra faktora samērošana ar respondenta vecumu un ǵimenes materiālo stāvokli ** veikta katra faktora samērošana ar respondenta vecumu, ǵimenes materiālo stāvokli un savstarpēji ar pētîtajiem vienaudžu vidi raksturojošajiem faktoriem 
Daudzfaktoru loǵistiskās regresijas modeḷi pusaudžu domu par pašnāvību saistībai ar vienaudžu vidi raksturojošiem faktoriem meitenēm

\begin{tabular}{|c|c|c|c|c|}
\hline \multirow{2}{*}{ Faktors } & \multicolumn{2}{|c|}{ Modelis $1 *$} & \multicolumn{2}{|c|}{ Modelis $2 * *$} \\
\hline & OR $(95 \% \mathrm{TI})$ & $\mathrm{p}$ & OR $(95 \% \mathrm{TI})$ & $\mathrm{p}$ \\
\hline \multicolumn{5}{|c|}{ Vienaudžu emocionālais atbalsts } \\
\hline Reti/nekad & $1,7(1,3-2,4)$ & $\mathrm{p}<0,05$ & $1,5(1,1-2,1)$ & $\mathrm{p}<0,05$ \\
\hline Dažreiz & $1,4(1,1-1,7)$ & $\mathrm{p}<0,05$ & $1,3(1,0-1,7)$ & $\mathrm{p}<0,05$ \\
\hline Vienmēr/bieži & 1,0 & & 1,0 & \\
\hline \multicolumn{5}{|c|}{ Pašnāvnieciska pieredze vienaudžu vidū } \\
\hline $\mathrm{Jā}$ & $3,5(2,9-4,1)$ & $\mathrm{p}<0,001$ & $3,3(2,8-3,9)$ & $\mathrm{p}<0,001$ \\
\hline $\mathrm{Ne}$ & 1,0 & & 1,0 & \\
\hline \multicolumn{5}{|c|}{ Vienaudžu ṇirgāšanās skolā } \\
\hline Vienmēr/bieži & $3,1(2,3-4,2)$ & $\mathrm{p}<0,001$ & $2,5(1,8-3,5)$ & $\mathrm{p}<0,001$ \\
\hline Dažreiz & $1,8(1,5-2,2)$ & $\mathrm{p}<0,001$ & $1,6(1,4-2,0)$ & $\mathrm{p}<0,001$ \\
\hline Nekad & 1,0 & & 1,0 & \\
\hline
\end{tabular}

* veikta katra faktora samērošana ar respondenta vecumu un ǵimenes materiālo stāvokli

** veikta katra faktora samērošana ar respondenta vecumu, ǵimenes materiālo stāvokli un savstarpēji ar pētītajiem vienaudžu vidi raksturojošajiem faktoriem 
3.8. tabula

Daudzfaktoru loǵistiskās regresijas modeḷi pusaudžu pašnāvības mēǵinājumu saistībai ar vienaudžu vidi raksturojošiem faktoriem zēniem

\begin{tabular}{|c|c|c|c|c|}
\hline \multirow{2}{*}{ Faktors } & \multicolumn{2}{|c|}{ Modelis $1 *$} & \multicolumn{2}{|c|}{ Modelis $2 * *$} \\
\hline & OR $(95 \% \mathrm{TI})$ & $\mathrm{p}$ & OR $(95 \% \mathrm{TI})$ & $\mathrm{p}$ \\
\hline \multicolumn{5}{|c|}{ Vienaudžu emocionālais atbalsts } \\
\hline Reti/nekad & $1,3(0,9-1,9)$ & $\mathrm{p}>0,05$ & $1,2(0,8-1,9)$ & $\mathrm{p}>0,05$ \\
\hline Dažreiz & $0,9(0,6-1,4)$ & $\mathrm{p}>0,05$ & $1,0(0,7-1,5)$ & $p>0,05$ \\
\hline Vienmēr/bieži & 1,0 & & 1,0 & \\
\hline \multicolumn{5}{|c|}{ Pašnāvnieciska pieredze vienaudžu vidū } \\
\hline $\mathrm{Jā}$ & $6,8(5,1-9,2)$ & $\mathrm{p}<0,001$ & $6,5(4,7-8,8)$ & $\mathrm{p}<0,001$ \\
\hline $\mathrm{Ne \overline {e }}$ & 1,0 & & 1,0 & \\
\hline \multicolumn{5}{|c|}{ Vienaudžu ṇirgāšanās skolāa } \\
\hline Vienmēr/bieži & $3,8(2,4-6,0)$ & $\mathrm{p}<0,001$ & $3,1(1,9-5,1)$ & $\mathrm{p}<0,001$ \\
\hline Dažreiz & $1,8(1,2-2,5)$ & $\mathrm{p}<0,05$ & $1,7(1,1-2,4)$ & $\mathrm{p}<0,05$ \\
\hline Nekad & 1,0 & & 1,0 & \\
\hline
\end{tabular}

* veikta katra faktora samērošana ar respondenta vecumu un ǵimenes materiālo stāvokli ** veikta katra faktora samērošana ar respondenta vecumu, ǵimenes materiālo stāvokli un savstarpēji ar pētītajiem vienaudžu vidi raksturojošajiem faktoriem 
Daudzfaktoru loğistiskās regresijas modeḷi pusaudžu pašnāvības mēgeinājumu saistībai ar vienaudžu vidi raksturojošiem faktoriem meitenēm

\begin{tabular}{|c|c|c|c|c|}
\hline \multirow{2}{*}{ Faktors } & \multicolumn{2}{|c|}{ Modelis $1 *$} & \multicolumn{2}{|c|}{ Modelis $2 * *$} \\
\hline & OR $(95 \% \mathrm{TI})$ & $\mathrm{p}$ & OR $(95 \% \mathrm{TI})$ & $\mathrm{p}$ \\
\hline \multicolumn{5}{|c|}{ Vienaudžu emocionālais atbalsts } \\
\hline Reti/nekad & $1,9(1,3-2,7)$ & $\mathrm{p}<0,05$ & $1,6(1,1-2,4)$ & $\mathrm{p}<0,05$ \\
\hline Dažreiz & $1,3(0,9-1,7)$ & $\mathrm{p}>0,05$ & $1,2(0,9-1,7)$ & $\mathrm{p}>0,05$ \\
\hline Vienmēr/bieži & 1,0 & & 1,0 & \\
\hline \multicolumn{5}{|c|}{ Pašnāvnieciska pieredze vienauď̆u vid̄̄ } \\
\hline Jā & $4,8(3,8-6,0)$ & $\mathrm{p}<0,001$ & $4,5(3,6-5,7)$ & $\mathrm{p}<0,001$ \\
\hline $\mathrm{Ne}$ & 1,0 & & 1,0 & \\
\hline \multicolumn{5}{|c|}{ Vienaudžu ṇirgā̄̌sanās skolā } \\
\hline Vienmēr/bieži & $3,0(2,1-4,4)$ & $\mathrm{p}<0,001$ & $2,3(1,6-3,5)$ & $\mathrm{p}<0,001$ \\
\hline Dažreiz & $1,9(1,5-2,4)$ & $\mathrm{p}<0,001$ & $1,7(1,3-2,2)$ & $\mathrm{p}<0,001$ \\
\hline Nekad & 1,0 & & 1,0 & \\
\hline
\end{tabular}

* veikta katra faktora samērošana ar respondenta vecumu un gimenes materiālo stāvokli ** veikta katra faktora samērošana ar respondenta vecumu, ǵimenes materiālo stāvokli un savstarpēji ar pētittajiem vienaudžu vidi raksturojošajiem faktoriem

\subsection{Pašnāvnieciskā uzvedība un individuālie faktori}

Pusaudžu pašnāvnieciskās uzvedības saistība ar individuālajiem faktoriem analizēta daudzfaktoru regresijas modeḷos. Modelī 1 veikta katra pētītā faktora samērošana ar respondenta vecumu un ǵimenes materiālo stāvokli. Modelī 2 veikta faktoru samērošana ar respondenta vecumu, ǵimenes materiālo stāvokli un savstarpēji ar citiem pētītajiem individuālajiem faktoriem. Abi daudzfaktoru regresijas modȩ̣i tika izveidoti katrai dzimumu grupai, katram pašnāvnieciskās uzvedības veidam atsevišḳi, kopā veidojot 8 modeḷus (sk. 3.10.-3.13. tab.). 
Augsts depresijas simptomu līmenis pēc samērošanas modelī 1 zēniem domu par pašnāvību izredzes palielina gandrīz sešas reizes $(\mathrm{OR}=5,9)$, savukārt vidēji augsts depresijas simptomu līmenis - 2,1 reizi, bet pēc samērošanas modelī 2 izredzes domām par pašnāvību ir attiecīgi 3,7 un 1,7 reizes augstākas, salīdzinot ar zēniem, kuru depresijas simptomu līmenis ir zems. Savukārt meiteņu vidū augsts depresijas simptomu līmenis pēc samērošanas modelī 1 domu par pašnāvību izredzes palielina 5,1 reizi, vidēji augsts depresijas simptomu līmenis $-2,1$ reizi, bet pēc samērošanas modelī 2 izredzes domām par pašnāvību ir attiecīgi trīs un 1,7 reizes augstākas, salīdzinot ar meitenēm, kuru depresijas simptomu līmenis ir zems (sk. 3.10.-3.11. tab.).

Saistībā ar pašnāvības mēǵinājumiem augsts depresijas simptomu līmenis pēc samērošanas modelī 1 zēniem pašnāvības mēǵinājuma izredzes palielina gandrīz septiņas reizes $(\mathrm{OR}=6,8)$, savukārt vidēji augsts depresijas simptomu līmenis - 2,4 reizes, bet pēc samērošanas modelī 2 izredzes pašnāvības mēǵinājumam ir attiecīgi 3,5 un divas reizes augstākas, salīdzinot ar zēniem, kuru depresijas simptomu līmenis ir zems. Savukārt meiteņu vidū augsts depresijas simptomu līmenis pēc samērošanas modelī 1 pašnāvības mēǵinājuma izredzes palielina gandrīz piecas reizes $(\mathrm{OR}=4,8)$, vidēji augsts depresijas simptomu līmenis $-2,1$ reizi, bet pēc samērošanas modelī 2 izredzes pašnāvības mēginājumam ir attiecīgi gandrīz trīs $(\mathrm{OR}=2,8)$ un 1,7 reizes augstākas, salīdzinot ar meitenēm, kuru depresijas simptomu līmenis ir zems (sk. 3.12.-3.13. tab.).

Zems pašcieņas līmenis pēc samērošanas modelī 1 zēniem domu par pašnāvību izredzes palielina gandrīz sešas reizes $(\mathrm{OR}=5,9)$, savukārt vidēji zems pašcieņas līmenis - 2,5 reizes, bet pēc samērošanas modelī 2 izredzes domām par pašnāvību ir attiecīgi gandrīz četras $(\mathrm{OR}=3,8)$ un divas reizes augstākas, salīdzinot ar zēniem, kuru pašcieņas līmenis ir augsts. Savukārt meiteņu vidū zems pašcieņas līmenis pēc samērošanas modelī 1 domu par 
pašnāvību izredzes palielina 3,7 reizes, vidēji zems pašcieņas līmenis - 1,7 reizes, bet pēc samērošanas modelī 2 izredzes domām par pašnāvību ir attiecīgi 2,3 un 1,4 reizes augstākas, salīdzinot ar meitenēm, kuru pašcieņas līmenis ir augsts (sk. 3.10.-3.11. tab.).

Saistībā ar pašnāvības mēgeinājumiem zems pašcieņas līmenis pēc samērošanas modelī 1 zēniem pašnāvības mēǵinājuma izredzes palielina astoṇas reizes, savukārt vidēji zems pašcieņas līmenis - gandrīz trīs reizes $(\mathrm{OR}=2,9)$, bet pēc samērošanas modelī 2 izredzes pašnāvības mēgeinājumam ir attiecīgi 5,1 un 2,4 reizes augstākas, salīdzinot ar zēniem, kuru pašcieņas līmenis ir augsts. Savukārt meiteņu vidū zems pašcieņas līmenis pēc samērošanas modelī 1 pašnāvības mēǵinājuma izredzes palielina 3,7 reizes, vidēji zems pašcieņas līmenis - divas reizes, bet pēc samērošanas modelī 2 izredzes pašnāvības mēginājumam ir attiecīgi 2,3 un 1,6 reizes augstākas, salīdzinot ar meitenēm, kuru pašcieņas līmenis ir augsts (sk. 3.12.-3.13. tab.).

Neapmierinātība ar veselības stāvokli pēc samērošanas modelī 1 zēniem domu par pašnāvību izredzes palielina 2,7 reizes, savukārt vidēja apmierinātība - gandrīz divas reizes $(\mathrm{OR}=1,9)$, salīdzinot ar zēniem, kuri ar savu veselības stāvokli ir apmierināti, taču pēc samērošanas modelī 2 domu par pašnāvību saistība ar neapmierinātību vai vidēju apmierinātîbu ar veselības stāvokli zēniem vairs nav statistiski nozīmīga. Savukārt meiteņu vidū neapmierinātība ar veselības stāvokli pēc samērošanas modelī 1 domu par pašnāvību izredzes palielina 3,5 reizes, vidēja apmierinātība $-2,1$ reizi, bet pēc samērošanas modelī 2 izredzes domām par pašnāvību ir attiecīgi 2,1 un 1,5 reizes augstākas, salīdzinot ar meitenēm, kuras ar savu veselības stāvokli ir apmierinātas (sk. 3.10 --3.11. tab.).

Saistībā ar pašnāvības mēginājumiem neapmierinātība ar veselības stāvokli pēc samērošanas modelī 1 zēniem pašnāvības mēg̣inājuma izredzes palielina 4,6 reizes, savukārt vidēja apmierinātība - 2,6 reizes, salīdzinot ar 
zēniem, kuri ar savu veselības stāvokli ir apmierināti, savukārt pēc samērošanas modelī 2 zēniem, kuri ir neapmierināti ar savu veselības stāvokli, vērojamas 2,1 reizi lielākas izredzes pašnāvības mēginājumam, taču attiecībā uz vidēju apmierinātību ar veselības stāvokli zēniem saistība nav statistiski nozīmīga. Savukārt meiteņu vidū neapmierinātība ar veselības stāvokli pēc samērošanas modelī 1 pašnāvības mēǵinājuma izredzes palielina 3,5 reizes, vidēja apmierinātība - gandrīz divas reizes $(\mathrm{OR}=1,8)$, bet pēc samērošanas modelī 2 izredzes pašnāvības mēǵinājumam neapmierinātības ar veselības pašvērtējumu gadījumā ir 2,1 reizi augstākas nekā meitenēm, kuras ar veselības stāvokli ir apmierinātas, taču vidējas apmierinātības ar veselības stāvokli gadījumā statistiski nozīmīgi lielākas izredzes pašnāvības mēg̣inājumam meitenēm netika konstatētas (sk. 3.12.-3.13. tab.).

Riskanta alkohola lietošana 3 un vairāk reizes dzīves laikā pēc samērošanas modelī 1 zēniem domu par pašnāvību izredzes palielina gandrīz divas reizes $(\mathrm{OR}=1,8)$, savukārt riskanta alkohola lietošana 1-2 reizes 1,3 reizes, salīdzinot ar zēniem, kuri dzīves laikā riskanti alkoholu nav lietojuši, taču pēc samērošanas modelī 2, domu par pašnāvību saistība ar riskantu alkohola lietošanu zēniem vairs nav statistiski nozīmīga. Savukārt meiteņu vidū riskanta alkohola lietošana 3 un vairāk reizes dzīves laikā pēc samērošanas modelī 1 domu par pašnāvību izredzes palielina gandrīz trīs reizes $(\mathrm{OR}=2,9)$, riskanta alkohola lietošana $1-2$ reizes $-1,7$ reizes, bet pēc samērošanas modelī 2 izredzes domām par pašnāvību ir attiecīgi gandrīz divas $(\mathrm{OR}=1,8)$ un 1,3 reizes augstākas, salīdzinot ar meitenēm, kuras dzīves laikā riskanti alkoholu nav lietojušas (sk. 3.10.-3.11. tab.).

Saistībā ar pašnāvības mēǵinājumiem riskanta alkohola lietošana 3 un vairāk reizes dzīves laikā pēc samērošanas modelī 1 zēniem pašnāvības mēǵinājuma izredzes palielina divas reizes, salīdzinot ar zēniem, kuri dzīves laikā riskanti alkoholu nav lietojuši, pašnāvības mēǵinājuma saistība ar riskantu 
alkohola lietošanu 1-2 reizes zēniem nav statistiski nozīmīga. Pēc samērošanas modelī 2 pašnāvības mēgeinājuma saistība ar riskantu alkohola lietošanu zēniem vairs nav statistiski nozīmīga. Savukārt meiteņu vidū riskanta alkohola lietošana 3 un vairāk reizes dzīves laikā pēc samērošanas modelī 1 pašnāvības mēǵinājuma izredzes palielina gandrīz trīs reizes $(\mathrm{OR}=2,9)$, riskanta alkohola lietošana 1-2 reizes - 2,3 reizes, bet pēc samērošanas modelī 2 izredzes pašnāvības mēǵinājumam meitenēm abās riskanta alkohola lietošanās kategorijās ir gandrīz divas reizes $(\mathrm{OR}=1,8)$ augstākas, salīdzinot ar meitenēm, kuras dzīves laikā riskanti alkoholu nav lietojušas (sk. 3.12.3.13. tab.).

Ikdienas smēḳēšana pēc samērošanas modelī 1 zēniem domu par pašnāvību izredzes palielina gandrīz divas reizes $(\mathrm{OR}=1,9)$, bet pēc samērošanas modelī $2-1,3$ reizes, salīdzinot ar zēniem, kuri ikdienā nesmēḳē. Meiteņu vidū pēc samērošanas modelī 1 ikdienas smēķēšana domu par pašnāvību izredzes palielina 2,1 reizi, bet pēc samērošanas modelī 2 1,4 reizes, salīdzinot ar meitenēm, kuras ikdienā nesmēḳēe (sk. 3.10.-3.11. tab.).

Saistībā ar pašnāvības mēǵinājumu Ikdienas smēķēšana pēc samērošanas modelī 1 zēniem pašnāvības mēǵinājuma izredzes palielina gandrīz trīs reizes $(\mathrm{OR}=2,8)$, bet pēc samērošanas modelī $2-2,3$ reizes, salīdzinot ar zēniem, kuri ikdienā nesmēḳēe. Meiteņu vidū pēc samērošanas modelī 1 ikdienas smēḳēěana pašnāvības mēg̣inājuma izredzes palielina 2,5 reizes, bet pēc samērošanas modelī 2 - gandrīz divas reizes $(\mathrm{OR}=1,8)$, salīdzinot ar meitenēm, kuras ikdienā nesmēķēe (sk. 3.12.-3.13. tab.).

Narkotiku lietošana dzīves laikā pēc samērošanas modelī 1 zēniem domu par pašnāvību izredzes palielina 2,2 reizes, bet pēc samērošanas modelī 2 - 1,4 reizes, salīdzinot ar zēniem, kuri marihuānu/hašišu, amfetamīnu, LSD/citus halucinogēnus, kreku, kokāinu, heroīnu, ekstaz̄i un/vai spice nav lietojuši. Meiteņu vidū pēc samērošanas modelī 1 narkotiku lietošana dzīves 
laikā domu par pašnāvību izredzes palielina 2,1 reizi, bet pēc samērošanas modelī 2 - 1,4 reizes, salīdzinot ar meitenēm, kuras marihuānu/hašišu, amfetamīnu, LSD/citus halucinogēnus, kreku, kokaīnu, heroīnu, ekstazī un/vai spice dzīves laikā nav lietojušas (sk. 3.10.-3.11. tab.).

Saistībā ar pašnāvības mēǵinājumu narkotiku lietošana dzīves laikā pēc samērošanas modelī 1 zēniem pašnāvības mēgeinājuma izredzes palielina trīs reizes, bet pēc samērošanas modelī 2 - 1,7 reizes, salīdzinot ar zēniem, kuri marihuānu/hašišu, amfetamīnu, LSD/citus halucinogēnus, kreku, kokaīnu, heroīnu, ekstazī un/vai spice nav lietojuši. Meiteņu vidū pēc samērošanas modelī 1 narkotiku lietošana dz̄ives laikā pašnāvības mēǵinājuma izredzes palielina 2,1 reizi, salīdzinot ar meitenēm, kuras marihuānu/hašišu, amfetamīnu, LSD/citus halucinogēnus, kreku, kokaīnu, heroīnu, ekstazī un/vai spice dzīves laikā nav lietojušas, taču pēc samērošanas modelī 2 saistība ar pašnāvības mēǵinājumu vairs nav statistiski nozīmīga (sk. 3.12.-3.13. tab.). 
Daudzfaktoru loǵistiskās regresijas modelii pusaudžu domu par pašnāvību saistībai ar individuālajiem faktoriem zēniem

\begin{tabular}{|c|c|c|c|c|}
\hline \multirow{2}{*}{ Faktors } & \multicolumn{2}{|c|}{ Modelis $1 *$} & \multicolumn{2}{|c|}{ Modelis $2 * *$} \\
\hline & OR $(95 \% \mathrm{TI})$ & $\mathrm{p}$ & OR $(95 \% \mathrm{TI})$ & $\mathrm{p}$ \\
\hline \multicolumn{5}{|c|}{ Depresijas simptomu līmenis } \\
\hline Augsts & $5,9(4,5-7,8)$ & $\mathrm{p}<0,001$ & $3,7(2,7-5,1)$ & $\mathrm{p}<0,001$ \\
\hline Vidēji augsts & $2,1(1,6-2,7)$ & $\mathrm{p}<0,001$ & $1,7(1,3-2,3)$ & $\mathrm{p}<0,001$ \\
\hline Zems & 1,0 & & 1,0 & \\
\hline \multicolumn{5}{|l|}{ Pašcienas līmenis } \\
\hline Zems & $5,9(4,4-7,8)$ & $\mathrm{p}<0,001$ & $3,8(2,8-5,2)$ & $\mathrm{p}<0,001$ \\
\hline Vidēji zems & $2,5(1,9-3,5)$ & $\mathrm{p}<0,001$ & $2,0(1,4-2,7)$ & $\mathrm{p}<0,001$ \\
\hline Augsts & 1,0 & & 1,0 & \\
\hline \multicolumn{5}{|c|}{ Apmierinātība ar veselības stāvokli } \\
\hline Neapmierināts & $2,7(1,8-4,0)$ & $\mathrm{p}<0,001$ & $1,3(0,8-2,0)$ & $\mathrm{p}>0,05$ \\
\hline Vidēji apmierināts & $1,9(1,4-2,7)$ & $\mathrm{p}<0,001$ & $1,1(0,7-1,5)$ & $\mathrm{p}>0,05$ \\
\hline Apmierināts & 1,0 & & 1,0 & \\
\hline \multicolumn{5}{|c|}{ Riskanta alkohola lietošana } \\
\hline 3 un vairāk reizes & $1,8(1,4-2,4)$ & $\mathrm{p}<0,001$ & $1,3(0,9-1,8)$ & $\mathrm{p}>0,05$ \\
\hline $1-2$ reizes & $1,3(1,0-1,8)$ & $\mathrm{p}<0,05$ & $1,1(0,8-1,6)$ & $\mathrm{p}>0,05$ \\
\hline $\mathrm{Ne}$ & 1,0 & & 1,0 & \\
\hline \multicolumn{5}{|l|}{ Ikdienas smēkēěšana } \\
\hline $\mathrm{Jā}$ & $1,9(1,6-2,4)$ & $\mathrm{p}<0,001$ & $1,3(1,0-1,7)$ & $\mathrm{p}<0,05$ \\
\hline $\mathrm{Ne}$ & 1,0 & & 1,0 & \\
\hline \multicolumn{5}{|l|}{ Narkotiku lietošana } \\
\hline Jā & $2,2(1,7-2,7)$ & $\mathrm{p}<0,001$ & $1,4(1,1-1,9)$ & $\mathrm{p}<0,05$ \\
\hline $\mathrm{Ne \overline {e }}$ & 1,0 & & 1,0 & \\
\hline
\end{tabular}

* veikta katra faktora samērošana ar respondenta vecumu un ǵimenes materiālo stāvokli ** veikta katra faktora samērošana ar respondenta vecumu, ǵimenes materiālo stāvokli un savstarpēji ar pētītajiem individuālajiem faktoriem 
Daudzfaktoru loǵistiskās regresijas modeli pusaudžu domu par pašnāvību saistībai ar individuālajiem faktoriem meitenēm

\begin{tabular}{|c|c|c|c|c|}
\hline \multirow{2}{*}{ Faktors } & \multicolumn{2}{|c|}{ Modelis $1 *$} & \multicolumn{2}{|c|}{ Modelis $2 * *$} \\
\hline & OR $(95 \% \mathrm{TI})$ & $\mathrm{p}$ & OR $(95 \% \mathrm{TI})$ & $\mathrm{p}$ \\
\hline \multicolumn{5}{|c|}{ Depresijas simptomu līmenis } \\
\hline Augsts & $5,1(4,0-6,4)$ & $\mathrm{p}<0,001$ & $3,0(2,4-3,9)$ & $\mathrm{p}<0,001$ \\
\hline Vidēji augsts & $2,1(1,7-2,7)$ & $\mathrm{p}<0,001$ & $1,7(1,3-2,2)$ & $\mathrm{p}<0,001$ \\
\hline Zems & 1,0 & & 1,0 & \\
\hline \multicolumn{5}{|l|}{ Pašcieṇas līmenis } \\
\hline Zems & $3,7(3,0-4,5)$ & $\mathrm{p}<0,001$ & $2,3(1,8-2,9)$ & $\mathrm{p}<0,001$ \\
\hline Vidēji zems & $1,7(1,4-2,2)$ & $\mathrm{p}<0,001$ & $1,4(1,1-1,7)$ & $\mathrm{p}<0,05$ \\
\hline Augsts & 1,0 & & 1,0 & \\
\hline \multicolumn{5}{|c|}{ Apmierinātība ar veselības stāvokli } \\
\hline Neapmierināts & $3,5(2,8-4,5)$ & $\mathrm{p}<0,001$ & $2,1(1,6-2,8)$ & $\mathrm{p}<0,001$ \\
\hline Vidēji apmierināts & $2,1(1,7-2,6)$ & $\mathrm{p}<0,001$ & $1,5(1,2-1,9)$ & $\mathrm{p}<0,05$ \\
\hline Apmierināts & 1,0 & & 1,0 & \\
\hline \multicolumn{5}{|c|}{ Riskanta alkohola lietošana } \\
\hline 3 un vairāk reizes & $2,9(2,3-3,6)$ & $\mathrm{p}<0,001$ & $1,8(1,4-2,4)$ & $\mathrm{p}<0,001$ \\
\hline $1-2$ reizes & $1,7(1,4-2,1)$ & $\mathrm{p}<0,001$ & $1,3(1,0-1,7)$ & $\mathrm{p}<0,05$ \\
\hline $\mathrm{Ne}$ & 1,0 & & 1,0 & \\
\hline \multicolumn{5}{|l|}{ Ikdienas smēḳēšana } \\
\hline $\mathrm{J} \overline{\mathrm{a}}$ & $2,1(1,8-2,6)$ & $\mathrm{p}<0,001$ & $1,4(1,2-1,8)$ & $\mathrm{p}<0,05$ \\
\hline $\mathrm{Ne \overline {e }}$ & 1,0 & & 1,0 & \\
\hline \multicolumn{5}{|l|}{ Narkotiku lietošana } \\
\hline $\mathrm{Jā}$ & $2,1(1,8-2,6)$ & $\mathrm{p}<0,001$ & $1,4(1,1-1,7)$ & $\mathrm{p}<0,05$ \\
\hline $\mathrm{Ne}$ & 1,0 & & 1,0 & \\
\hline
\end{tabular}

* veikta katra faktora samērošana ar respondenta vecumu un ǵimenes materiālo stāvokli ** veikta katra faktora samērošana ar respondenta vecumu, ǵimenes materiālo stāvokli un savstarpēji ar pētītajiem individuālajiem faktoriem 
Daudzfaktoru loğistiskās regresijas modeḷi pusaudžu pašnāvības mēǵinājumu saistībai ar individuālajiem faktoriem zēniem

\begin{tabular}{|c|c|c|c|c|}
\hline \multirow{2}{*}{ Faktors } & \multicolumn{2}{|c|}{ Modelis $1 *$} & \multicolumn{2}{|c|}{ Modelis 2** } \\
\hline & OR $(95 \% \mathrm{TI})$ & $\mathrm{p}$ & OR $(95 \% \mathrm{TI})$ & $\mathrm{p}$ \\
\hline \multicolumn{5}{|c|}{ Depresijas simptomu līmenis } \\
\hline Augsts & $6,8(4,7-9,9)$ & $\mathrm{p}<0,001$ & $3,5(2,3-5,5)$ & $\mathrm{p}<0,001$ \\
\hline Vidēji augsts & $2,4(1,7-3,5)$ & $\mathrm{p}<0,001$ & $2,0(1,3-3,0)$ & $\mathrm{p}<0,05$ \\
\hline Zems & 1,0 & & 1,0 & \\
\hline \multicolumn{5}{|l|}{ Pašcienas līmenis } \\
\hline Zems & $8,0(5,2-12,1)$ & $\mathrm{p}<0,001$ & $5,1(3,2-8,2)$ & $\mathrm{p}<0,001$ \\
\hline Vidēji zems & $2,9(1,8-4,6)$ & $\mathrm{p}<0,001$ & $2,4(1,4-4,0)$ & $\mathrm{p}<0,05$ \\
\hline Augsts & 1,0 & & 1,0 & \\
\hline \multicolumn{5}{|c|}{ Apmierinātība ar veselības stāvokli } \\
\hline Neapmierināts & $4,6(2,9-7,1)$ & $\mathrm{p}<0,001$ & $2,1(1,3-3,6)$ & $\mathrm{p}<0,05$ \\
\hline Vidēji apmierināts & $2,6(1,7-4,0)$ & $\mathrm{p}<0,001$ & $1,3(0,8-2,1)$ & $\mathrm{p}>0,05$ \\
\hline Apmierināts & 1,0 & & 1,0 & \\
\hline \multicolumn{5}{|c|}{ Riskanta alkohola lietošana } \\
\hline 3 un vairāk reizes & $2,0(1,4-2,8)$ & $\mathrm{p}<0,001$ & $1,0(0,7-1,6)$ & $\mathrm{p}>0,05$ \\
\hline $1-2$ reizes & $1,2(0,8-1,7)$ & $\mathrm{p}>0,05$ & $0,8(0,5-1,3)$ & $\mathrm{p}>0,05$ \\
\hline $\mathrm{Ne}$ & 1,0 & & 1,0 & \\
\hline \multicolumn{5}{|l|}{ Ikdienas smēḳēšana } \\
\hline $\mathrm{Ja}$ & $2,8(2,1-3,8)$ & $\mathrm{p}<0,001$ & $2,3(1,6-3,2)$ & $\mathrm{p}<0,001$ \\
\hline $\mathrm{Ne}$ & 1,0 & & 1,0 & \\
\hline \multicolumn{5}{|l|}{ Narkotiku lietošana } \\
\hline Jā & $3,0(2,3-4,1)$ & $\mathrm{p}<0,001$ & $1,7(1,2-2,4)$ & $\mathrm{p}<0,05$ \\
\hline $\mathrm{Ne}$ & 1,0 & & 1,0 & \\
\hline
\end{tabular}

* veikta katra faktora samērošana ar respondenta vecumu un ǵimenes materiālo stāvokli ** veikta katra faktora samērošana ar respondenta vecumu, ǵimenes materiālo stāvokli un savstarpēji ar pētītajiem individuālajiem faktoriem 
Daudzfaktoru loǵistiskās regresijas modeḷi pusaudžu pašnāvības mēğinājumu saistībai ar individuālajiem faktoriem meitenēm

\begin{tabular}{|c|c|c|c|c|}
\hline \multirow{2}{*}{ Faktors } & \multicolumn{2}{|c|}{ Modelis $1 *$} & \multicolumn{2}{|c|}{ Modelis $2 * *$} \\
\hline & OR $(95 \% \mathrm{TI})$ & $\mathrm{p}$ & OR $(95 \% \mathrm{TI})$ & $\mathrm{p}$ \\
\hline \multicolumn{5}{|c|}{ Depresijas simptomu līmenis } \\
\hline Augsts & $4,8(3,5-6,5)$ & $\mathrm{p}<0,001$ & $2,8(2,0-3,9)$ & $\mathrm{p}<0,001$ \\
\hline Vidēji augsts & $2,1(1,5-3,0)$ & $\mathrm{p}<0,001$ & $1,7(1,2-2,4)$ & $\mathrm{p}<0,05$ \\
\hline Zems & 1,0 & & 1,0 & \\
\hline \multicolumn{5}{|l|}{ Pašcieñas līmenis } \\
\hline Zems & $3,7(2,8-4,8)$ & $\mathrm{p}<0,001$ & $2,3(1,7-3,1)$ & $\mathrm{p}<0,001$ \\
\hline Vidēji zems & $2,0(1,5-2,7)$ & $\mathrm{p}<0,001$ & $1,6(1,1-2,1)$ & $\mathrm{p}<0,05$ \\
\hline Augsts & 1,0 & & 1,0 & \\
\hline \multicolumn{5}{|c|}{ Apmierinātība ar veselības stāvokli } \\
\hline Neapmierināts & $3,5(2,6-4,6)$ & $\mathrm{p}<0,001$ & $2,1(1,5-2,9)$ & $\mathrm{p}<0,001$ \\
\hline Vidēji apmierināts & $1,8(1,4-2,5)$ & $\mathrm{p}<0,001$ & $1,3(0,9-1,7)$ & $\mathrm{p}>0,05$ \\
\hline Apmierināts & 1,0 & & 1,0 & \\
\hline \multicolumn{5}{|c|}{ Riskanta alkohola lietošana } \\
\hline 3 un vairāk reizes & $2,9(2,2-3,9)$ & $\mathrm{p}<0,001$ & $1,8(1,3-2,5)$ & $\mathrm{p}<0,001$ \\
\hline $1-2$ reizes & $2,3(1,7-3,1)$ & $\mathrm{p}<0,001$ & $1,8(1,4-2,5)$ & $\mathrm{p}<0,001$ \\
\hline $\mathrm{Ne}$ & 1,0 & & 1,0 & \\
\hline \multicolumn{5}{|l|}{ Ikdienas smēḳēšana } \\
\hline $\mathrm{Ja}$ & $2,5(2,0-3,2)$ & $\mathrm{p}<0,001$ & $1,8(1,4-2,3)$ & $\mathrm{p}<0,001$ \\
\hline $\mathrm{Ne}$ & 1,0 & & 1,0 & \\
\hline \multicolumn{5}{|l|}{ Narkotiku lietošana } \\
\hline $\mathrm{Jā}$ & $2,1(1,7-2,6)$ & $\mathrm{p}<0,001$ & $1,2(0,9-1,6)$ & $\mathrm{p}>0,05$ \\
\hline $\mathrm{Ne}$ & 1,0 & & 1,0 & \\
\hline
\end{tabular}

* veikta katra faktora samērošana ar respondenta vecumu un ǵimenes materiālo stāvokli ** veikta katra faktora samērošana ar respondenta vecumu, ǵimenes materiālo stāvokli un savstarpēji ar pētītajiem individuālajiem faktoriem 


\section{DISKUSIJA}

\subsection{Pašnāvnieciskās uzvedības izplatība pusaudžu sociāldemogrāfiskajās grupās}

Promocijas darbā iegūtie rezultāti liecina, ka domas par pašnāvību dzīves laikā, jeb pārdomātu konkrētu veidu, vietu vai rīcību pašnāvības izdarīšanai atzīmējuši 15,7\% Latvijas 14-17 gadus veco pusaudžu - 11,7\% zēnu un 19,4\% meiteņu. N̦emot vērā zinātniskajā literatūrā vērojamās atšķirības domu par pašnāvību definēšanā un faktu, ka promocijas darba izstrādē izmantotais jautājums domu par pašnāvību noteikšanai konstruēts tieši aktīvu domu par pašnāvību noskaidrošanai, ir apgrūtināta iegūtās domu par pašnāvību izplatības precīza salīdzināšana ar citās valstīs iegūtajiem rezultātiem. Atbilstošā vecuma grupā veiktā pētījumā Beḷgijāa, Anglijā, Ungārijā, İrijā, Nīderlandē, Norvēgiijā un Austrālijā pēc vienotas metodoloǵijas veiktā pētījumā tika iegūts līdzịgs izplatības rādītājs - 14,6\% (9,2\% zēniem un 20,3\% meitenēm), tomēr šajā pētījumā analizētas domas par paškaitējumu, kas ietver pašnāvnieciskus aktu gan ar, gan bez vēlmes izdarīt pabeigtu pašnāvību (Madge et al., 2011). No otras puses, cilvēka, jo īpaši pusaudža, un vēl jo vairāk domu par paškaitējumu gadījumā pašnāvnieciskais nodoms var būt ambivalents, neizšķirot skaidru nodomu dzīvot vai mirt (WHO, 2014a), kas liecina arī par iespēju arī šos rādītājus izmantot salīdzinājumam, jo ir maz ticams, ka pusaudzis, atbildot uz jautājumu, ir ņēmis vērā pētnieku un zinātnieku apsvērumus par atšķirībām jēdzienu definīcijās un detalizēti analizējis savu vēlmi mirt pārdomātā pašnāvības veikšanas vietā, noteiktā veidā, vai apzinātas rīcības rezultātā. Tāpat arī iegūtie domu par pašnāvību izplatības rādītāji ir ievērojami zemāki nekā līdzịgā vecuma grupā veiktajā pêtījumā 17 Eiropas valstīs, kurā vaicāts vai respondents dzīves laikā ir domājis darīt sev pāri un iegūti teju uz pusi augstāki izplatības rādītāji - 30,8\% (20,2\% zēniem un 41,2\% 
meitenēm) (Kokkevi et al., 2012), kas, visticamāk, liecina nevis par zemākiem domu par pašnāvību izplatības rādītājiem Latvijā, bet gan par promocijas darbā izmantotās domu par pašnāvību gadījuma definīcijas salīdzinošo precizitāti, kas uzskatāma par promocijas darbā izmantotās definīcijas salīdzinošo priekšrocību.

Savukārt dzīves laikā veiktu mēgeinājumu izdarīt pašnāvību atzīmējuši $8,2 \%$ promocijas darba ietvaros analizēto $14-17$ gadus veco pusaudžu - 5,9\% zēnu un 10,2\% meiteņu. Arī attiecībā uz pašnāvības mēǵinājumu nereti zinātniskajā literatūrā vērojamas atškirīibas gadījuma definīcijās, tomēr š̄is atšḳirības nav tik izteiktas kā domu par pašnāvību gadījumā, tādēl ir vieglāk veikt salīdzinājumu starp dažādiem pētījumiem. Attiecībā uz pašnāvības mēǵinājumu būtiskākas atšķirības izplatības radītājos pētījumos iezīmējas atkarībā no tā vai veikta anonīma anketēšana, vai pusaudži uz jautājumu par pašnāvības mēǵinājumu atbildējuši tiešajās intervijās - pētījuma dati liecina, ka anonīmās anketās pusaudži par pašnāvības mēǵinājumiem ziṇo biežāk nekā tiešajās intervijās (Safer, 1997), kas liecina, ka anonīmās aptaujās pusaudži ir atklātāki par šāda veida pieredzi. Attiecīgi arī pusaudžu pašu ziņoto pašnāvības mēginājumu izplatīiba analizētajos zinātniskās literatūras avotos variē atkarībā no izmantotās pētījuma metodologiijas un analizētās pusaudžu vecuma grupas 2,9\% līdz 14,4\% kopējos izplatības rādītājos, 1,5\% līidz 8,4\% zēniem un 2,5\% līdz 17,9\% meitenēm (Kokkevi et al., 2012; Kokkevi et al., 2011; Nock et al., 2013; Joe et al., 2009; Hu et al., 2015; Zarrouq et al., 2015). Salīdzinoši precīzākais pusaudžu pašu ziņoto pašnāvības mēǵinājumu izplatības salīdzinājums ar situāciju citās valstīs iespējams, analizējot šos datus par tām valstīm, kurās arī veikts ESPAD pētījums ar iekḷautu psihosociālo moduli, t.sk. jautājumu par pusaudžu pašnāvības mēǵinājumiem. Lai arī tiek salīdzināti dati par 15-16 gadus veciem pusaudžiem, dati par 2007. gadu liecina, ka šajās 17 Eiropas valstīs vidējais pašnāvības mēǵinājuma izplatība rādītājs ir 11\% (8\% 
zēniem un 14\% meitenēm) (Hibell et al., 2009) un mediāna 10,5\% (6,9\% zēniem un 13,7\% meitenēm) (Kokkevi et al., 2012), kas liecina, ka gan kopējais izplatības rādītājs, gan izplatî̉ba abās dzimumu grupās Latvijā ir salīdzinoši zemāka, tomēr, n,emot vērā, ka šiem rādītājiem ir tendence gadu gaitā mainīties (Kokkevi et al., 2011), precīzākam salīdzinājumam būtu nepieciešami 2011. gada dati par situāciju citās valstīs.

Būtisks jautājums ir arī pašnāvības mēǵinājuma jēdziena interpretācija, jo īpaši pusaudžu vidū. Neskatoties uz faktu, ka arī daudzos citos pētījumos pašnāvības mēǵinājuma noteikšanai tiek izmantots līdzīgs jautājums, no vienas puses pašnāvības mēǵinājuma gadījuma interpretācijas mazinātu jautājuma konkretizēšana, tomēr jāṇem vērā, ka konkrētu metožu vai veidu norādīšana, iespējams, var saistīties ar atdarinošo pašnāvības mēǵinājumu risku (WHO, 2008), jo īpaši pusaudžu populācijā un jo īpaši apstākḷlos, kad tiek anketēts liels skaits pusaudžu.

Promocijas darbā iegūtie dati par pašnāvnieciskās uzvedības izplatību dzimuma grupās liecina, ka meitenes gan domas par pašnāvību, gan pašnāvības mēǵinājumus atzīmē biežāk nekā zēni - par šo faktu liecina arī teju visi analizētie zinātniskās literatūras avoti. Likumsakarīgs ir jautājums par šo atšķirību iemesliem, jo īpaši ņemot vērā faktu, ka pabeigtas pašnāvības gadu no gada biežāk izdara zēni (Šica, Pulmanis un Taube, 2017). Zinātniskajā literatūrā šī situācija tiek aprakstìta kā dzimuma paradokss (angl. - gender paradox) (Tsirigotis, Gruszczynski and Tsirigotis, 2011; Rhodes et al., 2014; Beautrais, 2002) un skaidrota ar sieviešu izteiktāku ievainojamību psihopatalogiju un psihosociālu stresoru gadījumā (Vijayakumar, 2015), kas sieviešu un meiteņu vidū ir arī izplatîtākas iepretim faktam, ka sievietes izvēlas mazāk nāvējošākas pašnāvības izdarǐšanas metodes, kas vairāk piesaista uzmanību sievietes psihoemocionālajām ciešanām un mazāk ir saistītas ar reālu vēlmi mirt. Citi skaidrojumi saistīti arī ar sieviešu izteiktāko vēlmi izpaust savas problēmas un 
meklēt palīdzību, piemēram, apmeklēt ārstu vai zvanīt uz krīzes tālruniem (Beautrais, 2002).

Tāpat promocijas darbā noskaidrots, ka augstāka domu par pašnāvību izplatība ir vecākajā analizētajā pusaudžu vecuma grupā, proti, 16-17 gadi, salīdzinot ar vecuma grupu 14-15 gadi. Domu par pašnāvību un pašnāvības mēǵinājumu izplatības pieauguma tendence līdz ar pusaudža vecuma grupas palielināšanos novērota arī citos pētījumos (Zubrick et al., 2016; WolitzkyTaylor et al., 2010) (promocijas darba ietvaros atškirīības pašnāvības mēǵinājumu izplatībā vecuma grupās nebija statistiski nozīmīgas), taču jāṇem vērā, ka izvēlēto pašnāvnieciskās uzvedības izplatības rādītāju - mūža prevalenci teorētiski var ietekmēt arī pusaudža dzīves garums, kas, neskatoties uz salīdzinoši nelielo vecuma grupu intervālu, tomēr neḷauj izdarīt pilnīgi precīzus secinājumus par atšķirībām pašnāvnieciskās uzvedības izplatībā vecuma analizētajās vecuma grupās.

Darbā iegūtie rezultāti liecina, ka augstāka domu par pašnāvību izplatība vērojama arī to zēnu un meiteņu vidū, kuri savas ǵimenes materiālo stāvokli salīdzinot ar citām ǵimenēm Latvijā novērtējuši kā sliktāku, meitenēm šajā materiālā stāvokḷa vērtējuma kategorijā ir arī augstāka pašu ziņoto pašnāvības mēǵinājumu izplatība. Kopumā iegūtie rezultāti saskan ar ārvalstu pētījumos noskaidroto (Samm et al., 2010; Zubrick et al, 2016; Kokkevi et al., 2012), tomēr, vērtējot retrospektīvi, 2011. gadā, kad tika veikta anketēšana, Latvijas gimenes joprojām izjuta 2008.-2010. gada Latvijas finanšu un pārvaldes krīzes sekas. Šajā gadījumā, iespējams, par pētījuma priekšrocību uzskatāms fakts, ka tika izmantots pusaudža subjektīvais, nevis objektīvais ǵimenes materiālā stāvokḷa vērtējums, kas reprezentē arī sociālekonomisko situāciju saistīto person̄̄go pieredzi (Singh-Manoux, Adler and Marmot, 2003) un teorētiski rodas salīdzinot savas ǵimenes materiālo stāvokli ar citām ǵimenēm konkrētajā kopienā (dzīves vidē). N̦emot vērā daudzos ar materiālo stāvokli saistītos 
aspektus, būtu lietderīgi nākotnē analizēt arī to, cik cieša ir saistība starp pašnāvniecisko uzvedību un zemu ǵimenes materiālo stāvokli arī šobrīd vairākus gadus pēc Latvijas finanšu un pārvaldes krīzes.

Tāpat promocijas darbā noskaidrots, ka no respondentiem, kuri atzīmējuši pašnāvības mēgeinājumu dzīves laikā, 66,5\% atzīmējuši arī domas par pašnāvību, savukārt no respondentiem, kuri atzīmējuši domas par pašnāvību, 34,4\% atzīmējuši arī pašnāvības mēǵinājumu. 17 Eiropas valstīs veikta pētījuma par 15-16 gadus veciem pusaudžiem dati liecina, ka no respondentiem, kuri atzīmējuši pašnāvības mēgeinājumu dzīves laikā, 80,9\%93,9\% (atkarībā no valsts) atzīmējuši arī domas par paškaitējumu, savukārt no respondentiem, kuri atzīmējuši domas par paškaitējumu, vidēji trešadaḷa atzīmējuši arī pašnāvības mēginājumu (Kokkevi et al., 2012). Iepriekš minētajā pētījumā gan analizētas domas par paškaitējumu, taču iegūtie rezultāti vedina domāt, ka daḷa pašnāvības mēginājumi pusaudžu vidū notiek arī spontāni, vai mirkḷa iespaidā, bez ilgstošas nodoma apsvēršanas.

\subsection{Pašnāvnieciskā uzvedība un ar ğimenes vidi saistītie faktori}

Promocijas darbā iegūtie rezultāti liecina, ka nedzīvošana ar abiem biologiskajiem vecākiem palielina gan domu par pašnāvību, gan pašnāvības mēǵinājuma izredzes. Līdzīgi rezultāti iegūti arī citos pētījumos (Zaborskis, Sirvyte and Zemaitiene, 2016; Laukkanen et al., 2009; Nock et al., 2013; Kokkevi et al., 2012; Kokkevi et al., 2011; Morey et al., 2008; Wagner, Cole and Schwartzman, 1995; Ponnet et al., 2005). Tikai meitenēm pēc samērošanas ar vecumu, ǵimenes materiālo stāvokli un citiem pētītajiem ar ǵimenes vidi saistītajiem faktoriem saistība ar domām par pašnāvību nebija statistiski nozīmīga. Pētījumos noskaidrots, ka sakarības ciešumu ietekmē vecāku-bērnu attiecību kvalitāte, finansiālā situācija gimenēs, kur bērnu audzina viens no vecākiem, un saņemtās mīlestības apjoms gimenē, kam var būt būtiskāka loma 
par gimenes struktūru (Susukida, Wilcox and Mendelson, 2016; Turunen, 2013), tomēr fakts, ka promocijas darbā samērošana ar ǵimenes materiālo stāvokli saistību ar pašnāvniecisko uzvedību abās dzimumu grupās ietekmēja nebūtiski un pēc samērošanas ar citiem pētītajiem ar ğimenes vidi saistītajiem faktoriem (t.sk. vecāku emocionālo atbalstu) saistība vairs nebija statistiski nozīmīga tikai meitenēm attiecībā uz domām par pašnāvību liecina, ka pastāv vēl vairāki citi padziḷinātas izpētes vērti “mehānismi”, kas pusaudžus, kuri nedzīvo ar abiem biologiskajiem vecākiem, pakḷauj augstākam pašnāvnieciskās uzvedības riskam, piemēram, drošības un piederības sajūtas trūkums, kas var veicināt riska uzvedību (Brooks et al., 2012). Iegūtie rezultāti aktualizē politikas līmeņa risinājumu nepieciešamību, kas nodrošina finansiāla un cita veida atbalstu gimenēm, lai vecāki neizceḷotu no valsts, piemēram, finansiālu apsvērumu vadīti.

Iegūtie rezultāti liecina, ka abu pētīto pašnāvnieciskās uzvedības veidu izredzes abos dzimumos palielina arī vecāku emocionālā atbalsta trūkums, turklāt izredzes pašnāvnieciskajai uzvedībai ir augstākas gan pusaudžiem, kuri vecāku emocionālo atbalstu saņem reti/nekad, gan tiem, kuri šo atbalstu saņem tikai dažreiz (izņemot kategorijas "dažreiz” saistību ar pašnāvības mēǵinājumu zēniem). Turklāt šī saistība ar abiem pētītajiem pašnāvnieciskās uzvedības veidiem saglabājas statistiski nozīmīga arī pēc samērošanas ar vecumu, ǵimenes materiālo stāvokli un citiem pētītajiem ar ǵimenes vidi saistītajiem faktoriem. Iegūtie dati ḷauj secināt, ka “īstajā brīdī” pieejamam vecāku emocionālajam atbalstam var būt nozīmīga loma pašnāvnieciskās uzvedības profilaksē un šī atbalsta piln̄̄gai nepieejamībai iespējamas būtiskas negatīvas sekas. Līdzīgi rezultāti iegūti arī citās valstīs veiktos pētījumos (Zaborskis, Sirvyte and Zemaitiene, 2016; Mark et al., 2013; Brunner et al., 2014). Iegūtie rezultāti liecina, ka papildus vecāku lomas un izpratnes veicināšanai par emocionālā atbalsta sniegšanas nozīmi bērnam, nozīmīga loma ir arī citu 
atbalsta sistēmu (savstarpēji atbalstošas attiecības vienaudžu vidū, psihologu un pedagogu atbalsts skolā, krīzes un uzticības tālruṇi u.c.) stiprināšanai gadījumos, kad vecāku emocionālais atbalsts pusaudzim nav pieejams.

Abās dzimumu grupās gan domu par pašnāvību, gan pašnāvības mēǵinājuma izredzes ir augstākas pusaudžiem ar pašnāvniecisku pieredzi ǵimenē, jeb no ǵimenēm, kurās kāds no gímenes locekḷliem ir izdarījis pašnāvību un/vai pašnāvības mēǵinājumu. Turklāt š̄i faktora efekts uz pašnāvnieciskās uzvedības izredzēm ir ievērojams. Pašnāvnieciskas pieredzes gimenē saistība ar pašnāvniecisku uzvedību iezīmējas arī vairākos citos pêtījumos (Tomori et al., 2001; Portzky, De Wilde and van Heeringen, 2008; Nanayakkara et al., 2013; Brent and Mann, 2006; Chan et al., 2018; Cerel and Roberts, 2005). Novērotās saistības skaidrojums varētu būt balstīts Sociālās mācīšanās teorijā (angl. - Social Learning Theory), kurā uzsvērts, ka jauni uzvedības veidi tiek iegūti (apgūti) caur tiešu pieredzi vai novērojot citu rīcību (Bandura, 1971) - šāda hipotēze izteikta arī citā pētījumā (Chan et al., 2018). Pēdējos gados daḷa iepriekš minētās sakarības zinātniskajā literatūrā tiek skaidrota arī ar g̊enētiskajiem faktoriem, kas var "pārnest" suicidalitāti gan tiešā veidā, gan caur impulsīvi agresīvu uzvedību un garastāvokḷa traucējumiem, kas attiecīgi var provocēt pašnāvniecisku uzvedību (Turecki and Brent, 2016). Neskatoties uz saistības skaidrojumiem, iegūtie dati liecina, ka pusaudži ar pašnāvniecisku pieredzi gimenē ir nozīmīga riska grupa pašnāvnieciskai uzvedībai ar attiecīgi augstāku risku arī pabeigtai pašnāvībai, kas jāṇem vērā profilakses programmās, kā arī veidojot skrīninga "instrumentus", kas diferencē pusaudžus paaugstināta riska grupās tālākai intervencei.

Promocijas darbā iegūtie rezultāti liecina, ka pašnāvnieciskās uzvedības izredzes abās dzimumu grupās palielina arī fiziska vardarbība ğimenē un saistība saglabājas statistiski nozīmīga arī pēc samērošanas ar vecumu, ğimenes materiālo stāvokli un citiem pētītajiem ar gimenes vidi saistītajiem faktoriem 
par spīti faktam, ka apstiprinošā atbilde uz apgalvojumu "Tiku iesaistîts fiziskā vardarbībā savās mājās, kurā bija iesaistīts arī kāds pieaugušais" neḷauj pilnīgi precīzi noteikt šīs iesaistes veidu, respektīvi, vai vardarbība bijusi vērsta pret pašu pusaudzi, vai arī, piemēram, pusaudzis bijis fiziskas vardarbības liecinieks. Atbilde drīzāk iezīmē faktu, ka pusaudzis nāk no gimenes vides, kurā fiziska vardarbība notiek, kas arī var saistīties ar risku pašnāvnieciskai uzvedībai. Pret pusaudzi īstenota fiziska vardarb̄̄ba iezīmējas kā pašnāvnieciskas uzvedības riska faktors arī citos pētījumos (Waldrop et al., 2007; Guo et al., 2018), taču sakarība ar fiziskās vardarbības liecinieka statusu vairākos pētījumos nav apstiprinājusies (Turner et al., 2012; Isohookana et al., 2013), kas liecina, ka precīzāka fiziskās vardarbības gadījuma definēšana ḷautu veikt precīzāku salīdzinājumu un izvairīties no interpretācijām.

Promocijas darbā kopumā abos dzimumos apstiprinājusies saistība arī starp pētītajiem pusaudžu pašnāvnieciskās uzvedības veidiem un seksuālu uzmākšanos gímenē. Saistībā ar seksuālu uzmākšanos gan iezīmējas nedaudz atšķirīga situācija, nekā ar citiem pētītajiem ar ǵimenes vidi saistītajiem faktoriem, proti, vadoties pēc nesamēroto izredžu aprēķina, zēniem seksuāla uzmākšanā ǵimenē saistīta pat ar 10,7 reizes lielākām izredzēm domām par pašnāvību un 16 reizes lielākām izredzēm pašnāvības mēgeinājumam. Pēc samērošanas ar respondentu vecumu un gimenes materiālo stāvokli izredžu attiecības izmainās minimāli, taču pēc samērošanas ar citiem pētītajiem ar ǵimenes vidi saistītajiem faktoriem, lai arī abos dzimumos izredzes pašnāvnieciskajai uzvedībai seksuālas uzmākšanās gadījumā ir augstākas, statistiski nozīmīgi augstākas tās ir tikai attiecībā uz pašnāvības mēǵinājumiem zēniem. Šis fakts varētu būt skaidrojams ar diviem apstākḷiem. Pirmkārt, anketā uzdotais jautājums neļauj spriest par šīs uzmākšanās gadījumu interpretāciju pusaudžu vidū, uzmākšanās biežumu, kā arī to vai tā ir rezultējusies ar, piemēram, vēl smagāku seksuālās vardarbības veidu - dzimumaktu, kas 
ierobežo iespēju spriest par saistību augsta pašnāvnieciskās uzvedības riska grupās. Otrkārt, seksuālu uzmākšanos aptaujas anketās ir atzīmējuši tikai 3,2\% $(\mathrm{n}=111)$ zēnu un 1,2\% $(\mathrm{n}=46)$ meiteņu, kas būtiski ierobežo statistisko jaudu sakarības noskaidrošanai, samērojot ar citiem pētītajiem ar ǵimenes vidi saistîtajiem faktoriem. N̦emot vērā izteikti augstās izredzes pašnāvnieciskajai uzvedībai seksuālās uzmākšanās gadījumā vienfaktora analīzē un pēc samērošanas ar respondenta vecumu un gimenes materiālo stāvokli, augstākas (lai arī ne statistiski nozīmīgi) izredzes pēc samērošanas ar citiem pētītajiem ar gimenes vidi saistītajiem faktoriem, kā arī vairākos pētījumos atklāto saistību starp seksuālu vardarbību un pašnāvniecisko uzvedību (Waldrop et al., 2017; Martin et al., 2004; Ishookana et al., 2013; Guo et al., 2018), pirms pētījumu veikšanas ar lielāku mērķa grupas izlasi nav iespējams izdarìt viennozīmīgu secinājumu, ka grupās, kur saistība nebija statistiski nozīmīga, seksuālas uzmākšanās gadījumā nepastāv augstāks risks pašnāvnieciskajai uzvedībai. Attiecīgi būtu rekomendējams nākotnē veikt padziḷinātu šīs sakarības izpēti, izmantojot lielāku sasniegto respondentu atlasi, kā arī izmantot precīzākas fiziskās un seksuālās vardarbības definīcijas detalizētākai sakarību izpētei, tajā pat laikā ievērojot pētījumu ètikas apsvērumus un nodrošinot psihologisko atbalstu, lai neradītu bērnam emocionālas ciešanas, atsaucot atmiņā vai apjaušot seksuālās vardarbības epizodes.

\subsection{Pašnāvnieciskā uzvedība un ar vienaudžu vidi saistītie faktori}

Vērtējot promocijas darba ietvaros iegūtos rezultātus attiecībā uz pusaudžu pašnāvnieciskās uzvedības saistību ar vienaudžu emocionālā atbalsta trūkumu, jāsecina, ka meitenēm, kuras vienaudžu emocionālo atbalstu saņem reti/nekad vai tikai dažreiz, vērojamas augstākas izredzes domām par pašnāvību gan pirms, gan pēc samērošanas ar citiem pētītajiem faktoriem, taču zēniem saistība ir statistiski nozīmīga tikai reti/nekad saņemta vienaudžu emocionālā 
atbalsta gadījumā un zaudē statistisko nozīmību pēc samērošanas ar citiem pētītajiem ar vienaudžu vidi saistītajiem faktoriem. Tāpat zēnu vidū ne pirms, ne pēc samērošanas ar citiem faktoriem netika novērota statistiski nozīmīga saistība starp pašnāvības mēǵinājumu un vienaudžu emocionālā atbalsta trūkumu, kamēr meitenēm, kuras vienaudžu emocionālo atbalstu saņem reti/nekad šñ saistîba apstiprinājās. Iegūtie rezultāti vedina domāt, ka analizētajā pusaudžu vecuma grupā vienaudžu emocionālā atbalsta trūkums izteiktākas negatīvas psihoemocionālās konsekvences rada tieši meitenēm. Tāpat salīdzinājumam jāuzsver fakts, pašnāvnieciskās uzvedības sakarības ar emocionālā atbalsta trūkumu ǵimenē bija izteiktākas un noturīgākas, kas savukārt vedina domāt, ka, neraugoties uz faktu, ka ar gimenes un vienaudžu vidi saistītie faktori tika analizēti atsevišķos regresijas modeḷos, emocionālā atbalsta trūkums no gimenes, iespējams, rada būtiskākas negatīvas psihoemocionālas konsekvences nekā emocionālā atbalsta trūkums no vienaudžiem.

Abās dzimumu grupās gan pusaudžu domu par pašnāvību, gan pašnāvības mēǵinājuma izredzes palielina pašnāvnieciska pieredze vienaudžu vidū, turklāt š̄ faktora efekts uz pašnāvnieciskās uzvedības izredzēm ir būtiskākais starp pētītajiem ar vienaudžu vidi saistītajiem faktoriem gan pirms, gan pēc samērošanas. Arī šajā gadījumā viens no saistības skaidrojumiem varētu būt balstīts Sociālās mācī̌sanās teorijāa (angl. - Social Learning Theory), kurā uzsvērts, ka jauni uzvedības veidi tiek iegūti (apgūti) caur tiešu pieredzi vai novērojot citu rīcību (Bandura, 1971). Tāpat, iespējams, pusaudži var būt tendēti iesaistīties dažādās pusaudžu grupās, kur pašnāvnieciskās uzvedības risks var būt augstāks (Briggs, Slater and Bowley, 2017). Nenoliedzami zaudējums (pabeigtas pašnāvības gadījumā) var radīt emocionālas ciešanas un ilgstošu nespēju samierināties ar notikušo, kas attiecīgi var saistīties ar paša pusaudža pašnāvniecisku uzvedību. Līdzīgi rezultāti par pašnāvnieciskas 
pieredzes vienaudžu vidū saistību ar pusaudža pašnāvniecisku uzvedību iegūti arī citos pētījumos (Bearman and Moody, 2004; Ho et al., 2000; Nanayakkara et al., 2013). Jāsecina, ka pusaudži ar pašnāvniecisku pieredzi vienaudžu vidū, tāpat kā pusaudži ar pašnāvniecisku pieredzi gimenē ir nozīmīga riska grupa pašnāvnieciskai uzvedībai ar attiecīgi augstāku risku arī pabeigtai pašnāvībai, kas jāṇem vērā profilakses programmās, kā arī veidojot skrīninga "instrumentus", kas diferencē pusaudžus paaugstināta riska grupās tālākai intervencei.

Promocijas darbā iegūtie rezultāti liecina, ka gan domu par pašnāvību, gan pašnāvības mēǵinājuma izredzes abās dzimumu grupās palielina vienaudžu ņirgāšanās skolā un šĩ saistība saglabājas statistiski nozīmīga un izteikta arī pēc samērošanas ar respondenta vecumu, gimenes materiālo stāvokli un citiem pētìtajiem ar vienaudžu vidi saistītajiem faktoriem. Faktora būtisko ietekmi iezīmē arī fakts, ka arī tiem skolēniem, kuri vienaudžu ņirgāšanos skolā piedzīvojuši tikai dažreiz, pēc samērošanas atkarībā no dzimuma vērojamas 1,5 - 1,6 reizes lielākas izredzes domām par pašnāvību un 1,7 reizes lielākas izredzes pašnāvības mēginājumam, salīdzinot ar respondentiem, kuri to nav piedzīvojuši. Šeit gan jāuzsver fakts, ka promocijas darbā izmantotais jautājums ņirgāšanās noteikšanai atspoguḷo tikai verbālas ņirgāšanās faktu un š̄is ņirgāšanās biežumu, bet nav iespējams noteikt vai pusaudzis ir bijis pakḷauts arī citiem ņirgāšanās konceptā ietvertajiem vardarbības veidiem (piemēram, fiziska aizskaršana, izslēgšana no vienaudžu grupas, ņirgāšanās interneta vidē), kā arī vai verbālā ņirgāšanās īstenota spēka nevienlīdzības apstākḷ̆os starp upuri un pāridarītāju/-iem, kas, iespējams, palielinātu š̄ faktora efektu uz pašnāvniecisko uzvedību (Olweus, 1994), tomēr ņemot vērā, ka nereti upuris vienlaikus var būt pakḷauts vairākiem ņirgāšanās veidiem (Wang et al., 2010), l̦oti iespējams, ka daḷa no upuriem, kas piedzīvo verbālu ņirgāšanos, piedzīvo arī citus ņirgāšanās veidus. Interesanti, ka pretēji promocijas darbā iegūtajiem rezultātiem, dažos 
citās valstīs veiktos pētījumos sakarība starp verbālu ņirgāšanos un pašnāvniecisku uzvedību neapstiprinājās (Brunstein Klomek et al., 2019; Bazilay et al., 2017), taču vairāku citu pētījumu rezultāti apstiprina arī Latvijas pusaudžu vidū novēroto saistību starp verbālu ņirgāšanos un pašnāvniecisku uzvedību (Ford et al., 2017; Alavi et al., 2017). Promocijas darbā iegūtie rezultāti attiecībā uz saistību starp ņirgāšanās upura statusu un pašnāvniecisku uzvedību kopā ar augsto ņirgāšanās izplatību Latvijas skolēnu vidū (WHO, 2016) aktualizē nepieciešamību pēc starpsektoru sadarbībā balstītas ņirgāšanās profilakses programmas Latvijas skolās, kura, vienlaikus ar psihoemocionālās labklājības veicināšanu skolēnu vidū kopumā, sniegtu ieguldījumu arī pašnāvnieciskās uzvedības un attiecīgi arī pašnāvību profilaksē.

\subsection{Pašnāvnieciskā uzvedība un individuālie faktori}

Promocijas darbā iegūtie rezultāti liecina, ka gan augsts, gan vidēji augsts depresijas simptomu līmenis būtiski palielina abu pētīto pašnāvnieciskās uzvedības veidu izredzes abās dzimumu grupās gan pirms, gan pēc samērošanas ar pusaudža vecumu, ǵimenes materiālo stāvokli un citiem pêtītajiem individuālajiem faktoriem. Depresijas saikne ar pabeigtām pašnāvībām un pašnāvniecisku uzvedību ir vairākkārt apstiprinājusies gan pieaugušo, gan pusaudžu populācijās veiktos pētījumos (Gustafsson and Jacobsson, 2000; Lesage et al., 1994; Hirokawa et al., 2012; Nock et al., 2013; Zubrick et al., 2017), taču mazāk ir pētījumu, kuros tiek analizēta saikne ar paaugstinātu depresijas simptomu līmeni, jo īpaši pusaudžu vidū, jo īpaši Latvijā. Šīs sakarības izpētes nozīme slēpjas faktā, ka pusaudžu skaits ar depresijas simptomiem, kuri nesasniedz klīniski nozīmīgas depresijas diagnostiskos kritērijus, ir augsts (Cuijpers et al., 2006) un, kā liecina promocijas darbā iegūtie rezultāti, arī šie pusaudži ir pašnāvnieciskās uzvedības riska grupa, pie tam 1,7 - 2,0 reizes augstākas izredzes pašnāvnieciskajai 
uzvedībai tika novērotas arī vidēji augsta depresijas simptomu līmeņa gadījumā. Promocijas darbā izmantotā CES-D skala tiek rekomendēta dažāda depresijas simptomu līmeņa noteikšanai arī pusaudžu populācijā (Stockings et al., 2015), taču šajā gadījumā kā viens no ierobežojumiem ir jāmin fakts, ka depresijas simptomu līmeņa noskaidrošanai uzdotie jautājumi tiek uzdoti par pēdējo septiṇu dienu periodu, bet pašnāvnieciskās uzvedības noskaidrošanai uzdotie jautājumi raksturo pašnāvnieciskās uzvedības mūža prevalenci. Neskatoties uz šo ierobežojumu - novērotā depresijas simptomu līmeņa saistība ar pašnāvniecisku uzvedību ir nozīmīga. L,oti iespējams - faktori, kas izraisa depresijas simptomus, iedarbojas uz pusaudzi ilgstošā laika periodā, tāpat ilgstošs var būt arī paaugstināts depresijas simptomu līmenis. Neskatoties uz iepriekš minēto - promocijas darbā iegūtie rezultāti liecina, ka depresijas simptomu līmeṇa noteikšana Latvijas 14-17 gadus veco pusaudžu vidū pašnāvnieciskās uzvedības riska identificēšanai ir nozīmīga un rekomendējama.

Promocijas darbā iegūtie rezultāti liecina, ka arī zems un vidēji zems pašcienas līmenis būtiski palielina abu pētīto pašnāvnieciskās uzvedības veidu izredzes abās dzimumu grupās gan pirms, gan pēc samērošanas ar pusaudža vecumu, ǵimenes materiālo stāvokli un citiem pētītajiem individuālajiem faktoriem. Pašcieņa nosaka indivīda pārliecību par savu piemērotību dzīvei un dzīves izvirzịtajām prasībām, ir pārliecība spējā domāt, pārvarēt dzīves izaicinājumus, pārliecība par tiesībām būt laimīgam, sajūta, ka esi novērtēts, uzmanības cien̄̄gs, ar tiesībām aizstāvēt savas vajadzības un vēlmes, kā arī baudīt savu centienu aug̣̦lus. Pašcien̦a ir cilvēka normālas un veselīgas attīstības neatṇemama sastāvdaḷa (Branden, 1990). Arī pēc samērošanas ar depresijas simptomu līmeni un citiem individuālajiem faktoriem Latvijas pusaudžu vidū sagalabājas statistiski nozīmīga saistība ne tikai starp pašnāvniecisko uzvedību un zemu pašcieņas līmeni, bet arī starp pašnāvniecisko uzvedību un vidēji zemu pašcieņas līmeni - dažos citos ārvalstīs veiktos pētījumos pēc samērošanas ar 
depresiju statistiski nozīmīga saistība saglabājās tikai ar atsevišķiem kopējo pusaudža pašcieņu veidojošajiem elementiem vai atsevišķā dzimumu grupā (Wang et al., 2003; Wild, Flisher and Lombard, 2004), taču kopumā atklātā saistība ir saskaṇā ar citos, ārvalstīs veiktos pētījumos atklāto (Overholser et al., 1995; Lakey et al., 2014; O'Connor, Rasmussen and Hawton, 2009; Bridge, Goldstein and Brent, 2006; Tatnell et al., 2014). Promocijas darbā iegūtie rezultāti liecina, ka pašnāvības profilakses programmās būtiska loma ir arī intervencēm, kuras vērstas uz pusaudža pašcieņas līmeņa vairošanu (celšanu). Šādu intervenču izstrādāšana, aprobēšana un īstenošana varētu būt kompleksa un daudzu speciālistu sadarbībā balstīta, tomēr ir skaidrs, ka tā vairotu pusaudžu psihoemocionālo labklājību, spēju pārvarēt psihoemocionālos izaicinājumus un mazināt pašnāvniecisko uzvedību, kalpojot arī par nozīmīgu elementu arī pabeigtu pašnāvību profilaksei.

Vērtējot promocijas darba ietvaros iegūtos rezultātus attiecībā uz pusaudžu pašnāvnieciskās uzvedības saistību ar veselības pašvērtējumu jeb apmierinātību ar veselības stāvokli, jāsecina, ka meitenēm, kuras ar savu veselības stāvokli ir neapmierinātas vai ir vidēji apmierinātas, vērojamas augstākas izredzes domām par pašnāvību gan pirms, gan pēc samērošanas ar citiem pētītajiem individuālajiem faktoriem, taču zēniem pēc samērošanas ar citiem pētītajiem individuālajiem faktoriem saistība statistisko nozīmību zaudēja. Līdzīgi rezultāti attiecībā uz saistību ar domām par pašnāvību dzimumu grupās iegūti arī ASV veiktā pētījumā (Nkansah-Amankra, Walker, and Clark, 2009), kura diskusijas dạ̦ā minēts, ka meitenes savu veselību vērtē kā sliktāku arī pēc samērošanas ar dzīvesveidu raksturojošajiem un psihologiskajiem main̄̄gajiem (Vingilis, Wade and Seeley, 2002), kas vedina domāt, ka, iespējams, meitenes izteiktāk reaǵē uz savām veselības problēmām un vērtē tās kritiskāk nekā zēni. Tomēr Latvijas pusaudžu vidū abās dzimumu grupās apstiprinājās saistība starp neapmierinātību ar veselības stāvokli un 
pašnāvības mēǵinājumiem gan pirms, gan pēc samērošanas ar citiem pētītajiem individuālajiem faktoriem, kas liecina, ka attiecībā uz neapmierinātību ar veselības stāvokli un pašnāvības mēgeinājumiem riska grupā ir gan zēni, gan meitenes. Kopumā saistība starp sliktu veselības pašvērtējumu un pašnāvniecisku uzvedību apstiprinājusies arī Dienvidkorejā veiktā pētījumā (Kang et al., 2015), bet Peru veiktā pētījumā pēc samērošanas saistība vairs nav bijusi statistiski nozīmīga (Sharma et al., 2015).

Analizējot promocijas darba ietvaros iegūtos rezultātus attiecībā uz pusaudžu pašnāvnieciskās uzvedības saistību ar riskantu alkohola lietošanu jeb piedzeršanos dzīves laikāa jāsecina, ka meitenēm, kuras dzīves laikā piedzērušās 3 un vairāk reizes vai 1-2 reizes, vērojamas augstākas izredzes abiem pētītajiem pašnāvnieciskās uzvedības vediem gan pirms, gan pēc samērošanas ar citiem pētītajiem individuālajiem faktoriem, taču zēniem pēc samērošanas ar citiem pētītajiem individuālajiem faktoriem saistība starp pašnāvniecisko uzvedību un abām riskantas alkohola lietošanas kategorijām vairs nebija statistiski nozīmīga, turklāt zēniem saistība ar zemāko riskantas alkohola lietošanas kategoriju nebija statistiski nozīmīga jau vienfaktora analīzē. Pētījumos noskaidrots, ka pusaudžiem ar atkarību izraisošo vielu lietošanas problēmām bieži vērojami ar negatīvo stresu saistīti notikumi dzīvē, problēmas starppersonu attiecībās, reducēts sociālais atbalsts, vientulība un bezpalīdzības sajūta (Pompili et al., 2012) kā arī depresija (Bond et al., 2005). N̦emot vērā, ka promocijas darbā veikta faktora samērošana arī ar depresijas simptomu līmeni un pašcieņas līmeni, iespējams, zēniem tieši šie divi faktori vairāk skaidro saistību, kas iezīmējas nesamērotajos izredžu attiecību rādītājos, bet meitenēm, iespējams, sakarību ietekmē citi "mehānismi”. Literatūrā aprakstītas vairākas riskantas alkohola lietošanas motivācijas pusaudžiem hedoniskā motivācija, kad alkohols tiek lietots, lai radītu labu noskaņojumu, konformistiskā motivācija, kad alkohols tiek lietots, lai izvairītos no sociālā 
atraidījuma, socializācijas motivācija, kas raksturo alkohola lietošanu, lai iekḷautos grupā un problēmrisinošā motivācija, kas saistîta ar alkohola lietošanu, lai mazinātu nepatīkamas emocijas un izjūtas, un pašnāvnieciskā uzvedība visciešāk saistās tieši ar problēmrisinošo alkohola lietošanas motivāciju (Kokroḷeva u. c., 2008). Iespējams, atšķirības sakarībai ar pašnāvniecisko uzvedību dzimumu grupās saistītas ar atškirīibām riskantas alkohola lietošanas motivācijā dzimumu grupās, kas gan prasa padziḷinātu izpēti nākotnē. Kā priekšrocība riskantas alkohola lietošanas noteikšanai minama promocijas darba ietvaros izmantotā piedzeršanās definīcija, kas salīdzinoši precīzi ḷauj raksturot piedzeršanās faktu. Kopumā promocijas darba ietvaros iegūtie rezultāti par saistību ar pašnāvniecisko uzvedību saskan ar vairākumā ārvalstu pētījumu noskaidroto (Wu et al., 2004; Kokkevi et al., 2012; Peltzer and Pengpid, 2015; Wang and Yen, 2017), taču vairākumā šo pētījumu nav analizēta riskanta alkohola lietošana, bet gan alkohola lietošanas biežums.

Promocijas darbā iegūtie rezultāti liecina, ka pašnāvnieciskās uzvedības izredzes abās dzimumu grupās palielina arī ikdienas smēķēšana un saistība saglabājas statistiski nozīmīga arī pēc samērošanas ar vecumu, ǵimenes materiālo stāvokli un citiem pētītajiem individuālajiem faktoriem. Saistība starp pašnāvniecisku uzvedību un regulāru smēķēšanu ir apstiprinājusies arī daudzos citos pētījumos gan pieaugušo, gan pusaudžu populācijās (Poorolajal and Darvishi, 2016; Wu et al., 2004; Kokkevi et al., 2012), taču zinātnieku vidū joprojām nav pilnīgas skaidrības par šīs saistības cēloṇiem - apjomīgas metaanalīzes diskusijas daḷā norādīts, ka joprojām nav skaidrs vai smēḳēšana ietekmē pašnāvniecisku uzvedību caur bioloǵiskiem mehānismiem, kas saistās ar pašu smēḳēšanu, vai arī š̄i saistība skaidrojama ar kolinearitāti starp smēķēšanu un citiem faktoriem, kas ir saistīti ar pašnāvniecisko uzvedību, piemēram, psihosociāliem riska faktoriem vai dažādu cita veida riska uzvedību. 
Tāpat minēts, ka smēķēšana mēdz būt daḷa no problemātiskas uzvedības, kas ir saistîta ar dažādiem psihiskiem traucējumiem, narkotiku un alkohola lietošanu un seksuālu, un fizisku vardarbību, kas tiek uzskatīti par vieniem no nozīmīgākajiem pašnāvību un pašnāvnieciskas uzvedības cēloṇiem (Poorolajal and Darvishi, 2016). Šajā gadījumā gan kā promocijas darba priekšrocība minams fakts, ka ikdienas smēḳēšana loǵistiskās regresijas modelī tika samērota gan ar depresijas simptomu līmeni, gan pašcieņas līmeni, gan riskantu alkohola lietošanu, gan narkotiku lietošanu un, lai arī pēc samērošanas izredzes pašnāvnieciskai uzved̄̄bai samazinājās, saistība joprojām bija statistiski nozīmīga.

Iegūtie rezultāti liecina, ka pašnāvnieciskās uzvedības izredzes palielina arī narkotiku (marihuānas/hašiša, amfetamīna, LSD/citu halucinogēnu, kreka, kokaīna, heroīna, ekstazī vai spice) lietošana dzīves laikā. Attiecībā uz domām par pašnāvību saistība ar narkotiku lietošanu gan pirms, gan pēc samērošanas ir statistiski nozīmīga abās dzimumu grupās, bet attiecībā uz pašnāvības mēǵinājumu meitenēm pēc samērošanas ar citiem individuālajiem faktoriem šî saistība statistisko nozīmību zaudē. Arī šīs saistības skaidrojumi zinātniskajā literatūrā ir dažādi, piemēram, Taivānā veikta pētījuma par pusaudžu vielu lietošanas saistību ar pašnāvniecisku uzvedību dzimumu grupās diskusijas daḷā norādīts, ka akūta narkotiku intoksikācija var ietekmēt pusaudža spriestspēju un reducēt spēju kontrolēt impulsivitāti, savukārt hroniska - negatīvi ietekmēt smadzeņu attīstību un izmainīt uzvedību un procesus, kas regulē agresiju un impulsivitāti (Wang and Yen, 2017). Kopumā atklātā saistība starp narkotiku lietošanu un pašnāvniecisku uzvedību ir saskaṇā ar citos pētījumos noskaidroto (Wang and Yen, 2017; Kokkevi et al., 2012; Wu et al., 2004), kas liecina, ka arī narkotiku lietošana ir viens no faktoriem, kas diferencē pusaudžus ar augstāku pašnāvnieciskās uzvedības riskus, ko ir jāṇem vērā pašnāvnieciskās uzvedības un pašnāvību profilakses intervenču plānošanā un īstenošanā. 


\subsection{Citi apsvērumi}

N̦emot vērā iepriekš minētos faktus jāsecina, ka pirmā promocijas darba hipotēze, ka abās dzimumu grupās pastāv saistība starp pusaudžu pašu ziņotajām domām par pašnāvību un visiem pētītajiem ar ǵimenes vidi saistītajiem, vienaudžu vidi raksturojošajiem un individuālajiem faktoriem ir apstiprinājusies daḹèji.

Arī otrā promocijas darba hipotēze, ka abās dzimumu grupās pastāv saistība starp pusaudžu pašu ziņotajiem pašnāvības mēginājumiem un visiem pētītajiem ar ǵimenes vidi saistītajiem, vienaudžu raksturojošajiem un individuālajiem faktoriem ir apstiprinājusies daḷēji.

Papildus jāṇem vērā fakts, ka pētījuma šķērsgriezuma dizains neḷauj izdarīt secinājumus par cēloṇu-seku sakarībām laikā. Tāpat pētījuma rezultātus var ietekmēt sistemātiskā atcerēšanās kḷūda, jo īpaši attiecībā uz main̄̄gajiem, kas aprēķināti pēc pusaudžu atbildēm par visas dzīves laiku, līdz ar to atcerēšanās novirze var ietekmēt saistības ciešumu starp pašnāvniecisku uzvedību un pētitajiem faktoriem.

N̦emot vērā dažādus apstākḷus, t. sk. skolēnu kavējumus un atteikumus piedalīties aptaujā, aprēķinātais nerespondences līmenis skolās un klasēs, kas piekrita piedalīties aptaujā bija 15,3\% no visiem skolēniem (Trapencieris u. c., 2012). N̦emot vērā, ka, iespējams, pašnāvnieciskās uzvedības un dažāda veida riska faktoru izplatība šajās pusaudžu grupās var atšķirties, pilnīgas informācijas iegūšanai nākotnē būtu nepieciešams veikt papildus pētījumus par pašnāvnieciskās uzvedības izplatību un asociētajiem riska faktoriem skolu kavējošo, kā arī skolu neapmeklējošo pusaudžu vidū.

Promocijas darba ietvaros veiktā analīze ir vienīgā līdz šim veiktā šada veida un detalizācijas pakāpes attiecīgajai pusaudžu vecuma grupai reprezentatīva ar pusaudžu pašnāvniecisko uzvedību saistīto faktoru analīze Latvijā ar ne tikai teorētisku, bet arī būtisku praktisku ieguldījumu riska grupu 
diferencēšanai un sabiedrības veselības politikas veidošanai un intervenču īstenošanai pašnāvnieciskās uzvedības un pašnāvību profilaksei. 


\section{SECINĀJUMI}

1. Ievērojams īpatsvars - $15,7 \%$ Latvijas $14-17$ gadus veco pusaudžu pārdomājuši konkrētu veidu, vietu vai rīcību pašnāvības izdarīšanai nedaudz vairāk kā katrs desmitais zēns $(11,7 \%)$ un gandrīz katra piektā meitene $(19,4 \%)$.

2. Ievērojams īpatsvars $-8,2 \%$ Latvijas $14-17$ gadus veco pusaudžu atzīmē dzīves laikā izdarītu pašnāvības mēǵinājumu - 5,9\% zēnu un 10,2\% meitenu.

3. Abu pētīto pašnāvnieciskās uzvedības veidu izplatība ir augstāka meiteņu vidū.

4. Domu par pašnāvību izplatība ir augstāka to pusaudžu vidū, kuri savas gímenes materiālo stāvokli salīdzinājumā ar citām ǵimenēm Latvijā vērtē kā sliktāku, savukārt meiteņu vidū šādi vērtēta gimenes materiālā stāvokḷa gadījumā vērojama arī augstāka pašnāvības mēǵinājumu izplatība.

5. Ar ǵimenes vidi saistītie faktori, kas neatkarīgi paaugstina izredzes domām par pašnāvību abās dzimumu grupās ir pašnāvnieciska pieredze gimenē, fiziska vardarbība gimenē, reti/nekad un dažreiz izjusts vecāku emocionālais atbalsts, bet atsevišķi zēniem - nedzīvošana ar abiem biolog̣iskajiem vecākiem.

6. Ar ǵimenes vidi saistītie faktori, kas neatkarīgi paaugstina izredzes pašnāvības mēǵinājumam abās dzimumu grupās ir pašnāvnieciska pieredze gimenē, fiziska vardarbība ğimenē, reti/nekad izjusts vecāku emocionālais atbalsts un nedzīvošana ar abiem bioloǵiskajiem vecākiem, bet atsevišḳi zēniem - seksuāla uzmākšanās ǵimenē un atsevišḳi meitenēm - dažreiz izjusts vecāku emocionālais atbalsts.

7. Ar vienaudžu vidi saistītie faktori, kas neatkarīgi paaugstina izredzes domām par pašnāvību abās dzimumu grupās ir pašnāvnieciska pieredze 
vienaudžu vidū, vienmēr/bieži un dažreiz piedzīvota ņirgāšanās skolā, bet atsevišḳi meitenēm - reti/nekad un dažreiz izjusts vienaudžu emocionālais atbalsts.

8. Ar vienaudžu vidi saistītie faktori, kas neatkarīgi paaugstina izredzes pašnāvības mēǵinājumam abās dzimumu grupās ir pašnāvnieciska pieredze vienaudžu vidū, vienmēr/bieži un dažreiz piedzīvota ņirgāšanās skolā, bet atsevišķi meitenēm - reti/nekad izjusts vienaudžu emocionālais atbalsts.

9. Individuālie faktori, kas neatkarīgi paaugstina izredzes domām par pašnāvību abās dzimumu grupās ir augsts un vidēji augsts depresijas simptomu līmenis, zems un vidēji zems pašcieņas līmenis, narkotiku lietošana dzīves laikā un ikdienas smēkēšana, bet atsevišķi meitenēm neapmierinātība un vidēja apmierinātība ar savu veselības stāvokli, kā arī riskanta alkohola lietošana dzīves laikā.

10. Individuālie faktori, kas neatkarīgi paaugstina izredzes pašnāvības mēǵinājumam abās dzimumu grupās ir augsts un vidēji augsts depresijas simptomu līmenis, zems un vidēji zems pašcieņas līmenis, ikdienas smēḳēšana un neapmierinātība ar savu veselības stāvokli, atsevišķi meitenēm - riskanta alkohola lietošana dzīves laikā, bet atsevišḳi zēniem - narkotiku lietošana dzīves laikā. 


\section{PRAKTISKĀS REKOMENDĀCIJAS}

1. Promocijas darba secinājumi liecina, ka pastāv nozīmīga saikne starp pusaudžu pašnāvniecisko uzvedību un gan ar ǵimenes vidi saistītajiem, gan vienaudžu vidi raksturojošajiem, gan individuālajiem faktoriem un šīs ietekmējošo faktoru grupas, un atsevišķus faktorus jāṇem vērā gan speciālistiem, kuri strādā ar pusaudžiem ikdienā (g̊imenes ārsti, psihologi, psihoterapeiti, psihiatri, pedagogi, sociālie pedagogi u.c.) potenciāla riska identificēšanai, gan sabiedrības veselības, labklājības un citu iesaistīto sektoru politikas veidotājiem intervenču plānošanai sekmīgai pašnāvnieciskās uzvedības un pašnāvību profilaksei, uzman̄ibu veltot gan psihologíiski atbalstošas un no vardarbības brīvas gimenes un vienaudžu vides veidošanai, gan pusaudžu pašcieņas vairošanai, depresijas mazināšanai un profilaksei, vispārējās veselības veicināšanai un atkarību izraisošo vielu lietošanas profilaksei.

2. Latvijā, līdzīgi kā citās ES valstīs, nepieciešams izstrādāt un apstiprināt atsevišķas, specifiskas sabiedrības psihiskās veselības veicināšanas un pašnāvību profilakses pamatnostādnes ar konkrētām aktivitātēm pusaudžu pašnāvnieciskās uzvedības un pašnāvību profilaksei. Problēmas aktualitāte augsto pašnāvību rādītāju kontekstā Latvijā Sabiedrības veselības veselības pamatnostādnēs ir uzsvērta jau šobrīd un promocijas darba secinājumi sniedz uz pierādījumiem balstītu informāciju starpsektoru (veselības, labklājības, izglītības u.c.) sadarbībā balstîtu profilakses intervenču īstenošanai pusaudžu populācijā kopumā un riska grupās.

3. Balstoties uz promocijas darbā iegūtajiem rezultātiem valsts līmeṇa ekspertu grupās iespējams lemt par pašnāvnieciskās uzvedības izplatības noteikšanai izmantoto jautājumu kā indikatoru nepārtrauktu iekḷaušanu 
periodiskajos reprezentatīvajos pusaudžu populācijas apsekojumos, lai varētu sekot situācijas izmaiṇām dinamikā un atbilstoši reaǵèt.

4. Nepieciešams turpināt izpēti, īpašu uzmanību pievēršot detalizētai, padziḷinātai un papildus saistību izpētei starp pašnāvniecisko uzvedību un dažāda veida gimenē un vienaudžu vidū īstenotu vardarbību (fizisku, seksuālu, emocionālu, fizisku atstāšanu novārtā, emocionālu atstāšanu novārtā, ņirgāšanos, izslēdzot no vienaudžu grupas, ņirgāšanos interneta vidē u.c.) pēc iespējas lielās respondentu atlases kopās ar atbilstošu statistisko jaudu precīzai saistību noskaidrošanai ar faktoriem, kuru izplatība ir salīdzinoši zema (jo īpaši, seksuālu vardarbību).

5. Tāpat būtisku papildus ieguldījumu sniegtu pašnāvnieciskās uzvedības izpēte starp pusaudžiem ar dažāda veida riskantas alkohola lietošanas motivāciju, starp ikdienas smēķēšanu un pašnāvniecisko uzvedību atklātās saistības cēloṇu izpēte, sakarību izpēte ar elektronisko smēķěšanas ierīču lietošanu un procesu atkarībām, kā arī pašnāvnieciskās uzvedības izplatības un ar to saistīto faktoru analīze skolu kavējošo pusaudžu vidū. 


\section{IZMANTOTĀ LITERATŪRA}

1. Alavi, N., Reshetukha, T., Prost, E., Antoniak, K., Patel, C., Sajid, S., Groll, D. 2017. Relationship between Bullying and Suicidal Behaviour in Youth presenting to the Emergency Department. Journal of the Canadian Academy of Child and Adolescent Psychiatry. 26(2), 70-77.

2. Bandura, A. 1971. Social Learning Theory. New York (NY): General Learning Corporation.

3. Barzilay, S., Brunstein Klomek, A., Apter, A., Carli, V., Wasserman, C., Hadlaczky, G., Hoven, C. W., Sarchiapone, M., Balazs, J., Kereszteny, A., Brunner, R., Kaess, M., Bobes, J., Saiz, P., Cosman, D., Haring, C., Banzer, R., Corcoran, P., Kahn, J.P., Postuvan, V., Podlogar, T., Sisask, M., Varnik, A., Wasserman, D. 2017. Bullying Victimization and Suicide Ideation and Behavior Among Adolescents in Europe: A 10-Country Study. The Journal of adolescent health. 61(2), 179-186.

4. Bearman, P. S., Moody, J. 2004. Suicide and friendships among American adolescents. American Journal Of Public Health. 94(1), 89-95.

5. Beautrais, A. L. 2002. Gender issues in youth suicidal behaviour. Emergency medicine (Fremantle, W.A.). 14(1), 35-42.

6. Bond, L., Toumbourou, J. W., Thomas, L., Catalano, R. F., Patton, G. 2005. Individual, family, school, and community risk and protective factors for depressive symptoms in adolescents: a comparison of risk profiles for substance use and depressive symptoms. Prevention science. 6(2), 73-88.

7. Branden, N. 1990. What Is Self-Esteem? In: International Conference on SelfEsteem. Asker/Oslo: International Conference on Self-Esteem. Available from: https://eric.ed.gov/?id=ED325783 [accessed on 11.09.2018].

8. Brent, D. A., Mann, J. J. 2006. Familial pathways to suicidal behavior-understanding and preventing suicide among adolescents. The New England journal of medicine. 355(26), 2719-2721.

9. Bridge, J. A., Goldstein, T. R., Brent, D. A. 2006. Adolescent suicide and suicidal behavior. Journal of child psychology and psychiatry, and allied disciplines. 47:3/4, 372-394.

10. Briggs, S., Slater, T., Bowley, J. 2017. Practitioners' experiences of adolescent suicidal behaviour in peer groups. Journal of psychiatric and mental health nursing. 24(5), 293-301.

11. Brooks, F. M., Magnusson, J., Spencer, N., Morgan, A. 2012. Adolescent multiple risk behaviour: an asset approach to the role of family, school and community. Journal of public health (Oxford, England). 34, i48-56. Available from: doi: 10.1093/pubmed/fds001 [accessed on 01.08.2018].

12. Brunner, R., Kaess, M., Parzer, P., Fischer, G., Carli, V., Hoven, C. W., Wasserman, C., Sarchiapone, M., Resch, F., Apter, A., Balazs, J., Barzilay, S., Bobes, J., Corcoran, P., Cosmanm, D., Haring, C., Iosuec, M., Kahn, J. P., Keeley, H., Meszaros, G., Nemes, B., Podlogar, T., Postuvan, V., Saiz, P. A., Sisask, M., Tubiana, A., Varnik, A., Wasserman, D. 2014. Life-time prevalence and psychosocial correlates of adolescent direct self-injurious behavior: a comparative 
study of findings in 11 European countries. Journal of child psychology and psychiatry, and allied disciplines. 55(4), 337-348.

13. Brunstein Klomek, A., Barzilay, S., Apter A., Carli, V., Hoven, C. W., Sarchiapone, M., Hadlaczky, G., Balazs, J., Kereszteny, A., Brunner, R., Kaess, M., Bobes, J., Saiz, P. A., Cosman, D., Haring, C., Banzer, R., McMahon, E., Keeley, H., Kahn, J. P., Postuvan, V., Podlogar, T., Sisask, M., Varnik, A., Wasserman, D. 2019. Bi-directional longitudinal associations between different types of bullying victimization, suicide ideation/attempts, and depression among a large sample of European adolescents. Journal of child psychology and psychiatry, and allied disciplines. 60(2), 209-215.

14. Cerel, J., Roberts, T. A. 2005. Suicidal behavior in the family and adolescent risk behavior. The Journal of adolescent health. 36(4), 352.e9-16.

15. Chan, S., Denny, S., Fleming, T., Fortune, S., Peiris-John, R., Dyson, B. 2018. Exposure to suicide behaviour and individual risk of self-harm: Findings from a nationally representative New Zealand high school survey. The Australian and New Zealand journal of psychiatry. 52(4), 349-356.

16. Colarossi, L. G., Eccles, J. S. 2003. Differential effects of support providers on adolescents' mental health. Social work research. 27(1), 19-30.

17. Cuijpers, P., van Straten, A., Smits, N., Smit, F. 2006. Screening and early psychological intervention for depression in schools: systematic review and metaanalysis. European child \& adolescent psychiatry. 15(5), 300-307.

18. De Leo, D., Burgis, S., Bertolote, J. M., Kerkhof, A. J., Bille-Brahe, U. 2006. Definitions of suicidal behavior: Lessons learned from the WHo/EURO multicentre Study. Crisis. 27(1), 4-15.

19. Eurostat. 2018. Suicide death rate by age group. In: Eurostat. Available from: https://ec.europa.eu/eurostat/web/products-datasets/-/tps00202 [accessed on 28.06.2018]

20. Field, A. 2013. Discovering statistics using IBM SPSS Statistics. 4th ed. Canada: SAGE Publications.

21. Ford, R., King, T., Priest, N., Kavanagh, A. 2017. Bullying and mental health and suicidal behaviour among 14- to 15-year-olds in a representative sample of Australian children. The Australian and New Zealand journal of psychiatry. 51(9), 897-908.

22. Goodfellow, B., Kõlves, K., De Leo, D. 2018. Contemporary Nomenclatures of Suicidal Behaviors: A Systematic Literature Review. Suicide \& life-threatening behavior. 48(3), 353-366.

23. Guo, L., Wang, W., Gao, X., Huang, G., Li, P., Lu, C. 2018. Associations of Childhood Maltreatment with Single and Multiple Suicide Attempts among Older Chinese Adolescents. The Journal of pediatrics. 196, 244-250. Available from: doi:10.1016/j.jpeds.2018.01.032 [accessed on 20.08.2018].

24. Gustafsson, L., Jacobsson, L. 2000. On mental disorder and somatic disease in suicide: A psychological autopsy study of 100 suicides in northern Sweden. Nordic Journal of Psychiatry. 54(6), 383-395.

25. Hibell, B., Guttormsson U., Ahlström, S., Balakireva, O., Bjarnason T., Kokkevi, A., Kraus, L. 2009. The 2007 ESPAD Report: Substance Use Among Students in 35 European Countries. Stockholm: The Swedish Council for Information on Alcohol and Other Drugs (CAN). 
26. Hinkle, D. E., Wiersma, W., Jurs, S. G. 2003. Applied Statistics for the Behavioral Sciences: $5^{\text {th }}$ ed. Boston: Houghton Mifflin.

27. Hirokawa, S., Kawakami, N., Matsumoto, T., Inagaki, A., Eguchi, N., Tsuchiya, M., Katsumata, Y., Akazawa, M., Kameyama, A., Tachimori, H., Takeshima, T. 2012. Mental disorders and suicide in Japan: a nation-wide psychological autopsy case-control study. Journal of affective disorders. 140(2), 168-175.

28. Ho, T. P., Leung, P. W., Hung, S. F., Lee, C. C., Tang, C. P. 2000. The mental health of the peers of suicide completers and attempters. Journal of child psychology and psychiatry, and allied disciplines. 41(3), 301-308.

29. Hu, J., Dong, Y., Chen, X., Liu, Y., Ma, D., Liu, X., Zheng, R., Mao, X., Chen, T., He, W. 2015. Prevalence of suicide attempts among Chinese adolescents: A metaanalysis of cross-sectional studies. Comprehensive psychiatry. 61, 78-89. Available from: doi:10.1016/j.comppsych.2015.05.001 [accessed on 16.07.2018].

30. Isohookana, R., Riala, K., Hakko, H., Räsänen, P. 2013. Adverse childhood experiences and suicidal behavior of adolescent psychiatric inpatients. European child \& adolescent psychiatry. 22(1), 13-22.

31. Joe, S., Baser, R. S, Neighbors, H. W., Caldwell, C. H., Jackson, J. S. 2009. 12month and lifetime prevalence of suicide attempts among black adolescents in the National Survey of American Life. Journal of the American Academy of Child and Adolescent Psychiatry. 48(3), 271-282.

32. Kang, E. H., Hyun, M. K., Choi, S. M., Kim, J. M., Kim, G. M., Woo, J. M. 2015. Twelve-month prevalence and predictors of self-reported suicidal ideation and suicide attempt among Korean adolescents in a web-based nationwide survey. The Australian And New Zealand Journal Of Psychiatry. 49 (1), 47-53.

33. Kerr, M., Stattin, H., Biesecker, G., Ferrer-Wreder, L. 2003. Relationships with parents and peers in adolescence. In: Developmental psychology. Vol. 6. Lerner, R., Easterbrooks, M.A., Mistry, J. New York (NY): John Wiley \& Sons Inc, 395419.

34. Kinchin, I., Doran, C. M. 2018. The Cost of Youth Suicide in Australia. International journal of environmental research and public health. 15(4), E672. Available from: doi:10.3390/ijerph15040672 [accessed on 09.07.2018].

35. Kokkevi, A., Rotsika, V., Arapaki, A., Richardson, C. 2011. Increasing selfreported suicide attempts by adolescents in Greece between 1984 and 2007. Social psychiatry and psychiatric epidemiology. 46(3), 231-237.

36. Kokkevi, A., Rotsika, V., Arapaki, A., Richardson, C. 2012. Adolescents' selfreported suicide attempts, self-harm thoughts and their correlates across 17 European countries. Journal of child psychology and psychiatry, and allied disciplines. 53(4), 381-389.

37. Koroḷeva, I., Mieriņa, I., Goldmanis, M., Sniķere, S., Trapencieris, M. 2008. ESPAD 2007: Atkarību izraisošo vielu lietošanas paradumi un tendences skolènu vidū. Rīga: Sabiedrības veselības aǵentūra.

38. Krug, E. G., Dahlberg, L. L., Mercy J. A., Zwi, A. B., Lozano R. 2002. World report on violence and health. Geneva: World Health Organization.

39. Lakey, C. E., Hirsch, J. K., Nelson, L. A., Nsamenang, S. A. 2014. Effects of contingent self-esteem on depressive symptoms and suicidal behavior. Death studies. 38(6-10), 563-570. 
40. Laukkanen, E., Rissanen, M. L., Honkalampi, K., Kylmä, J., Tolmunen, T., Hintikka, J. 2009. The prevalence of self-cutting and other self-harm among 13- to 18-year-old Finnish adolescents. Social psychiatry and psychiatric epidemiology. 44(1), 23-28.

41. Lenzi, M., Vieno, A., Perkins, D. D., Santinello, M., Pastor, M., Mazzardis, S. 2012. Perceived neighborhood social resources as determinants of prosocial behavior in early adolescence. American journal of community psychology. 50(12), 37-49.

42. Lesage, A. D., Boyer, R., Grunberg, F., Vanier, C., Morissette, R., MénardButeau, C., Loyer, M. 1994. Suicide and mental disorders: a case-control study of young men. The American journal of psychiatry. 151(7), 1063-1068.

43. LR Ministru kabinets. (2014). Sabiedrības veselības pamatnostādnes 2014.-2020. gadam: LR Ministru kabineta rīkojums Nr. 589, 14.10.2014.

44. Madge, N., Hawton, K., McMahon, E. M., Corcoran, P., De Leo, D., de Wilde, E. J., Fekete. S., van Heeringen, K., Ystgaard, M., Arensman, E. 2011. Psychological characteristics, stressful life events and deliberate self-harm: findings from the Child \& Adolescent Self-harm in Europe (CASE) Study. European child \& adolescent psychiatry. 20(10), 499-508.

45. Mark, L., Samm, A., Tooding, L. M., Sisask, M., Aasvee, K., Zaborskis, A., Zemaitiene, N., Värnik, A. 2013. Suicidal ideation, risk factors, and communication with parents. An HBSC study on school children in Estonia, Lithuania, and Luxembourg. Crisis. 34(1), 3-12.

46. Martin, G., Bergen, H. A., Richardson, A. S., Roeger, L., Allison, S. 2004. Sexual abuse and suicidality: gender differences in a large community sample of adolescents. Child abuse \& neglect. 28(5), 491-503.

47. Morey, C., Corcoran, P., Arensman, E., Perry, I. J. 2008. The prevalence of selfreported deliberate self harm in Irish adolescents. BMC public health. 8:79. Available from: doi:10.1186/1471-2458-8-79 [accessed on 30.08.2018].

48. Nanayakkara, S., Misch, D., Chang, L., Henry, D. 2013. Depression and exposure to suicide predict suicide attempt. Depression and anxiety. 30(10), 991-996.

49. Newcombe, R.G. 1998. Two-sided confidence intervals for the single proportion: comparison of seven methods. Statistics in medicine. 17(8), 857-872.

50. Nkansah-Amankra, S., Walker, A. D., Clark, A. 2009. Suicidal Behaviors, Self Rated Health and Multiple Health Risk Behaviors Among Adolescents: Exploring New Perspectives With High School Students in Suicide Prevention Research. Annals of Epidemiology. 19(9), 669-670.

51. Nock, M. K., Green, J. G., Hwang, I., McLaughlin, K. A., Sampson, N. A., Zaslavsky, A.M., Kessler, R.C. 2013. Prevalence, correlates, and treatment of lifetime suicidal behavior among adolescents: results from the National Comorbidity Survey Replication Adolescent Supplement. JAMA Psychiatry. 70(3), 300-10.

52. O'Connor, R. C., Rasmussen, S., Hawton, K. 2009. Predicting deliberate self-harm in adolescents: a six month prospective study. Suicide \& life-threatening behavior. 39(4), 364-875.

53. Olweus, D. 1994. Bullying at school: basic facts and effects of a school based intervention program. Journal of child psychology and psychiatry, and allied disciplines. 35(7), 1171-1190. 
54. Overholser, J. C., Adams, D. M., Lehnert, K. L., Brinkman, D. C. 1995. Selfesteem deficits and suicidal tendencies among adolescents. Journal of the American Academy of Child and Adolescent Psychiatry. 34(7), 919-928.

55. Peltzer, K., Pengpid, S. 2015. Early Substance Use Initiation and Suicide Ideation and Attempts among School-Aged Adolescents in Four Pacific Island Countries in Oceania. International journal of environmental research and public health. 12(10), 12291-12303.

56. Pompili, M., Serafini, G., Innamorati, M., Biondi, M., Siracusano, A., Di Giannantonio, M., Giupponi, G., Amore, M., Lester, D., Girardi, P., MöllerLeimkühler, A. M. 2012. Substance abuse and suicide risk among adolescents. European archives of psychiatry and clinical neuroscience. 262(6), 469-485

57. Ponnet, K., Vermeiren, R., Jespers, I., Mussche, B., Ruchkin, V., Schwab-Stone, M., Deboutte, D. 2005. Suicidal behaviour in adolescents: associations with parental marital status and perceived parent-adolescent relationship. Journal of affective disorders. 89(1-3), 107-113.

58. Poorolajal, J., Darvishi, N. 2016. Smoking and Suicide: A Meta-Analysis. PLoS One. 11(7), e0156348. Available from: doi:10.1371/journal.pone.0156348 [accessed on 03.09.2018]

59. Portzky, G., De Wilde, E., van Heeringen, K. 2008. Deliberate self-harm in young people: differences in prevalence and risk factors between the Netherlands and Belgium. European child \& adolescent psychiatry. 17(3), 179-186.

60. Radloff, L. S. 1977. The CES-D scale: A self-report depression scale for research in the general population. Applied Psychological Measurement. 1(3), 385-401.

61. Rhodes, A. E., Boyle, M. H., Bridge, J. A., Sinyor, M., Links, P. S., Tonmyr, L., Skinner, R., Bethell, J. M., Carlisle, C., Goodday, S., Hottes, T. S., Newton, A., Bennett, K., Sundar, P., Cheung, A. H., Szatmari, P. 2014. Antecedents and sex/gender differences in youth suicidal behavior. World journal of psychiatry. 4(4), 120-132.

62. Rosenberg, M. 1965. Society and The Adolescent Self-Image. Princeton: Princeton University Press.

63. Rothon, C., Goodwin, L., Stansfeld, S. 2012. Family social support, community "social capital" and adolescents' mental health and educational outcomes: a longitudinal study in England. Social psychiatry and psychiatric epidemiology. 47(5), 697-709.

64. Safer, D. J. 1997. Self-reported suicide attempts by adolescents. Annals of clinical psychiatry. 9(4), 263-269.

65. Samm, A., Tooding, L. M., Sisask, M., Kõlves, K., Aasvee, K., Värnik, A. 2010. Suicidal thoughts and depressive feelings amongst Estonian schoolchildren: effect of family relationship and family structure. European child \& adolescent psychiatry. 19(5), 457-68.

66. Sharma, B., Nam, E. W., Kim, H. Y., Kim, J. K. 2015. Factors Associated with Suicidal Ideation and Suicide Attempt among School-Going Urban Adolescents in Peru. International journal of environmental research and public health. 12(11), 14842-14856.

67. Šica, K., Pulmanis, T., Taube, M. 2017. Psihiskā veselība Latvijā 2016. gadā: tematiskais ziņojums. Rīga: Slimību profilakses un kontroles centrs. 
68. Singh-Manoux, A., Adler, N. E., Marmot, M. G. 2003. Subjective social status: its determinants and its association with measures of ill-health in the Whitehall II study. Social science \& medicine. 56(6), 1321-1333.

69. Skrule, J. 2014. Priekšlaicīgas mirstības analīze. Potenciāli zaudētie mūža gadi Latvijā 2013. gadā. Rīga: Slimību profilakses un kontroles centrs.

70. Sniķere, S., Trapencieris, M. 2016. ESPAD 2015: Atkarību izraisošo vielu lietošanas paradumi un tendences skolēnu vidū. Rīga: Slimību profilakses un kontroles centrs.

71. Stadler, C., Feifel, J., Rohrmann, S., Vermeiren, R., Poustka, F. 2010. Peervictimization and mental health problems in adolescents: are parental and school support protective? Child psychiatry and human development. 41(4), 371-386.

72. Štāle, M., Treide, A., Rožkalne, G. 2016. Neinfekciju slimības - saslimstība, mirstība, riska faktori: situācija Latvijā 2006.-2015. gadā. Rīga: Slimību profilakses un kontroles centrs.

73. Stockings, E., Degenhardt, L., Lee, Y. Y., Mihalopoulos, C., Liu, A., Hobbs, M., Patton, G. 2015. Symptom screening scales for detecting major depressive disorder in children and adolescents: a systematic review and meta-analysis of reliability, validity and diagnostic utility. Journal of affective disorders. 174, 447463. Available from: doi: 10.1016/j.jad.2014.11.061 [accessed on 01.08.2018]

74. Susukida, R., Wilcox, H. C., Mendelson, T. 2016. The association of lifetime suicidal ideation with perceived parental love and family structure in childhood in a nationally representative adult sample. Psychiatry research. 237, 246-51. Available from: doi:10.1016/j.psychres.2016.01.033 [accessed on 01.08.2018].

75. Sweeting, H., Hunt, K. 2014. Adolescent socio-economic and school-based social status, health and well-being. Social science \& medicine. 121, 39-47. Available from: doi:10.1016/j.socscimed.2014.09.037 [accessed on 01.08.2018].

76. Tatnell, R., Kelada, L., Hasking, P., Martin, G. 2014. Longitudinal analysis of adolescent NSSI: the role of intrapersonal and interpersonal factors. Journal of abnormal child psychology. 42(6), 885-896.

77. Tomori, M., Kienhorst, C. W., de Wilde, E. J., van den Bout, J. 2001. Suicidal behaviour and family factors among Dutch and Slovenian high school students: a comparison. Acta psychiatrica Scandinavica. 104(3), 198-203.

78. Trapencieris, M., Sniķere, S., Koroḷeva, I., Kārkliṇa, I. 2012. ESPAD 2011: Atkarību izraisošo vielu lietošanas paradumi un tendences skolēnu vidū. Rīga: Slimību profilakses un kontroles centrs.

79. Tsirigotis, K., Gruszczynski, W., Tsirigotis, M. 2011. Gender differentiation in methods of suicide attempts. Medical science monitor. 17(8), PH65-70.

80. Turecki, G., Brent D.A. 2016. Suicide and suicidal behaviour. Lancet. 387(10024), 1227-1239.

81. Turner, H. A., Finkelhor, D., Shattuck, A., Hamby, S. 2012. Recent victimization exposure and suicidal ideation in adolescents. Archives of pediatrics \& adolescent medicine. 166(12), 1149-1154.

82. Turunen, J. 2013. Family Structure, Gender, and Adolescent Emotional WellBeing. Journal of Divorce \& Remarriage. 54(6), 476-504.

83. Velika, B., Pudule, I., Grīnberga, D., Springǵe, L., Gobiņa, I. 2012. 2011. gada pētījums par Latvijas jauniešu bērnībā gūto nelabvēlīgo pieredzi. Rīga: Slimību profilakses un kontroles centrs. 
84. Vijayakumar, L. 2015. Suicide in women. Indian Journal of Psychiatry. 57(Suppl 2), S233-S238.

85. Vingilis, E. R., Wade, T. J., Seeley, J. S. 2002. Predictors of adolescent self-rated health. Analysis of the National Population Health Survey. Canadian journal of public health. 93(3), 193-197.

86. Wagner, B. M., Cole, R. E., Schwartzman, P. 1995. Psychosocial correlates of suicide attempts among junior and senior high school youth. Suicide \& lifethreatening behavior. 25(3), 358-372.

87. Waldrop, A. E., Hanson, R. F., Resnick, H. S., Kilpatrick, D. G., Naugle, A. E., Saunders, B. E. 2007. Risk factors for suicidal behavior among a national sample of adolescents: implications for prevention. Journal of traumatic stress. 20(5), 869-879.

88. Wallen, J., Rubin, R. H. 1997. The role of the family in mediating the effects of community violence in children. Aggression and violent behavior. 2(1), 33-41.

89. Wang, J., Hughes, J., Murphy, G. T., Rigby, J. A., Langille, D.B. 2003. Suicidal behaviours among adolescents in northern Nova Scotia. Canadian journal of public health. 94(3), 207-211.

90. Wang, J., Iannotti, R. J., Luk, J. W., Nansel, T. R. 2010. Co-occurrence of victimization from five subtypes of bullying: physical, verbal, social exclusion, spreading rumors, and cyber. Journal of pediatric psychology. 35(10), 1103-1112.

91. Wang, P. W., Yen, C. F. 2017. Adolescent substance use behavior and suicidal behavior for boys and girls: a cross-sectional study by latent analysis approach. BMC psychiatry. 17(1), 392.

92. Wild, L. G., Flisher, A. J., Lombard, C. 2004. Suicidal ideation and attempts in adolescents: associations with depression and six domains of self-esteem. Journal of Adolescence. 27(6), 611-624.

93. Wolitzky-Taylor, K. B., Ruggiero, K. J., McCart, M. R., Smith, D. W., Hanson, R. F., Resnick, H. S., de Arellano, M. A., Saunders, B. E., Kilpatrick, D. G. 2010. Has Adolescent Suicidality Decreased in the United States? Data from Two National Samples of Adolescents Interviewed in 1995 and 2005. Journal of clinical child and adolescent psychology. 39(1), 64-76.

94. World Health Organization. 2008. Preventing suicide: a resource for media professionals. Geneva: World Health Organization.

95. World Health Organization. 2013. Mental Health Action Plan 2013 - 2020. In: World Health Organization. Available from: https://www.who.int/iris/bitstream/10665/89966/1/9789241506021_eng.pdf?ua=1 [accessed on 28.06.2018]

96. World Health Organization. 2014a. Preventing suicide: a global imperative. Luxembourg: World Health Organization.

97. World Health Organization. 2014b. Suicide prevention: A resource for non-fatal suicidal behaviour case registration. Geneva: World Health Organization.

98. World Health Organization. 2015. The European Mental Health Action Plan 2013 - 2020. In: World Health Organization. Available from: http://www.euro.who.int/_data/assets/pdf_file/0020/280604/WHO-EuropeMental-Health-Acion-Plan-2013-2020.pdf [accessed on 28.06.2018]

99. World Health Organization. 2016. Growing up unequal: gender and socioeconomic differences in young people's health and well-being: Health 
Behaviour in School-aged Children (HBSC) study, international report from the 2013/2014 survey. Copenhagen: World Health Organization Regional Office for Europe.

100. World Health Organization. 2017. Global Accelerated Action for the Health of Adolescents (AA-HA!): guidance to support country implementation. Geneva: World Health Organization.

101. World Health Organization. 2018a. Suicide data. In: World Health Organization Mental health.

Available

from:

www.who.int/mental_health/prevention/suicide/suicideprevent/en/ [accessed on 28.06.2018]

102. World Health Organization. 2018b. Mental Health Atlas 2017. Geneva: World Health Organization.

103. Wu, P., Hoven, C.W., Liu, X., Cohen, P., Fuller, C.J., Shaffer, D. 2004. Substance use, suicidal ideation and attempts in children and adolescents. Suicide \& lifethreatening behavior. 34(4), 408-420.

104. Zaborskis, A., Sirvyte, D., Zemaitiene, N. 2016. Prevalence and familial predictors of suicidal behaviour among adolescents in Lithuania: a cross-sectional survey. 2014. BMC Public Health. 16:554. Available from: doi: 10.1186/s12889-0163211-x [accessed on 01.08.2018].

105. Zarrouq, B., Bendaou, B., Elkinany, S., Rammouz, I., Aalouane, R., Lyoussi, B., Khelafa, S., Bout, A., Berhili N., Hlal, H., Nejjari, C., El Rhazi, K. 2015. Suicidal behaviors among Moroccan school students: prevalence and association with socio-demographic characteristics and psychoactive substances use: a crosssectional study. BMC Psychiatry. 15:284. Available from: doi:10.1186/s12888015-0680-x [accessed on 16.07.2018].

106. Zhang, J., Tong, H. Q., Zhou, L. 2005. The effect of bereavement due to suicide on survivors depression: a study of chinese samples. Omega. 51(3), 217-227.

107. Zhang, Z. 2016. Model building strategy for logistic regression: purposeful selection. Annals of translational medicine. 4(6), 111.

108. Zubrick, S. R., Hafekost, J., Johnson, S. E., Lawrence, D., Saw, S., Sawyer, M., Ainley, J., Buckingham, W. J. 2016. Suicidal behaviours: Prevalence estimates from the second Australian Child and Adolescent Survey of Mental Health and Wellbeing. Australian \& New Zealand Journal of Psychiatry. 50(9), 899-910.

109. Zubrick, S. R., Hafekost, J., Johnson, S. E., Sawyer, M. G., Patton, G., Lawrence, D. 2017. The continuity and duration of depression and its relationship to nonsuicidal self-harm and suicidal ideation and behavior in adolescents 12-17. Journal of affective disorders. 220, 49-56. 


\section{PUBLIKĀCIJAS UN TĒZES PAR DARBA TĒMU}

\section{Raksti starptautiski recenzētos žurnālos}

1. Springe, L., Pulmanis, T., Velika, B., Pudule, I., Grīnberga, D., Villeruša, A. 2016. Self-reported suicide attempts and exposure to different types of violence and neglect during childhood: Findings from a young adult population survey in Latvia. Scandinavian Journal of Public Health. 44, 411-417.

2. Rancāns, E., Pulmanis, T., Sprinğge, L., Velika, B., Pudule, I., Grīnberga, D. 2015. Prevalence and sociodemographic characteristics of self-reported suicidal behaviours in Latvia in 2010: A population-based study. Nordic Journal of Psychiatry. 70(3), 195-201.

\section{Raksti Latvijā recenzētos žurnālos}

1. Pulmanis, T., Trapencieris, M., Springe, L., Taube, M. 2015. Pusaudžu pašnāvnieciskā uzvedība Latvijā: pašnāvības plānu sakarība ar ġimeni, vienaudžiem un skolu saistītiem faktoriem. Rīgas Stradinna universitātes zinātniskie raksti 2014. Rīga: Rīgas Stradiṇa universitāte

2. Pulmanis, T., Trapencieris, M., Sprinğge, L., Taube, M. 2014. Pusaudžu pašnāvnieciskā uzvedība Latvijā: sakarības ar atkarību izraisošo vielu lietošanu. Rīgas Stradiña universitātes zinātniskie raksti 2013. Rīga: Rīgas Stradiṇa universitāte

3. Pulmanis, T., Springée, L., Trapencieris, M., Taube, M. 2013. Pašnāvnieciskās uzvedības mūža prevalence un tās izmainas dinamikā 1516 gadus veciem pusaudžiem dzimumu grupās Latvijā. Rìgas Stradiṇa universitātes zinātniskie raksti 2012. Rīga: Rīgas Stradiņa universitāte

4. Pulmanis, T., Taube, M, Pulmane, K., Trapencieris, M. 2012. Ģimenes, vardarbības un psihoemocionālo faktoru sakarības ar pašnāvības mēginājumiem 13-18 gadus vecu skolēnu vidū. Rīgas Stradiṇa universitātes zinātniskie raksti 2011. Rīga: Rīgas Stradiṇa universitāte 
5. Skrule, J, Pulmanis T., Taube, M, Briğis, G. 2010. Alkohola lietošana un suicidālās tieksmes skolēnu vidū. Rīgas Stradinna universitātes zinātniskie raksti 2009. Rīga: Rīgas Stradiņa universitāte

\section{Tēzes starptautiskās konferencēs}

1. Pulmanis, T., Springge, L., Taube, M., Millere, I. 2019. Adolescent SelfReported Lifetime Gender-Specific Suicidal Ideation in Latvia: Association with Peer-Related Factors. Rìga Stradiňs University International Conference on Medical and Health Care Sciences: Knowledge for Use in Practice. Abstracts, 675.

2. Rancans, E., Pulmanis, T., Kivite, A. 2017. Suicides and Suicidal Behaviours in $21^{\text {st }}$ Century in Latvia. WPA Inter Zonal Congress Electronic Abstract Book. Vilnius, Lithuania.

3. Pulmanis, T., Springe, L., Sile, L., Trapencieris, M., Taube, M. 2014. Association between adolescent self-reported lifetime suicide attempts and use of synthetic cannabinoids and other addictive substances in Latvia. Abstract book, 15 th European Symposium On Suicide and Suicidal Behaviour. Tallinn, Estonia.

4. Springe, L., Pulmanis, T., Pudule, I., Grinberga, D., Velika, B.,Villerusa, A. 2014. Association between exposure to physical and emotional neglect in childhood and self-reported lifetime suicide attempts in Latvian youth. Abstract book, 15 th European Symposium On Suicide and Suicidal Behaviour. Tallinn, Estonia.

5. Springe, L., Villerusa, A., Pulmanis, T., Pudule, I., Grinberga, D., Velika, B. 2013. Association between exposure to family violence in childhood and self-reported lifetime suicide attempts in Latvian youth. European Journal of Epidemiology. 28, Supplement 1, S213.

6. Pulmanis, T., Trapencieris, M., Taube, M. 2013. Adolescent self-reported lifetime suicide attempts in Latvia: family related factors. Atencion Primaria, 45, 123. 
7. Pulmanis, T., Trapencieris, M., Taube, M. 2012. Adolescent SelfReported Lifetime Suicidal Behaviours in Latvia. Youth in Latvia, Europe, Globe: Opportunities and Risks. Abstracts, 53.

\section{Tēzes konferencēs Latvijā}

1. Pulmanis, T., Trapencieris, M., Taube, M. 2014. Pusaudžu pašnāvnieciskā uzvedība Latvijā: pašnāvības plānu sakarības ar gimeni, vienaudžiem un skolu saistītiem faktoriem. 2014. gada Zinātniskās konferences tēzes. Rīga: Rīgas Stradiña universitāte.

2. Pulmanis, T., Trapencieris, M., Taube, M. 2013. Pusaudžu pašnāvnieciskā uzvedība Latvijā: Sakarības ar atkarību izraisošo vielu lietošanu. 2013. gada Zinātniskās konferences tēzes. Rīga: Rīgas Stradiṇa universitāte.

3. Pulmanis, T., Taube, M., Trapencieris, M., Vegnere, M. 2012. Pašnāvniecisko tieksmju prevalence 15-16 gadus veciem pusaudžiem Latvijā. 2012. gada Zinātniskās konferences tēzes. Rīga: Rīgas Stradiṇa universitāte. 


\section{PATEICĪBAS}

Patiesā cieņā vēlos izteikt visdziḷāko pateicību mana promocijas darba vadītājam - psihiatram un profesoram Mārim Taubem par veiksmīgo sadarbību, atbalstu un mudināšanu tiekties uz mērḳi ne tikai promocijas darba izstrādes laikā, bet arī agrākos studiju posmos un karjeras attīstībā.

Izsaku pateicību Slimību profilakses un kontroles centra direktorei Ivetai Gavarei, Atkarības slimību riska analīzes nodaḷas vadītājai Aijai Pelnei un kolēgiiem gan par iespēju izmantot ESPAD datu bāzi promocijas darba izstrādē, gan par manas personīgās profesionālās izaugsmes attīstību arvien jaunu mērķu sasniegšanai.

Īpašs paldies Mārcim Trapencierim par padziḷinātas intereses radīšanu, apmācību un nozīmīgiem padomiem darbā ar datiem un datu apstrādes metodēm.

Tāpat sirsnīgs paldies Sabiedrības veselības un sociālās labklājības fakultātes dekānei, profesorei Ingai Millerei par aktīvu motivēšanu, atbalstu un atbalstošu apstākḷu veicināšanu sekmīgai promocijas darba izstrādei.

Īpašu pateicību vēlos izteikt arī kolēgei un draugam, Sabiedrības veselības un epidemiologijas katedras docentei Laumai Springégei par nesavtīgo praktisko un emocionālo atbalstu promocijas darba izstrādes laikā, kā arī citiem katedras kolēgiem par palīdzību un atbalstu.

Sirsnīgs paldies arī manai ǵimenei un draugiem par ticību, iedrošinājumu, atbalstu un sapratni. 